\title{
Airway Redox Homeostasis and Inflammation Gone Awry: From Molecular Pathogenesis to Emerging Therapeutics in Respiratory Pathology
}

\author{
Javier Checa and Josep M. Aran *(i) \\ Immune-Inflammatory Processes and Gene Therapeutics Group, IDIBELL, L'Hospitalet de Llobregat, \\ 08908 Barcelona, Spain; jcheca@idibell.cat \\ * Correspondence: jaran@idibell.cat; Tel.: +34-93-2607428; Fax: +34-93-2607414
}

Received: 20 November 2020; Accepted: 5 December 2020; Published: 7 December 2020

\begin{abstract}
As aerobic organisms, we are continuously and throughout our lifetime subjected to an oxidizing atmosphere and, most often, to environmental threats. The lung is the internal organ most highly exposed to this milieu. Therefore, it has evolved to confront both oxidative stress induced by reactive oxygen species (ROS) and a variety of pollutants, pathogens, and allergens that promote inflammation and can harm the airways to different degrees. Indeed, an excess of ROS, generated intrinsically or from external sources, can imprint direct damage to key structural cell components (nucleic acids, sugars, lipids, and proteins) and indirectly perturb ROS-mediated signaling in lung epithelia, impairing its homeostasis. These early events complemented with efficient recognition of pathogen- or damage-associated recognition patterns by the airway resident cells alert the immune system, which mounts an inflammatory response to remove the hazards, including collateral dead cells and cellular debris, in an attempt to return to homeostatic conditions. Thus, any major or chronic dysregulation of the redox balance, the air-liquid interface, or defects in epithelial proteins impairing mucociliary clearance or other defense systems may lead to airway damage. Here, we review our understanding of the key role of oxidative stress and inflammation in respiratory pathology, and extensively report current and future trends in antioxidant and anti-inflammatory treatments focusing on the following major acute and chronic lung diseases: acute lung injury/respiratory distress syndrome, asthma, chronic obstructive pulmonary disease, pulmonary fibrosis, and cystic fibrosis.
\end{abstract}

Keywords: oxidative stress; inflammation; respiratory diseases; therapeutic strategies

\section{Introduction}

Due to its continuously exposed surface to the external environment, the lung exhibits a formidable defense system constituted by a high number of interacting mechanisms [1,2]. First, anatomical retention features such as the nasopharyngeal barrier filter particles or microorganisms higher than 2-3 $\mu \mathrm{m}$ [3-5]. Secondly, there are systems to expel the external elements, i.e., the cough [6], and the mucociliary system [7]. Whether or not the external and potentially harmful particles overcome these mechanisms, the humoral factors come into play, including bactericidal and antiviral secretions (mucins, defensins, lactoferrin, complement factors, etc.) [8,9], and cellular factors of the innate [10] and adaptive immune system. These include the airway epithelial cells [11]; the phagocytic cells that, in turn, comprise polymorphonuclear (PMN) cells such as neutrophils (the most abundant immune cell type) [12] or eosinophils [13]; monocytes and macrophages [14,15]; natural killer cells (NKC) [16]; mastocytes [17]; and dendritic cells [18]. All these cells recognize pathogen-associated molecular patterns (PAMPs) such as lipopolysaccharide (LPS) through pattern recognition receptors (PRRs) [19], and Toll-like 
receptors (TLR) are the most studied [20]. Their stimulation triggers the activation of antimicrobial genes and inflammatory cytokines and chemokines, as well as the direct response against antigens [21], activating the adaptive immune system, namely B and T lymphocytes [22,23].

Nevertheless, when one or several components of this intricate network of pulmonary defense mechanisms fail, homeostasis is disrupted, and respiratory pathology ensues causing oxidative stress and inflammation. This review briefly underscores the molecular mechanisms behind environmental stress (airborne pollutants, pathogens, and allergens) causing pulmonary immune-inflammatory responses and focuses on current pharmacological options, emerging, and promising therapeutic approaches and new investigational treatments targeting the most common acute and chronic respiratory illnesses.

\section{Reactive Oxygen Species Production in the Airways}

Environmental pollutants such as ozone $\left(\mathrm{O}_{3}\right)$ and nitrogen dioxide $\left(\mathrm{NO}_{2}\right)$ react with several molecules at the respiratory surface and generate secondary reactive oxygen species (ROS) such as superoxide radicals $\left(\mathrm{O}_{2}{ }^{--}\right)$, hydrogen peroxide $\left(\mathrm{H}_{2} \mathrm{O}_{2}\right)$, and hydroxyl radicals $\left(\mathrm{OH}^{\cdot}\right)[24,25]$. Additionally, lung cells generate ROS as by-products of aerobic metabolism involving enzymatic reactions in the mitochondrial electron transport chain (e.g., through activity of amine oxidases, $\alpha$-ketoglutarate dehydrogenase $(\alpha-\mathrm{KGDH})$, and pyruvate dehydrogenase (PDH), and activation of the p66shc adaptor protein) [26-28]. Furthermore, ROS can be produced in peroxisomes [29], or by cytochrome P450 enzymes, cyclooxygenases, and lipoxygenases [30]. Nitric oxidase synthases (NOS) expand the spectrum of ROS producing reactive nitrogen species $\left(\mathrm{NO}_{2}\right.$ or $\left.\mathrm{ONOO}^{-}\right)$[31]. ROS are also produced as mediators of biological functions, with a role in inflammatory processes involving epithelial and endothelial cells, alveolar macrophages, and granulocytes [32,33]. NADPH oxidases (NOX) enzymes are involved in both bacterial killing and regulation of inflammatory mediators [34]. Indeed, dual oxidases, DUOX1 and DUOX2, the major isoform of NOX, are expressed preferentially in the respiratory epithelium [35-37].

\section{Respiratory Surface: Antioxidant Defenses}

The air-liquid interface covering the developed airways is an environment subjected to continuous oxidative stress. Accordingly, the respiratory epithelium is exposed to endogenous and also to environmental ROS. Therefore, it expresses a variety of antioxidant enzymes. Superoxide dismutases such as SOD3 (an extracellular SOD, EC-SOD) [38-40], highly-expressed in the lung at the extracellular matrix and at the cell surfaces [41], generate $\mathrm{H}_{2} \mathrm{O}_{2}$ which is detoxified by other enzymes. Catalase, decomposes $\mathrm{H}_{2} \mathrm{O}_{2}$ into $\mathrm{H}_{2} \mathrm{O}$ and $\mathrm{O}_{2}$, predominantly within alveolar macrophages and type II epithelial cells $[42,43]$. Glutathione (GSH) peroxidase (GPX) catalyzes the reduction of $\mathrm{H}_{2} \mathrm{O}_{2}$ or other peroxides to glutathione disulfide (GSSG) and $\mathrm{H}_{2} \mathrm{O}$, of which GPX1 is thought to be responsible for $95 \%$ of overall lung tissue GPX activity [44]. Peroxiredoxins (PRX), with all six mammalian family members expressed in different compartments within the lung [45], particularly PRX I, III, V, and VI in the bronchial epithelium, PRX V and VI in the alveolar epithelium, and PRX I and III in alveolar macrophages, decompose $\mathrm{H}_{2} \mathrm{O}_{2}$ and protect against oxidative stress [46-48]. Thioredoxin (TRX), whose main antioxidant role is related to its ability to regenerate oxidized forms of PRX [49,50], catalyzes the reduction of disulfide bonds, modulates signal transduction pathways, and has anti-inflammatory properties [51,52]. Finally, glutaredoxins (GRX) participate in the reduction of oxidative modifications involving GSH [53,54].

The following small non-enzymatic low-molecular-weight antioxidant molecules are highly relevant: ascorbic acid (vitamin C) [55], uric acid [56], GSH [57,58], and $\alpha$-tocopherol (vitamin E) [59]. These non-enzymatic molecules are the most prominent antioxidants reacting with reactive oxidant gases such as $\mathrm{O}_{3}$ and $\mathrm{NO}_{2}$ [60-63] and with the secondary oxidants generated by them, which can increase the oxidative injury [64]. Furthermore, the enzymatic antioxidants complement the function of these small molecules. Nuclear factor erythroid 2-related factor (Nrf2) regulates the transcription of 
both antioxidant genes coding for many of the above-highlighted enzymes and phase II detoxification genes [65-68].

\section{Inflammation and Oxidative Stress in Pulmonary Diseases}

A variety of immune and non-immune cells are activated during an inflammatory process. Each cell type releases cytokines and mediators that modify the activities of other cells, inducing an inflammatory network that progresses and resolves towards healthy homeostatic, or pathological outcomes. The lung is a vital organ for gas exchange and is constantly exposed to harmful airborne pathogens. Therefore, an immediate and intense protective/defensive inflammatory action is required to eliminate the invaders as early as possible. Nevertheless, excessive inflammation can be life threatening [1]. Consequently, a delicate balance between inflammation and anti-inflammation is essential for lung homeostasis and for the prevention of chronic inflammation [69]. Among the main inflammatory mediators involved in the pathogenesis of respiratory diseases are biochemical mediators such as histamine, thrombin, complement anaphylatoxins, prostaglandins, nitric oxide (NO), and molecules induced by oxidative stress [70]. These compounds mediate cell signaling and enhance cytokine production, among other activities.

Thus, airborne toxicants stimulate local ROS production inducing protein oxidation, lipoxidation, glycation end products, and DNA damage, and leading to mitochondrial dysfunction, cell death, the recruitment of inflammatory cells (mainly macrophages and neutrophils), profibrotic changes or mucus hypersecretion. These oxidative stress-mediated cellular processes drive the development of key environmental respiratory diseases such as acute lung injury/respiratory distress syndrome, asthma, chronic obstructive pulmonary disease, and pulmonary fibrosis, and affect the progression of the most common hereditary disease affecting the lung, i.e., cystic fibrosis.

\subsection{Acute Pulmonary Inflammation}

Acute Lung Injury (ALI) and Acute Respiratory Distress Syndrome (ARDS)

Acute respiratory distress syndrome (ARDS) and its milder form acute lung injury (ALI) are critical pulmonary dysfunctions caused by heterogeneous pathologic factors [71] involving acute development of respiratory failure and severe hypoxemia [72-74], bilateral diffuse lung infiltrations, and impaired alveolar liquid clearance [75]. Lung injury leads to pulmonary vascular permeability, increased production of proinflammatory factors and enhanced expression of the adhesion molecules necessary for leukocyte recruitment and neutrophil migration across the endothelial layer [76,77]. Activated neutrophils secrete cytotoxic agents such as granular enzymes, proinflammatory cytokines, bioactive lipids, and along with epithelium and endothelium, excessive ROS [78], which upregulate the expression of proinflammatory cytokines and adhesion molecules amplifying the tissue damage and pulmonary edema $[79,80]$. Furthermore, a priority upon initiation of mechanical ventilation for ALI patients is providing them $100 \% \mathrm{FiO} 2$ (fraction of inspired oxygen). Nevertheless, protecting against hypoxemia may predispose to oxidative stress, which may be further enhanced by decreased levels of GSH [81].

ARDS treatment has not experienced significant advances in the last 50 years. Early detection is the best approach to attenuate the development of ALI/ARDS. Therefore, several imaging techniques (ultrasound, CT scan, and positron emission tomography) are being assessed for the diagnosis of capillary permeability edema in early phase ARDS, indicative of damage to the alveolar-capillary membrane, given the poor sensitivity of chest X-rays [82-86]. There is no efficient therapy available, although mechanical lung ventilation has long been applied as a supportive approach for healing lung oxygenation, supplemented by anti-inflammatory drugs. Corticosteroid therapy was first indicated for ARDS by Ashbaugh and colleagues [73]. Indeed, despite its relevant side effects, low-dose and extended steroid treatment seems to improve pulmonary physiology in ARDS patients [87]. Other traditional 
treatments are fluid and hemodynamic management [88] to decrease pulmonary edema. The objective is to maintain the lowest intravascular volume.

\subsection{Chronic Pulmonary Inflammation}

\subsubsection{Asthma}

Asthma is a chronic inflammatory disorder of the airways in which gene-environment interactions involving a variety of cell types play an important role [89,90], although its overall pathogenesis remains unknown. The inflammatory response in asthma consists of the recognition of allergen patterns by TLRs [91]. Most asthmatics have type 2 inflammation, related to the presence of type 2 cytokines (interleukins IL-4, IL-5, and IL-14) and a variety of inflammatory cells (eosinophils, mast cells, basophils, type $2 \mathrm{~T}$ helper (Th2) lymphocytes, immunoglobulin E (IgE)-producing plasma cells, epithelial cells, and macrophages) [92]. Myeloid dendritic cells process allergens and release chemokine (C-C motif) ligands CCL17 and CCL22 to attract Th2 cells to the injured region [93]. IgE molecules sensitize mast cells to release cysteinyl leukotrienes (CysLTs) and prostaglandin D2 (PGD2) [94]. Damaged epithelial cells release CCL11 to recruit eosinophils, which attract more proinflammatory mediators [95]. Eosinophils also produce pro-resolving lipid mediators (PD1) and these stimulate IL-10 production and macrophage phagocytosis, promoting the resolution of inflammation [96]. Damaged epithelial cells release stem cell factor (SCF) to activate myofibroblasts to repair damaged epithelial cells. Airway epithelial cells also play a relevant role regulating type 2 inflammation via cytokines (IL-25, IL-33, and thymic stromal lymphopoietin) [92].

Oxidative stress is important in asthma [97,98]. Steroid therapy attenuates $\mathrm{H}_{2} \mathrm{O}_{2}$ [99], oxidative stress markers [100] and NO levels [101]. An increase in ROS production is inversely correlated with forced expiratory volume in $1 \mathrm{~s}$ (FEV1) [102]. Therefore, inflammation in asthma results in increased oxidative stress in the airways [103], in alveolar macrophages, and in eosinophils and neutrophils [104], associated with damage to a wide range of biologic molecules such as lipids and proteins $[105,106]$. Numerous cytokines such as tumor necrosis factor alpha (TNF- $\alpha$ ), heparin-binding epidermal growth factor (HB-EGF), fibroblast growth factor 2 (FGF2), angiotensin II (AII), serotonin, and thrombin are found in the lung during inflammation and activate oxidases that lead to increased ROS in cell culture [107]. ROS decrease $\beta$-adrenergic function in the lung [108] and, consequently, airway hyperresponsiveness is produced by increasing the vagal tone due to damage to oxidant-sensitive beta-adrenergic receptors [109]. ROS also sensitize airway muscles to acetylcholine-induced contraction $[110,111]$ and produce bronchial hyperactivity [112], promote histamine release from mast cells, and increase mucus secretion from airway epithelial cells [113]. Furthermore, ROS prompt endothelial barrier dysfunction through tight junctions disruption, which increases the permeability to fluid, inflammatory cells, and mediators [114,115], decrease numbers and function of epithelial cilia [116], and stimulate mucin secretion [117]. In addition, $\mathrm{H}_{2} \mathrm{O}_{2}$ activates mitogen-activated kinases (MAPKs) in tracheal myocytes [118] and stimulates the tracheal smooth muscle to contract [119-121].

Regarding antioxidant defenses, despite increased levels of GSH in the airways, the ratio of oxidized to reduced GSH also increases [57]. Other antioxidants such as ascorbate and alpha-tocopherol decrease [122,123], and SOD activity, but not SOD quantity [39], is likewise diminished [124-129]. Catalase activity is suppressed $[130,131]$. GPX1 can also promote both proinflammatory cytokine production and neutrophilia in response to LPS challenge [132], and ovalbumin-induced allergic asthma. In fact, GPX1 regulates T helper cell proliferation and differentiation toward Th2 and Th17 phenotypes [133]. Likewise, GPX3 is elevated in asthmatic airways through oxidant-induced activation of activator protein 1 (AP-1) [134,135]. Increased extracellular levels of TRX have been reported as well [136,137], indicating increased oxidative stress [49]. Lung tissue expression of GRX-1 is increased in models of allergic asthma $[138,139]$. Several reports have shown that GRX-1 mediates proinflammatory signaling in LPS-mediated lung inflammation or during allergic airways disease, possibly by regulating S-glutathionylation of nuclear factor kappa-light-chain-enhancer of activated B cells (NF- $\mathrm{kB}$ ) or other 
proinflammatory signaling pathways [138-140], although its importance in regulating smoking-induced lung inflammation and injury is less clear [141-143]. Additionally, during the progress of chronic pulmonary diseases such as chronic obstructive pulmonary disease (COPD) or asthma, alteration of the redox homeostasis leads to dysregulation of Nrf2 and defective antioxidant signaling [144-146].

Considering treatments, among the traditional treatments are inhaled corticosteroids (ICS) $[147,148]$. These reduce inflammation by modulating NF-KB and AP-1 expression, and are effective preventing oxidative stress $[149,150]$. In new onset untreated persistent asthma, low-dose inhaled budesonide reduces asthma exacerbations by almost 50\% [151], and ICS can reduce the number of airway eosinophils [152-154]. A combination of ICS and long-acting $\beta 2$-agonists (LABAs) (e.g., budesonide and formoterol) significantly reduces asthma exacerbations compared with ICS alone [155]. Alternative treatments are antileukotrienes [156], the anticholinergic tiotropium [157], and environmental control [158].

Nevertheless, even in patients with well controlled asthma, exacerbations occur. Inhaled or nebulized short-acting $\beta 2$-agonists (SABAs), such as albuterol or levalbuterol, provide rapid relief of symptomatic asthma [159]. Adding the short-acting anticholinergic ipratropium bromide to the inhaled SABA albuterol in severe exacerbations improves lung function and decreases rates of hospitalization [159-161]. Moreover, several studies have assessed ICS and oral corticosteroids (OCS) during moderate or severe acute asthma exacerbations. However, the evidence for the efficacy of these agents remains controversial because of significant safety concerns and weak outcomes $[148,162,163]$.

\subsubsection{Chronic Obstructive Pulmonary Disease (COPD)}

COPD is mainly initiated by inhalation of cigarette smoke, which induces oxidative damage to lung epithelial cells, leading to the development of a chronic persistent inflammatory response from the peripheral airways to the lung parenchyma [164]. Cigarette pollutants, through PRRs such as TLRs and purinergic receptors, and damage-associated molecular patterns (DAMPs) released by apoptotic or necrotic cells, readily initiate pattern recognition [165]. This is followed by the local buildup of chemotactic factors, which attract inflammatory cells to the injured region [166-168]. Macrophages, epithelial cells, and infiltrated inflammatory cells release, on the one hand, proteases such as matrix metalloproteinase 9 (MMP9), resulting in elastin degradation and emphysema $[169,170]$. Thereby the immune system switches to a Th17 response to promote inflammation [171,172] and, on the other hand, also secretes transforming growth factor- $\beta$ (TGF- $\beta$ ), a pleiotropic cytokine that triggers tissue remodeling and fibrosis $[173,174]$. Furthermore, the airway smooth muscle produces inflammatory cytokines, proteases, and growth factors, which are essential in the remodeling process and induce structural and functional changes in the airways [175].

ROS directly damage biological molecules and lung extracellular matrix, leading to cell dysfunction or death, and activate NF- $\mathrm{KB}$, which enhances the expression of inflammatory genes such as IL- 8 and TNF- $\alpha$, important in COPD, contributing to reversible airway narrowing [176]. Neutrophils show increased oxide anion $\left(\mathrm{O}_{2}^{-}\right)$levels [177], and lipid peroxidation products such as thiobarbituric acid (TBA), linoleic acid (LA), and F2-isoprostane are also increased [178]. Conversely, the plasma antioxidant capacity is decreased [179]. Oxidative stress contributes to a proteinase-anti-proteinase imbalance, both by inactivating anti-proteinases such as $\alpha 1$-antitrypsin (A1AT) and secretory leukocyte proteinase inhibitor, and by activating MMPs $[180,181]$. As occurs in asthma, GSH levels are decreased and hold a more oxidized state [182]. In contrast, lung SOD2 levels are increased in response to hyperoxia and inflammatory cytokines [183]. Genetic studies have shown that SOD3 is associated with lung function and the development of COPD [184-186]. TRX may be reduced in COPD [187]. Increased levels of extracellular GRX-1 have also been reported in the lung and sputum of asthma and COPD patients $[139,188]$, although its relevance regulating smoking-induced lung inflammation and injury is still unclear [141,142]. Likewise, induction of Nrf2-mediated antioxidant gene expression seems to be flawed $[144,189]$. 
Historical treatments for COPD have primarily focused on long-term oxygen therapy and restoring pulmonary function by tackling the underlying inflammation and bronchoconstriction causing air flow obstruction (shortness of breath, cough, chest tightness, and mucus production) [190]. Guidelines recommend the use of long-acting bronchodilators such as LABAs, with or without ICS, or long-acting anticholinergics, and, in severe exacerbations, the addition of phosphodiesterase inhibitors, including roflumilast [191]. Oral corticosteroids are often used in patients that fail to respond to these therapies.

\subsubsection{Pulmonary Fibrosis}

Pulmonary fibrosis is the outcome of a diverse group of lung insults including toxins, fibers/particles, autoimmune reactions, drugs, and radiation. Nevertheless its primary etiology is unknown and in most cases is referred to as idiopathic pulmonary fibrosis (IPF) [192]. Aberrant epithelial-mesenchymal crosstalk is the main hallmark of IPF, although the immune-inflammatory process plays an important role in all stages of fibrosis. Neutrophil accumulation is a characteristic feature of alveolitis $[193,194]$, leading to persistent injury, tissue remodeling and fibrosis, possibly through the release of proteases such as elastase. Macrophages initially secrete proinflammatory cytokines and later recruit fibroblasts, epithelial and endothelial cells, participating in the reparative environment. M2 macrophages seem to play a key role regulating fibrosis [195]. In fact, the risk for IPF acute exacerbations seems to be reflected by M2 cytokine production levels [196]. Monocytes also play a key role during fibrogenesis; they serve as precursor cells for pro-fibrotic macrophages and fibrocytes $[197,198]$, become highly activated during fibrotic conditions, and their presence correlates directly with the extent of fibrosis in the lungs [199]. Fibrocytes are circulating mesenchymal progenitor cells that contribute to fibroblast activation, extracellular matrix production, and other paracrine functions, leading to tissue remodeling and ongoing fibrosis [200,201]. Furthermore, recent studies have suggested that type 2 innate lymphoid cells (ILC2) communicate with mast cells to release mediators that are able to modulate the disease rather than its pathogenesis [202,203]. Regarding the adaptative immune system, $\mathrm{T}$ cells are widely present in active-disease regions and pulmonary tertiary lymphoid organs (TLOs) in patients with IPF [204-206]. A Th1/Th2 immune response imbalance has been considered essential in IPF pathogenesis. Certainly, Th2 cytokines promote pro-fibrotic responses, whereas Th1 cytokines (IFN $\gamma$ and IL-12) may be protective [207-211]. Historically, it has been thought that regulatory T cells (Tregs) had a protective role in IPF because of their anti-inflammatory and anti-fibrocyte accumulation activities. Nevertheless, recent studies have indicated that the role of Tregs differed among the distinctive stages of fibrosis. Indeed, Tregs seem also to secrete pro-fibrotic cytokines [212].

Tilting the balance between oxidant production and antioxidant protection towards the former leads to ROS accumulation, which is promoted by fibrotic stimuli of unidentified origin [213,214]. In fact, oxidants may contribute to the occurrence of pulmonary fibrosis because of their effects on the secretion of cytokines and growth factors such as TGF- $\beta[215,216]$. TGF- $\beta$ induces ROS production by activation of NOX (e.g., NOX4) [217-219] or mitochondrial dysfunction. It also reduces the expression of both catalase and SOD2, and thereby decreases natural cellular antioxidant production [220-223]. Human subjects with IPF have shown increased levels of oxidized proteins [211,224]. As in asthma and COPD, GSH levels are often suppressed and occur in a more oxidized state [225]. Animal studies in mice have demonstrated a protective role of SOD3 in models of interstitial lung disease, including bleomycin-induced pulmonary fibrosis [226-229], which have been confirmed in patients [230]. TRX expression is also upregulated in pulmonary fibrosis and interstitial lung disease [231,232].

There has been no evidence for an effect of corticosteroid treatment in patients with IPF [233]. In addition, $\mathrm{N}$-acetylcysteine, either alone or with azathioprine and prednisone, offered no significant benefit and was even detrimental [234,235]. In the last years, two anti-fibrotic drugs have been introduced for IPF treatment: pirfenidone and nintedanib [236-238], and both decrease the progression of the disease and enhance its evolution. In severe disease, the possibility of lung transplantation 
should be considered [239]. For the treatment of persistent hacking cough among people with IPF, dimemorphine phosphate, codeine phosphate, prednisone, or thalidomide are indicated [240]. Low doses of morphine improve the sensation of breathlessness and cough in patients with advanced disease. Among non-pharmacological treatments, home oxygen therapy is feasible in patients with IPF and hypoxemia or respiratory rehabilitation [241].

\subsection{Cystic Fibrosis}

Cystic fibrosis (CF), the most frequent recessive hereditary autosomal disease in the Caucasian population, is caused by mutations in the cystic fibrosis transmembrane conductance regulator (CFTR) gene. Despite the occurrence of multiorgan complications in $\mathrm{CF}$, respiratory failure secondary to chronic lung infection caused by recurrent bacteria and the subsequent inflammation is the most serious outcome of this condition $[242,243]$. Thus, abnormalities in the CFTR chloride $\left(\mathrm{Cl}^{-}\right)$channel at the airway apical surface cause the failure of $\mathrm{Cl}^{-}$secretion and, consequently, sodium $\left(\mathrm{Na}^{+}\right)$hyperabsorption in epithelial cells, dehydrating the airway surface fluid layer, and impairing mucociliary clearance [244-246]. These events support bacterial infection $[247,248]$, which attracts neutrophils (the largest source of ROS) to the site of infection (Figure 1). This infection-inflammation vicious cycle leads to irreversible airway destruction and fibrosis [249]. Although neutrophils, epithelial cells, and their effectors have been most intensely studied, many other cell types, including dendritic cells, $\mathrm{T}$ and B lymphocytes, macrophages, and airway smooth muscle cells produce inflammatory mediators and are actively involved in the host inflammatory response in CF [250].

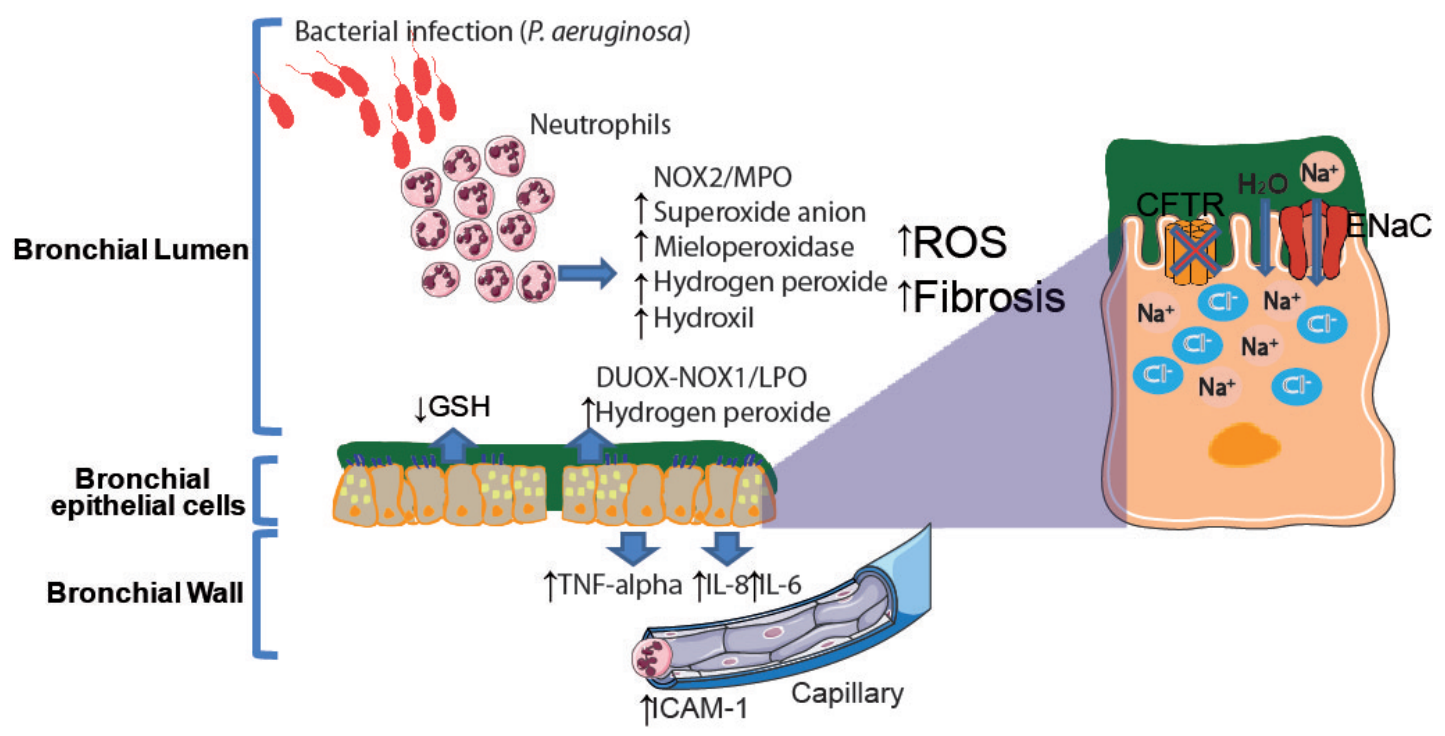

Figure 1. Redox imbalance in the conductive airways of patients affected by cystic fibrosis (CF). Cystic fibrosis transmembrane conductance regulator (CFTR) dysfunction in lungs prevents $\mathrm{Cl}^{-}$secretion and induces $\mathrm{Na}^{+}$hyperabsorption at the airway apical surface, dehydration and impairment of mucociliary clearance. These events favor bacterial infection and prevent its elimination, inducing epithelial cells to secrete proinflammatory cytokines such as IL- 8 and IL-6 and TNF-alpha, which attract neutrophils at the site of infection. As a result, a vicious cycle of neutrophilic inflammation and oxidative stress, produced by the release of large amounts of reactive oxygen species (ROS) both from epithelial cells and neutrophils through DUOX and NOX2, respectively, leads to irreversible airway destruction and fibrosis. Furthermore, low glutathione (GSH) levels further increase the oxidative stress. ROS also increase the migration of neutrophils from capillary venules.

The DUOX/LPO system is engaged by epithelial cells to produce significant quantities of $\operatorname{ROS}\left(\mathrm{H}_{2} \mathrm{O}_{2}\right)$ through two isoforms of NOX expressed in their apical membrane (DUOX 1 and DUOX 2) thought to be related to the CFTR channel [37]. An important function of DUOXs is to support lactoperoxidase (LPO), which is released by caliciform cells of the airways and by the submucosal glands 
to generate bactericidal hypothiocyanite from thiocyanate and $\mathrm{H}_{2} \mathrm{O}_{2}$ [251]. This system is activated continuously and independently of the presence of an open bacterial infection, unlike NOX/MPO [252]. Multiple studies have shown the antimicrobial function of DUOX/ $\mathrm{H}_{2} \mathrm{O}_{2}$ and LPO either against bacteria [253] or viruses [254]. Even mammalian airway epithelial cells might present a novel innate defense mechanism killing bacteria through ROS generation [255]. In CF patients, the level of $\mathrm{NO}$ is reduced, and this is directly related to a deterioration of the pulmonary function $[256,257]$. A sub-optimal antioxidant protection is observed [258]. There are other proteins regulating the $\mathrm{H}_{2} \mathrm{O}_{2}$ levels, such as TRX1, GSTP1, PRDX6 [259], PRDX3 [51], or catalase [260], which are decreased in CF patients. To connect these modifications with CF specific features, a dysfunctional CFTR channel has been found to be associated with a reduced activity of Nrf-2 [261,262].

The presence of a defective CFTR appears to induce a pro-oxidative imbalance in epithelial cells and extracellular fluids of CF airways, which increase the levels of ROS. Constitutive defects on GSH reductase and NOX activities [263-266] together with intestinal malabsorption of fat-soluble antioxidant vitamins (vitamin E and carotenoids) $[267,268]$ could promote a defective antioxidant protection and exacerbate oxidative stress indices, contributing to the progression of the clinical status in CF patients [269-271].

Moreover, ROS activate second messengers through phospholipases A2, C, and D, which induce cytokines and mucin production. Oxidative stress and inflammation can also affect surfactant biophysical activity, leading to early alterations of lung function in patients with CF [272].

Antibiotic treatment has been shown to prevent and control lung infections. These mainly consist of inhaled, nebulized or aerosolized forms of azithromycin, aztreonam and levofloxacin [273-275]. Alternatively, ciprofloxacin, cephalexin, amoxicillin, and doxycycline have also been recommended depending on the sensitivity patterns of the bacterial pathogens [276,277]. Colistin is also used [278]. To control airway inflammation, nonsteroidal anti-inflammatory drugs (NSAIDs) $[279,280]$ and cromoglycate (cromolyn) [281] are used. To reduce the viscoelasticity of bronchial mucus secretions and promote its clearance from $\mathrm{CF}$ lungs, and to dilate the airways, bronchodilators such as inhaled $\beta$-agonists with humidified oxygen, a 3-6\% hypertonic saline solution [282-284], and dornase alfa [285-288] are recommended. Furthermore, exercise [289] and chest physiotherapy including oscillating devices for mucus mobilization is being prescribed as well [290].

\section{Prospective Therapeutic Strategies}

\subsection{ALI/ARDS}

The scientific rationale for emerging therapies in ARDS is to pursue fundamental processes and mediators of its complex pathophysiology [291]. There are emerging therapies in Phase 3 trials assessing the potential benefits of corticosteroids such as dexamethasone [292,293] or budesonide/formoterol [294,295]. Moreover, supplementation with vitamin D [296] in a Phase 2 trial has shown a reduction in markers of vascular permeability from lung injury patients following esophagectomy in the post-operative period [297], although another trial using vitamin D to prevent acute respiratory tract infections has been less conclusive [298]. Other emerging therapies in Phase 2 trials include aspirin, which has attracted interest as a repurposed drug for ARDS [299,300], with some clinical studies [301] that show significant reduction in neutrophil infiltration into the alveolar space. Alternatively, different studies using mesenchymal stem cells (MSCs) and multipotent adult progenitor cells (MAPCs) have shown a biological decline in angiopoietin and a concomitantly reduced 28-day mortality, higher ventilator-free days, and higher ICU-free days [302]. Vitamin C acts as ROS scavenger, modulator of inflammatory mediators, and cofactor. In mouse models, ALI prevents the activation of NF- $\mathrm{kB}$, and therefore attenuates the production of proinflammatory cytokines and boosts ion channel and pump expression, enhancing fluid clearance in the alveolar epithelium [303]. The phase 2 CITRIS-ALI trial is presently investigating the usefulness of vitamin C in sepsis-induced ALI [304] but no positive results have been reported as yet [305]. It was found that nebulized liquid heparin increased the number of 
ventilator-free days [306], and a Phase 2 trial to confirm the findings is awaited [307]. Anti-tissue factor antibodies such as ALT-836, which blocks binding to coagulation factor VIIa, have demonstrated attenuation of sepsis-induced ALI in animal models, and was successfully tested in a Phase 1 trial for ARDS [308]. A Phase 2 trial has been recently completed and disclosure of the results is pending [309]. Dilmapimod, a p38 MAPK inhibitor, has proven useful for reducing the severity of ALI in animal studies, although in human trials it has been unreliable [310,311]. Neutrophil elastase inhibitors such as sivelestat, have been shown to increase the ventilator-free days in ARDS patients with a high extravascular lung water content $(>10 \mathrm{~mL} / \mathrm{kg})$ as compared with those with low pulmonary edema [312], although contradictory results have also been obtained [313,314]. Ulinastatin (or urinary trypsin inhibitor) is another physiological inhibitor of human neutrophil elastase with positive results in preclinical studies [315]. A meta-analysis of 29 Chinese randomized controlled trials (RCTs) indicated that ulinastatin was effective ameliorating ARDS [316]. Another multi-center Phase 2 RCT is ongoing to assess its safety and efficacy in ARDS [317]. Regarding granulocyte-macrophage colony stimulating factor (GM-CSF), preclinical models have demonstrated that it can limit alveolar epithelial cell injury and promote alveolar macrophage maturation. Nevertheless, a Phase 2 RCT enrolled only two-thirds of its intended number of participants and, although GM-CSF treatment appeared to be safe, it did not decrease ventilator free days or mortality of the ALI/ARDS patients [318]. Anti-CD14 antibodies protected against septic hypotension in animal models of pneumonia [319]. Two Phase 2 trials have been initiated in this regard, the former, in 2007, failed in recruiting people; and the latter is still recruiting [320]. Inhaled prostaglandins, such as epoprostenol and alprostadil, have been suggested to regionally dilate the pulmonary vasculature increasing arterial oxygenation in ARDS. However, a meta-analysis of 25 studies concluded that, although indeed inhaled prostaglandins improved oxygenation in ARDS, they did not improve pulmonary physiology or mortality [321].

\section{Preclinical Studies}

The focus of preclinical studies has been basically on antioxidants, antiproteases, and signal transduction inhibitors. Histones have strong proinflammatory, cell damaging, and procoagulant activities in the airways. Targeting histones in the lung with neutralizing monoclonal antibodies $(\mathrm{mAb})$ provides high-level protection against the development of ALI [322]. An alternative strategy for ALI-induced sepsis employed a non-anticoagulant heparin derivative that binds to histones and prevents histone-mediated cytotoxicity, mitigating mortality in sepsis mouse models [323]. Because of the variety of chemokines and cytokines, and the overlapping interactions with their receptors, in vivo blockade of these mediators with mAbs would likely not be effective in ALI patients. Nonetheless, the IL-1 $\beta$ receptor antagonist (anakinra), which neutralizes inflammasome-derived IL- $1 \beta$ and has proven effective in rheumatoid arthritis [324] and in complement-dependent collagen-induced arthritis in mice [325], might also improve ARDS outcomes. Among the antioxidants, there are several natural products such as curcumin, ginsenoside, alpinetine, and honokiol [326].

\subsection{Asthma}

Over the last few years, multiple biologics (typically mAbs) have been developed targeting various participants in allergies and asthma, but mainly directed toward the complex type 2 endotype [327,328]. In general, they are anti-inflammatory treatments [329]. The most prevalent biologics are omalizumab (anti-IgE) and mepolizumab (anti-IL-5). IL-5 has become a major target for both asthma and COPD due to the high proportion of patients with airway eosinophilia associated with disease severity [330]. Currently, three biologics, targeting IL-5 or its receptor, have been cleared by the Food and Drug Administration (FDA). Omalizumab was initially approved by the FDA in 2003 and binds to both the high-affinity and low-affinity IgE receptors, preventing free IgE from occupying the surface of mast cells and basophils [331]. It has several disadvantages, i.e., it must be administered by subcutaneous injection [332], it is expensive [333] and, moreover, an unusual form of anaphylaxis [334] and a possible higher rate of cardiac and cerebrovascular events can 
be ensued by this treatment. Anti-IL-5 (mepolizumab) was approved in late 2014 and receiving patients had decreased eosinophilic inflammation, reduced asthma exacerbations, improved asthma control markers, better quality of life $[335,336]$, and reduced levels of some of the proteins that drive airway remodeling [337]. In another study on moderate persistent asthma, despite high-dose ICS, patients also showed decreased blood and sputum eosinophils but no change in FEV1, symptom scores, or need for rescue inhaler. After stopping anti-IL-5 treatment, eosinophils and asthma symptoms again increased [338]. Reslizumab, another mAb targeting IL- 5, approved in 2016 for patients with eosinophilic asthma, has proven beneficial on moderate-to-severe asthma symptoms, improving lung function and reducing exacerbations as compared with a placebo [339]. Reslizumab also decreased blood, sputum, and airway eosinophils and, more recently, reduced systemic corticosteroid dosing nearly 75\% [340-342]. Benralizumab, a mAb targeting the IL-5R $\alpha$, was approved recently by the FDA [343] with positive results in asthma [344-346]. Finally, dupilumab, a mAb approved in 2017 that inhibits the IL- 4R subunit [347], has also shown encouraging results in asthma [348,349]. Regarding relevant future targets pending approval, lebrikizumab and tralokinumab, mAbs that target IL-13 [350,351], have not shown positive effects [352,353]. Tezepelumab (AMG157), a humanized mAb currently in Phase 3 [354] binds thymic stromal lymphopoietin, an epithelial cell-derived cytokine that drives allergic inflammatory responses [355]. Additionally, anti-IL-33 therapies are currently under development [356]. Conversely, non-Th2 inflammation targets are also being studied. IL-6 and IL-17 may promote both Th2 and non-Th2 inflammatory cascades. Brodalumab is a human mAb binding IL-17RA, which inhibits signaling of IL-17 and IL-25, with disappointing results in clinical trials [357]. Thus, this therapy has not been further pursued for asthma or COPD. C-X-C motif chemokine receptor 2 (CXCR2) antagonists such as navarixin (which decrease IL-8 levels) have reduced sputum and blood neutrophils, with no significant change in FEV1 [358], but has progressed to a Phase 2 trial [359]. An antisense oligonucleotide against C-C chemokine receptor 3 (CCR3) (co-administered with an antisense oligonucleotide that targets the $c$ subunit of the IL-3, IL-5, and GM-CSF receptors), named TPI ASM8, has shown some efficacy in phase 2 trials [360]. Imatinib is a tyrosine kinases inhibitor that has shown promising results in a clinical study, reducing airway hyper-responsiveness as compared with a placebo [361]. Among drugs targeting TNF- $\alpha$, etanercept stands out as a repositioning drug for asthma. A few studies employing etanercept have reported satisfactory results reducing bronchial hyperreactivity [362,363], whereas other studies have informed poor clinical efficacy in terms of lung function improvement and quality of life [364]. Others have shown a small but significant increase in the quality of life without changes on lung function [365].

Among anti-inflammatory treatments, antioxidant treatments stand out $[98,366]$. Vitamins (E, C, $\mathrm{D}$, and $\mathrm{A})$, carotenoids ( $\alpha$-carotene, $\beta$-carotene, $\beta$-cryptoxanthin, lutein/zeaxanthin, and lycopene), and food supplements (selenium and zinc) seem to improve the prognosis of the disease $[102,367,368]$. Asthmatic adults with antioxidant-poor diets have lower forced expiratory volume in the first one second to the forced vital capacity (FEV1/FVC) ratio scores, increased plasma C-reactive protein, and were more likely to exacerbate than those on an antioxidant-rich diet [369]. Indeed, dietary antioxidant supplementation notably improved both symptoms and lung function in exercise induced asthma [370].

\section{Preclinical Studies}

Thiol-based antioxidants are popular supplements to trigger GSH conversion. N-acetyl cysteine is the most commonly used thiol precursor. Thus, $\mathrm{N}$-acetyl cysteine supplementation remarkably decreased inflammatory cytokines (IL-13, IL-5), neutrophil, and eosinophil numbers in the bronchoalveolar lavage fluid (BALF) from a mouse model [371], which has been associated with excessive bronchoconstriction [372]. Among natural extracts, sakuranetin is a flavonoid that can attenuate airway hyperresponsiveness, while decreasing oxidative stress (8-isoprostane), Th2 proinflammatory cy tokines, IgE, and vascular endothelial growth factor levels in the lungs, similar to dexamethasone. Moreover, it can reverse airway remodeling by controlling NF-kB activation [373,374]. 
Astragalin, another flavonoid, suppresses eosinophil infiltration $[375,376]$. Resveratrol has been shown to decrease p47phox expression and ROS production, increase SOD levels, and reverse elevated TNF- $\alpha$ and inducible NOS (iNOS) from lung tissue [377,378]. Morin, an active ingredient obtained from Moraceae plants, abolished intracellular ROS and MAPK [86] and attenuated the extensive trafficking of inflammatory cells into BALF from ovalbumin (OVA)-challenged mice and rats [379]. Boerhavia procumbens inhibited oxidative stress pathways, reducing the anti-inflammatory response, and improving lung injury [380]. Esculentoside A and Sonchus asper extract significantly upregulated Nrf-2 expression, SOD activity, and intracellular GSH levels [381,382]. Oral treatment with Capsicum annuum L. methanolic extract remarkably decreased the pathophysiological signs of OVA-induced airway inflammation, reducing ROS levels of BALF in asthmatic mice [383]. Carissa opaca fruit extracts can restore the activities of antioxidant enzymes and lipid peroxidation [384,385]. Furthermore, antioxidant synthetics such as Y-27632, a Rho-kinase inhibitor, controls airway inflammation and responsiveness, the remodeling response, and oxidative stress in guinea pigs [386,387]. Treatment with $1400 \mathrm{~W}$ (an iNOS-specific inhibitor), nor-HOHA (an arginase inhibitor), or NaHS (a hydrogen sulfide $\left(\mathrm{H}_{2} \mathrm{~S}\right)$ donor) decreased pro-contractile 8 isoprostane expression and modulated arginase 2 and iNOS pathways, contributing to reduced NF-KB expression in distal lung tissue. These inhibitors also mitigated eosinophil infiltration and increased tissue resistance and elastance [388,389]. HYDAMTIQ is a promising poly (ADP-ribose) polymerase inhibitor that prevents lung inflammation, airway remodeling and damage in asthma [390]. An angiotensin-I converting enzyme 2 (ACE2) activator, diminazene aceturate, attenuates allergic airway inflammation in a rat asthma model [391]. Diallyl sulfide decreases infiltrated inflammatory cell count and Th2 proinflammatory cytokines in BALF from OVA-challenged mice [392]. Mice treated with S-adenosylmethionine, a potent methyl donor, had decreased amounts of Th2 proinflammatory cytokines and 4-hydroxy-2-nonenal in lung tissues [393]. Pituitary adenylate cyclase-activating polypeptide reverses vanadate-induced airway hyperresponsiveness in rats, mainly through bronchodilator activity and counteraction of proinflammatory and pro-oxidative effects [394].

Furthermore, a multiple targeting approach against oxidizing molecules, PRRs and transcription factor modulators could improve outcomes in asthma. Flavonoids have stronger radical scavenging activity as compared with many other natural antioxidants because of multiple hydroxyl groups present in its chemical structure [395-399]. Ambroxol is a mucoactive agent with anti-inflammatory and antioxidant activities used to increase mucociliary clearance and regulate surfactant levels in the upper respiratory airways [400]. The salicylic acid derivative 5-aminosalicylic acid reduces leukocyte count, the expression of Th2 cytokines, and oxidative stress markers in the BALF from asthmatic mice [401]. Sitagliptin and Cinnarizine also reduce proinflammatory cytokine release and inflammatory infiltration, while restoring GSH and SOD, thus, playing a role attenuating airway inflammation and remodeling through antioxidative stress [402,403]. However, some of the above approaches have failed due to unanticipated side effects. Thus, as yet, no antioxidants have been employed as first-line therapy for asthma.

\section{3. $C O P D$}

Thus far, no anti-IL-5 therapies have been approved for use in COPD. However, two Phase 3 studies using mepolizumab showed improvements in exacerbation frequency from subjects who had an eosinophilic phenotype and a history of COPD exacerbations, despite triple therapy [404]. Nevertheless, other studies have indicated no positive effects [405]. Reslizumab has yet to be formally evaluated in clinical trials for COPD. Conversely, in a Phase 2 trial including COPD patients with eosinophilia, benralizumab treatment did not significantly reduce the annual rate of moderate or severe exacerbations $[406,407]$. However, significant improvements in FEV1 were observed in the overall study population, and the results of pre-specified subgroup analyses by baseline blood eosinophil count in individuals with benralizumab versus placebo have led to an ongoing Phase 3 trial to evaluate this biologic in COPD [408]. As in asthma, non-Th2 inflammation targets include CXCR2 and CCR3. Regarding corticosteroids, in contrast to asthma, glucocorticoid treatment of established COPD is 
rather ineffective in reducing chronic airway inflammation and progressive airway obstruction [409]. Current national and international guidelines endorse the use of inhaled long acting bronchodilators, ICSs, and their combination for maintenance treatment of moderate-to-severe stable COPD [410], although adverse effects may arise [411]. In fact, large clinical trials assessing the combination therapy (ICSs + LABAs) in a single inhaler for stable COPD patients have shown a good safety profile, a discreet but statistically significant reduction of severe exacerbations, and improvements of FEV1, quality of life, and respiratory symptoms in these patients [412,413]. Overexpression of histone deacetylase 2 restores glucocorticoid sensitivity in BAL macrophages from COPD patients [414]. Anti-cytokine and anti-chemokine treatments are being exploited in COPD but scarce trials using blocking antibodies against cytokines and chemokines or their receptors have proven successful [409]. Among those showing positive effects, the CXCR2 inhibitor MK-7123 (also known as SCH527123 or navarixin, already described in asthma) could reduce the chemotaxis of neutrophils [409]. MK-7123 treatment resulted in a significant reduction of sputum neutrophils and of sputum and plasma MMP9 and myeloperoxidase levels [415]. Numerous other drugs, including antibodies directed against specific inflammatory mediators such as cytokines (IL-18, IL-22, IL-23, IL-33, TSLP) and growth factors (GM-CSF) are under investigation for COPD.

\section{Preclinical Studies}

The treatment of respiratory symptoms is the focus of most therapies for COPD, since therapies for comorbidities are ineffective or inexistent. Thus, there is a need for the identification of the mechanisms which relate COPD to its comorbidities, and preclinical models have been developed to solve this [416]. Pharmacological activation of soluble guanylate cyclase, involved in the nitric oxide-cyclic guanosine $3^{\prime}, 5^{\prime}$-monophosphate (NO-cGMP) signaling pathway, has been shown to prevent the development of emphysema and pulmonary vascular remodeling in animal models of COPD [417]. Regarding the cardiovascular effects of COPD, N-acetyl cysteine or the proteasome inhibitor bortezomib attenuated muscle mass loss and wasting [418]. The inflammation is also very important and airway epithelial cells, oxidative damage, epithelial-mesenchymal transition, and airway remodeling have also been considered to be potential therapeutic targets [419]. The mesenchyme plays a key role in COPD, and bromodomain-containing protein (BRD) along with NF- $\mathrm{KB}$, contribute to mesenchymal transition. Selective inhibitors of the epigenetic regulator BRD4, specifically targeting TLR3-induced airway inflammation, have been developed through structure-based drug design [420,421]. The aim is to decrease the levels of neutrophilic inflammation in the airways and prevent the alteration of the epithelial cell state, reducing myofibroblast growth in infection exposures. MSCs may also be used as a therapeutic strategy for the treatment of COPD, reducing inflammation, antimicrobial actions, and promoting lung epithelial and endothelial repair [422].

\subsection{Idiopathic Pulmonary Fibrosis (IPF)}

After several disappointing years of promising therapies that moved into clinical trials but failed to demonstrate efficacy in IPF [423], the anti-fibrotic drugs pirfenidone and nintedanib have been associated with significantly slower respiratory deterioration and perhaps prolonged survival $[236,237,424]$, although with heterogenous responses and side effects. The understanding of the complex pathogenesis of IPF continues to increase [425,426]. Sustained alveolar epithelial cell injury and abnormal repair are increasingly recognized as the core mediators of the fibrotic process, with a relevant involvement of environmental triggers. The activation of multiple pathways related to maladaptive repair, involving fibroblast migration, proliferation, and extracellular matrix deposition has revealed a variety of prospective molecular targets of novel therapeutic agents currently being tested in early phase clinical trials. Pentraxin-2 (PTX-2) is a circulating protein that binds to monocytes, promoting epithelial healing and resolution of fibrosis. Thus, a recombinant human PTX-2 (serum amyloid P) analogue (PRM-151) has been shown to inhibit monocyte to fibrocyte differentiation and ameliorate fibrosis in a bleomycin-induced animal model of fibrosis [427,428]. A Phase 1 trial 
showed a non-significant but improving effect of PRM-151 on FVC and six-min walking distance (6MWD) during the treatment [429]. Further Phase 2 studies have demonstrated a significant reduction in pulmonary function deterioration and stability in 6MWD over 24 weeks as compared with a placebo, although with relevant adverse events [430,431]. The launch of a Phase 3 trial for PRM-151 in IPF has been announced, using FVC as a primary end point and 6MWD as a key secondary end point. Among the anti-connective tissue growth factor antibodies, the antagonist pamrevlumab (FG-3019) in the PRAISE study [432] was established to have a significant effect preventing lung function decline of 160 IPF patients, yet full peer-reviewed data are still awaited [433]. The re-initiation of Phase 3 trials has just been announced. PBI-4050 is a synthetic analogue of a medium-chain fatty acid acting through $G$ protein-coupled receptors and showing anti-fibrotic activities such as inhibition of epithelial-mesenchymal transition and fibrocyte/fibroblast recruitment, migration, proliferation and differentiation, among others [434]. A Phase 2 trial has shown no safety concerns [435]. While there was slowing or stability in FVC, a statistically significant decrease was observed only combining PBI-4050 and pirfenidone but not PBI-4050 and nintedanib, implying a possible drug-drug interaction. Additional studies of PBI-4050, either alone or in combination with nintedanib, are currently being considered. In a Phase 2a study [436], GLPG1690, an oral selective inhibitor of autotaxin (an enzyme increased in IPF and involved in cell apoptosis and endothelial cell damage) was analyzed and was well tolerated by IPF patients, with a good safety profile. Moreover, as secondary end points, preliminary efficacy analyses demonstrated target engagement and encouraging results towards halting FVC decline [437]. International Phase 3 trials to assess the efficacy of GLPG1690 in IPF are ongoing [438]. Leukotrienes are also increased in IPF $[439,440]$. Thus, additional ongoing trials include leukotriene antagonists such as tipelukast, currently explored in a Phase 2 trial [441]. Among protein kinase inhibitors, a recent Phase 1 study showed proper safety and tolerability of a selective protein kinase inhibitor of the Rho-associated coiled-coil containing protein kinase 2 (ROCK2). The trial is currently in Phase 2 [442,443]. Moreover, a current Phase 2 [444] trial is evaluating CC-90001, a second-generation Jun N-terminal kinase (JNK) inhibitor after a first-generation JNK inhibitor (CC-930) showed a dose-dependent trend of reduction in MMP7 and surfactant protein D (SP-D) biomarker plasma levels [445]. Regarding anti-integrin antibodies, a partial inhibition of integrin $\alpha \mathrm{v} \beta 6$ in rodents blocked the development of pulmonary fibrosis processes without aggravating the inflammatory response [446]. The safety and tolerability of a humanized monoclonal antibody (BG00011) against this integrin has been analyzed in a Phase 2 trial [447]. The study has been completed recently, although its outcome is still pending. Phosphatidylinositol 3-kinase/Protein kinase B (PI3K/Akt) pathway inhibitors may be associated with halting fibrosing processes [448], as suggested in a Phase 1 trial $[449,450]$ and evidenced in another recent study using omipalisib [451]. Sirolimus is currently under examination in a Phase 2 trial [452]. The B lymphocyte antigen CD20 is targeted by rituximab, which is currently being assessed in an IPF Phase 2 study [453]. Furthermore, a Phase 2 trial examined combined plasma exchange, rituximab, and steroids [454]. While peer-reviewed results are pending, a pilot trial stated good outcomes regarding autoantibody reduction for acute IPF exacerbations [455]. A Phase 3 trial testing the antibiotic combination co-trimoxazole (trimethoprim and sulfamethoxazole) is currently operating [456]. Finally, other anti-inflammatory drugs are likewise in clinical research for IPF, i.e., lebrikizumab [457], tralokinumab [458], and azithromycin [459].

\section{Preclinical Studies}

Administration of the senolytic drug quercetin attenuates the proinflammatory phenotype of bleomycin-induced senescence in fibroblasts [460]. Moreover, the anti-fibrotic activity of quercetin was superior to that of vitamin $\mathrm{E}$ in bleomycin-induced pulmonary fibrosis in rats [461]. When given in combination, the tyrosine kinase inhibitor dasatinib and quercetin depleted senescent cells and improved lung function and fibrotic markers following bleomycin injury [462-465]. Different preclinical and clinical trials testing the senolytic cocktail dasatinib plus quercetin has shown both positive outcomes [466] and negative ones $[467,468]$. Other senolytics with positive preclinical studies are 
curcumin, fisetin and fisetin-loaded mesoporous carbon nanoparticles [469], and navitoclax [470]. Therefore, the promising expectations generated in preclinical studies supports proof-of-principle clinical trials with senolytic agents for IPF treatment [471]. Conversely, it has also been suggested that senolytic drugs could be detrimental to IPF patients [460].

\subsection{Cystic Fibrosis (CF)}

To address the most prevalent causal defects in the CFTR $\mathrm{Cl}-$ channel leading to $\mathrm{CF}$, two biomolecular modulators are needed, i.e., CFTR correctors, to increase the amount of properly folded mutant CFTR protein at the plasma membrane, and CFTR potentiators, to allow effective gating (channel opening and closing) of the abnormal CFTR [472-474]. Nevertheless, a more thorough division might also include stabilizers, read-through agents, and amplifiers [475]. Either alone or combined, these modulators tend to restore transepithelial $\mathrm{Cl}^{-}$transport to $\mathrm{CF}$ airway epithelia expressing CFTR mutations such as the most prevalent F508del, improving hydration and restoring mucociliary clearance [476,477]. Four drugs have been recently approved by the FDA for that purpose [474], the potentiator Ivacaftor (VX-770) for individuals with CF holding a G551D CFTR mutation, and the following three correctors: Lumacaftor (VX-809), developed to increase the amount of F508del CFTR that reaches the cell surface [478,479], Tezacaftor (VX-661), and Elexacaftor (VX-445). Furthermore, their combinations are also being assayed, i.e., Orkambi (lumacaftor/ivacaftor) for patients homozygous for F508del CFTR [480], Symdeko (tezacaftor/ivacaftor), and Trikafta (elexacaftor/tezacaftor/ivacaftor). Most recently, there has been an explosion of novel modulators [481] and others are under investigation including ELX-02, Posenacaftor (PTI-801), Galicaftor (ABBV-2222), ABBV-3221, FDL169, Deutivacaftor (VX-561), ABBC-974 (GLPG-1837), and Nesolicaftor (PTI-428) [482-491], among others.

Despite a thorough knowledge of the undergoing inflammatory process in $\mathrm{CF}$, there are relatively few anti-inflammatory drugs in clinical use [492]. Corticosteroids were shown to confer some benefit but their long-term use is associated with unacceptable side effects [493-495]. The non-steroidal anti-inflammatory agent ibuprofen has also demonstrated benefits $[279,280]$. Particularly in younger patients, it has been associated with an increased survival rate [496,497], but it requires a strict dose control and has associated renal and gastrointestinal side effects [279]. A large Phase 2 RCT of the leukotriene B4 (LTB4) receptor antagonist, BIIL 284 BS (amelubant), surprisingly demonstrated an excess of pulmonary exacerbations as compared with a placebo [498]. Conversely, CTX-4430 decreases the production of LTB4, an inflammatory mediator elevated in CF [499] and is presently undergoing a Phase 2 trial [500]. Andecaliximab, an antibody against MMP9, is undergoing a Phase $2 \mathrm{~b}$ trial [501] but the baseline FEV1 required for this drug limits its use in very severe CF and this trial has been discontinued. Another compound in Phase 1 is POL6014, a synthetic neutrophil elastase blocker [502]. Other anti-inflammatory compounds under clinical development are $\alpha-1$ anti-trypsin [503], the elastase inhibitor AZD9668 [504], and JBT-101 (ajulemic acid, or Lenabasum), an oral selective cannabinoid receptor type 2 (CB2) agonist that decreases neutrophilic inflammation inhibiting LTB4 and promotes resolution of inflammation through modulation of arachidonic acid metabolism [505]. A Phase 2, double-blind, placebo-controlled study, in adult CF patients, demonstrated decreased levels of several sputum inflammatory markers and reduced exacerbations in response to JBT-101, with no serious adverse effects reported [506,507]. A Phase $2 b$ study is underway. Indeed, CB2 activation has shown anti-inflammatory effects including stimulating lipoxin A4 (LXA4) synthesis, decreasing proinflammatory cytokine secretion, and neutrophil trafficking to the lung [508,509].

Anti-proteases have been under investigation in CF since 1990. For example, the already described $\alpha 1$-antitrypsin suppressed inflammatory markers including free neutrophil elastase, proinflammatory cytokines, and neutrophils [510,511]. Other neutrophil elastase inhibitors include recombinant secretory leukocyte protease inhibitor (rSLPI) and the small-molecule drug EPI-hNE4 (depelstat) [512]. Among other inflammatory therapies, hydroxychloroquine, a dihydrofolate reductase inhibitor that increases intracellular $\mathrm{pH}$, was negatively evaluated in a small 28-day study in CF [513]. A CF clinical trial regarding SB-656933, a CXCR2 antagonist, concluded that this molecule might modulate 
airway inflammation [514]. Conversely to refractory asthma, few CF studies have considered the use of chemotherapeutics. Low dose of the immunosuppressant cyclosporin A diminished the need for systemic corticosteroids in one small case series. In a pilot study, methotrexate increased FEV1 and decreased total serum immunoglobulins in five CF patients after one year of treatment [515], showing tolerable adverse effects. IL-8 decoys are used as an anti-inflammatory anti-neutrophil elastase strategy [516,517]. Other novel anti-inflammatory compounds under review include the already mentioned lipoxins and resolvins. Arachidonic acid-derived lipoxins such as LXA4 attenuate neutrophil chemotaxis, respiratory burst, IL-8 production, and accelerate apoptosis [518-520]. Because of low LXA4 levels in CF airways, stable LXA4 agonists have been developed as prospective therapeutics. Decosahexanoic acid- and omega-3 eicosapentanoic acid-derived resolvins D1 and E1 also mitigate inflammation, preventing chemotaxis and promoting clearance of apoptotic neutrophils [521-524]. Analogously to LXA4, resolvins stimulate a cytoprotective effect on airway epithelial cells $[525,526]$. Retinoids foster extracellular matrix homeostasis. Recent Phase $1 \mathrm{~b}$ studies involving LAU-7b, an oral solid-dosage form of the retinoid fenretinide, showed safety and tolerability in adult CF patients, encouraging progression to Phase 2 trials [527].

Antioxidant therapies have not been yet settled in clinical practice [528]. In fact, despite the commercial development of many natural antioxidants as dietary supplements, there is no sound clinical trial evidence of their effectiveness in any clinical condition [529] with the exception of GSH (administered either orally or by inhalation) [530-532] with some drawbacks [533]. Though not quite clear [534], high doses of $\beta$-carotene appear to improve lung function and decrease oxidative stress in some cases [535]. The application of deferiprone (L1) as an iron chelating drug/pharmaceutical antioxidant is under way. Its use is being considered as a main, alternative, or adjuvant therapy in many diseases involving oxidative damage [536,537]. N-acetyl cysteine, initially developed as a mucolytic, is being repurposed as an antioxidant [538], inhibiting $\mathrm{H}_{2} \mathrm{O}_{2}$ and increasing GSH [531]. Of significance is the malabsorption of fat-soluble antioxidants in CF patients such as tocopherols, carotenoids, and coenzyme Q10 (Co-Q10), and that of essential fatty acids. Vitamin E might become a good supplementation to overcome this deficiency [539-543], along with carotenoids [544] and ascorbic acid (vitamin C) as nutritional supplements. Multivitamin supplements with high bioavailability containing Co-Q10 would also be a good alternative $[545,546]$. One recent study regarding multivitamin supplements showed a decrease in circulating inflammatory markers and a decrease in pulmonary exacerbations [547]. Alternatively, several hydro soluble antioxidants, oligoelements, and enzymatic antioxidants such as Vitamin C, selenium and selenium-dependent peroxidases [548-550], zinc, and copper [551] have yielded promising results awaiting further clinical trials. A randomized double-blind placebo-controlled trial has examined the outcome of short-term melatonin administration ( $3 \mathrm{mg}$ for three weeks) on sleep and oxidative stress markers in CF [552]. Accordingly, with the expected activity synchronizing the sleep-wake cycle and its antioxidant properties, treatment with this hormonal substance reduced nitrite levels in exhaled breath condensate and improved sleep indices.

\section{Preclinical Studies}

Anti-inflammatory cytokines and antibodies to proinflammatory cytokines may show efficacy in CF. IL-10 possesses anti-inflammatory properties. Interferon- $\gamma 1 \mathrm{~b}$, another cytokine with immunomodulatory activities, did not improve pulmonary function nor alter bacterial burden or inflammatory markers in the sputum in a multicenter clinical trial, despite its ability to restore macrophage activation and antimicrobial, antiproliferative, and anti-fibrotic functions in CF cell models [553]. To inhibit specific proinflammatory mediators, antibodies to intercellular adhesion molecule 1 (ICAM-1) and IL-8 have been evaluated in preclinical studies [554], although they never progressed to clinical trials. Anti-IL-17 antibodies reduced airway neutrophilia in mice exposed to LPS [555]. Because of the similarities between CF airway inflammation and hyperinflammatory conditions such as rheumatoid arthritis or psoriasis, for which clinical trials using anti-IL-17 antibodies have been completed, targeting IL-17 could also be of therapeutic value for CF treatment. 
Among intracellular signaling modulators, ibuprofen (previously described), and IL-10 inhibit NF- $\mathrm{KB}$ activation. NF- $\mathrm{KB}$ activity inhibition also occurs through upregulation of peroxisome proliferator activating receptor (PPAR- $\gamma$ ) using PPAR- $\gamma$ agonists such as thiazolidinediones (glitazones) [556-558]. Troglitazone and ciglitazone activate PPAR- $\gamma$ in primary CF airway epithelial cells and reduce the production of proinflammatory mediators in response to P. aeruginosa [559]. Statins have anti-inflammatory effects, including the ability to inhibit neutrophil migration, decrease proinflammatory cytokine production, and increase transcriptional activation of PPAR [560-562].

Agents that augment endogenous NO production, exhibiting anti-inflammatory activity, have also been examined. In a rodent model of chronic airway infection, L-arginine, which increases NO production, was associated with reduced tissue damage, decreased neutrophil recruitment, and reduced IL-1 $\beta$ [563]. Synthetic triterpenoids are small-molecule derivatives of naturally occurring compounds holding cytoprotective functions that increase antioxidant Nrf2 activity, and therefore could also be considered for clinical trials.

In addition, consumption of long chain fatty acids (omega- 3 supplements) seems not to have a clear anti-inflammatory effect and, consequently, a positive benefit on CF disease severity [564].

Among emerging antioxidant and anti-inflammatory approaches for $\mathrm{CF}$, targeting NF- $\mathrm{kB}$ with natural compounds such as resveratrol and plant extracts is highlighted. Resveratrol $\left(3,5,4^{\prime}\right.$ trihydroxystilbene, "E" form) is one of the most investigated natural antioxidants with a purported activity as NF- $\mathrm{KB}$ inhibitor. The antioxidant activity of resveratrol has been reported in several studies and also occurs in lung tissues, suggesting that resveratrol has potential as a therapeutic agent in respiratory diseases $[260,565,566]$. The drug Meveol ${ }^{\circledR}$ is a complex of lactoferrin and the anion hypothiocyanite $\left(\mathrm{OSCN}^{-}\right)$, with a proposed in vivo antimicrobial activity [567] to be evaluated in clinical trials as aerosol treatment for lung infections in CF patients. A role for this drug in the control of $\mathrm{H}_{2} \mathrm{O}_{2}$ levels in the airway surface liquid remains to be investigated. In addition, preclinical studies [568] have shown novel anti-inflammatory effects and antimicrobial potential of the anion thiocyanate $\left(\mathrm{SCN}^{-}\right)$ in lung infection, which decreases BALF chemokine keratinocyte chemoattractant (KC) (analog to human IL-8), IL-1 $\beta$, TNF- $\alpha$, and airway neutrophil infiltrate concurrent with the infectious stimulus, and enhances bacterial clearance in both wild-type and transgenic mice overexpressing the $\beta$ subunit of the epithelial sodium channel Scnn1 ( $\beta E N a C)$. Therapeutic potential of selenium-derived compounds may derive from their significant activity as inducers of phase II enzymes such as quinone reductase and GSH-S-transferase [569], increasing the capacity to metabolize/detoxify endobiotics generated during oxidative stress and inflammation [570].

\section{Concluding Remarks}

Because inhaled oxygen along with environmental pollutants, pathogens, and allergens, which have intrinsic oxidative potential, dissolve in the respiratory epithelial lining fluid, oxidative stress and inflammation take center stage in the wide spectrum of respiratory pathologies, a major source of disability and death following cardiovascular diseases. Thus, a timely diagnosis, treatment, as well as the management of pulmonary diseases is important. In that sense, preventive measures such as enhancement of antioxidant defenses or corrective actions to mitigate abnormal immune-inflammatory responses, whether efficacious, could provide more options for patients and clinicians. Nevertheless, the last two decades have witnessed no major breakthroughs regarding medications for most of the respiratory diseases (Table 1). On the one hand, traditional adjuvant therapies such as mechanical lung ventilation for ALI/ARDS or chest physiotherapy and antibiotic therapy in CF improve patient survival slightly. On the other hand, the use of corticosteroids has become commonplace as anti-inflammatory treatment, although with limited efficacy and relevant side effects. Thus, novel drugs or drug combinations targeting relevant players in the disease process, such as neutrophil elastase inhibitors for ALI/ARDS and CF, antibodies against cytokines, chemokines or its receptors for asthma, COPD and CF, anti-fibrotic drugs for IPF, and, ultimately, the recently approved CF therapies targeting CFTR mutations 
(Figure 2) might represent a step forward to increase specificity and reduce adverse events. Moreover, new cutting-edge technologies, including single-cell next-generation sequencing, genome-wide in silico or phenotypic screenings to identify novel drug targets, and stem cell therapeutics should yield more efficacious and safe drugs to approach personalized treatments for a variety of airway dysfunctions. In fact, by gaining a better understanding of lung pathophysiology at the molecular level using new emerging technologies, the achievement of better outcomes in patients with respiratory pathologies will become a reality.
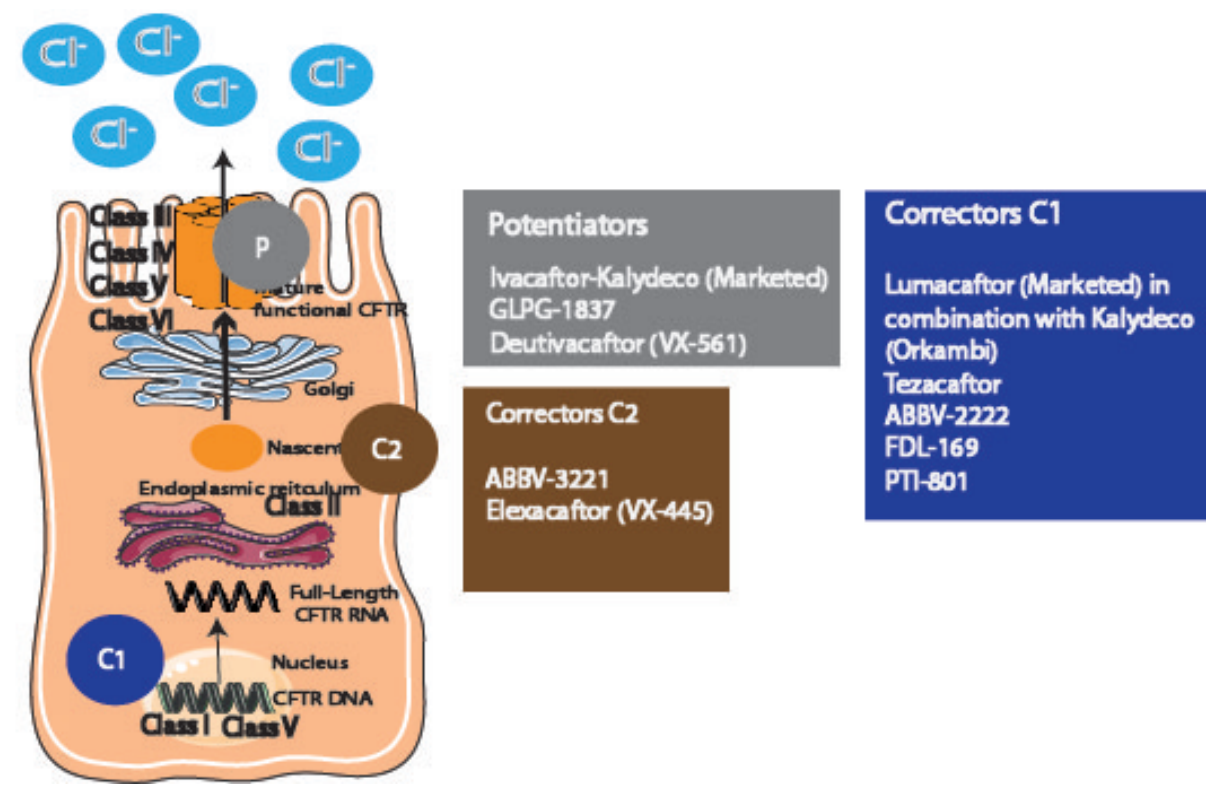

Figure 2. Different CFTR modulators and their targets. Abnormal CFTR protein biosynthesis/function according to the following different classes of CFTR gene mutations: Class I mutants involve no protein synthesis. Premature stop codons, frameshifts, or deletions preclude translation of full-length CFTR; Class II mutants, among them the most common mutation, F508del, have impaired trafficking due to incorrect folding; Class III mutants have defective channel gating; Class IV mutants hold reduced function, such as reduced chloride $\left(\mathrm{Cl}^{-}\right)$conductance; Class V mutants allow a reduced CFTR cannel number or maturation as a result of amino acid substitution or alternative splicing; and Class VI mutants support a less stable protein, since the recycling CFTR channel is sent for lysosome degradation. These phenotypes can be corrected by rationally designed drugs or drug combinations termed correctors (C1, targeted to class I and class V mutations and C2, targeted to class II mutations), and potentiators (P, targeted to class III-VI mutations). 
Table 1. Most relevant drugs according to respiratory disease type.

\begin{tabular}{|c|c|c|c|c|c|}
\hline Disease & Drug & Target & Biologic Function & Trial & Reference \\
\hline ALI/ARDS & $\begin{array}{l}\text { Corticosteroids } \\
\text { (dexamethasone, } \\
\text { budesonide and } \\
\text { formoterol) }\end{array}$ & Corticosteroid receptors & $\begin{array}{l}\text { Reduce the signs and symptoms of } \\
\text { inflammatory conditions }\end{array}$ & Phase 3 & [292-295] \\
\hline ALI/ARDS & Aspirin & Cox-1 and Cox-2 & $\begin{array}{l}\text { Significant reduction in neutrophil infiltration into the } \\
\text { alveolar space }\end{array}$ & Phase 2 & [299-301] \\
\hline ALI/ARDS & MSCs and MPAs & - & $\begin{array}{l}\text { Reduction in angiopoietin decreased 28-day mortality, } \\
\text { higher ventilator-free days and higher ICU-free days }\end{array}$ & Phase 2 & [302] \\
\hline ALI/ARDS & ALT-836 & Tissue factor (TF) or TF-factor VIIa & $\begin{array}{c}\text { Blocks binding to coagulation factor VIIa and attenuation } \\
\text { of sepsis-induced ALI }\end{array}$ & Phase 2 & {$[308,309]$} \\
\hline ALI/ARDS & Dilmapimod & p38 MAPK Inhibitor & Reduces severity of ALI & Phase 2 & {$[310,311]$} \\
\hline ALI/ARDS & Ulinastin & $\begin{array}{l}\text { Physiological human inhibitor of } \\
\text { neutrophil elastase }\end{array}$ & Effective in ameliorating ARDS & Phase 2 & [315-317] \\
\hline ALI/ARDS & Anti-CD14 antibodies & Amti-CD-14 & Antibodies which protect against septic hypotension & Phase 2 & {$[319,320]$} \\
\hline Asthma and COPD & Omalizumab & Anti-IgE & $\begin{array}{l}\text { Binds to free human IgE, forming small-size immune } \\
\text { complexes, blocking its interaction with the high-affinity } \\
\text { IgE receptor and preventing its contact with mast cells } \\
\text { and basophils }\end{array}$ & Approved & [331-334] \\
\hline Asthma and COPD & Mepolizumab & Anti-IL-5 & $\begin{array}{l}\text { Decreases eosinophils in blood and sputum; fewer asthma } \\
\text { exacerbations, better asthma control, improved quality of } \\
\text { life, and reduced proteins involved in airway remodeling }\end{array}$ & $\begin{array}{l}\text { Approved for } \\
\text { asthma; Phase } 2 \\
\text { for COPD }\end{array}$ & $\begin{array}{l}\text { Asthma: } \\
{[335-338] / \text { COPD }} \\
{[404,405]}\end{array}$ \\
\hline Asthma and COPD & Reslizumab & Anti-IL-5R & $\begin{array}{l}\text { Decreases blood, sputum, and airway eosinophils, reduces } \\
\text { asthma exacerbations, improves lung function, and } \\
\text { reduces systemic corticosteroid dosing by as much as } 75 \%\end{array}$ & Approved & {$[339,340]$} \\
\hline Asthma and COPD & Benralizumab & Anti-IL-5 & Positive results in asthma. Decrease airway eosinophilia & Approved & $\begin{array}{c}\text { Asthma: } \\
{[343-346] / \text { COPD }} \\
{[406-408]}\end{array}$ \\
\hline Asthma & Depilumab & Anti-IL-4R & Positive results in asthma. Decrease airway eosinophilia & Approved & [347-349] \\
\hline Asthma and COPD & Tezepelumab & Humanized monoclonal antibody & $\begin{array}{l}\text { Binds thymic stromal lymphopoietin, an } \\
\text { epithelial-cell-derived cytokine that drives allergic } \\
\text { inflammatory responses }\end{array}$ & Phase 3 & {$[354,355]$} \\
\hline Asthma and COPD & Navarixin & CXCR2 antagonist & $\begin{array}{l}\text { Reduces sputum and blood neutrophils; no significant } \\
\text { change in FEV1 }\end{array}$ & Phase 2 & $\begin{array}{c}\text { Asthma: } \\
{[358,359] / \text { COPD: }} \\
{[409]}\end{array}$ \\
\hline
\end{tabular}


Table 1. Cont.

\begin{tabular}{|c|c|c|c|c|c|}
\hline Disease & Drug & Target & Biologic Function & Trial & Reference \\
\hline Asthma & Etanercept & TNF- $\alpha$ & $\begin{array}{c}\text { Reduces bronchial hyperreactivity; small but significant } \\
\text { increase in quality of life }\end{array}$ & Clinical & [362-365] \\
\hline COPD & ICS + LABA & $\begin{array}{l}\text { Corticosteroid receptors }+ \\
\beta \text {-adrenergic receptors }\end{array}$ & $\begin{array}{l}\text { Significant reduction in the number of severe } \\
\text { exacerbations and improvement in FEV1, quality of life, } \\
\text { and respiratory symptoms in stable COPD patients }\end{array}$ & Approved & {$[412,413]$} \\
\hline IPF & $\begin{array}{l}\text { Pirfenidone and } \\
\text { nintedanib }\end{array}$ & TGF- $\beta$ and angiokinase & $\begin{array}{l}\text { Significant reduction of respiratory deterioration in IPF } \\
\text { and, perhaps, prolonged survival }\end{array}$ & Phase 3 & {$[236,237,424]$} \\
\hline IPF & PRM-151 & $\begin{array}{l}\text { Protein that binds to monocytes } \\
\text { promoting epithelial healing and } \\
\text { resolution of fibrosis }\end{array}$ & $\begin{array}{l}\text { Ameliorates fibrosis in a bleomycin- and } \\
\text { TGF- } \beta \text {-overexpressing animal model of fibrosis }\end{array}$ & $\begin{array}{l}\text { Phase 2, heading } \\
\text { for phase } 3\end{array}$ & {$[427,429-431]$} \\
\hline IPF & Pamrevlumab & CTGF & Reduction of lung function decline & $\begin{array}{l}\text { Phase 2, heading } \\
\text { for Phase } 3\end{array}$ & [433] \\
\hline IPF & PBI4050 & $\begin{array}{l}\text { Analogue of a medium-chain fatty } \\
\text { acid. Activates the GPR40 receptor, } \\
\text { while it suppresses GPR } 84 \text { activity, }\end{array}$ & $\begin{array}{c}\text { Inhibition of endoplasmic reticulum stress and ROS } \\
\text { production, epithelial-mesenchymal transition and } \\
\text { fibrocyte/fibroblast recruitment, migration, proliferation, } \\
\text { and differentiation }\end{array}$ & Phase 2 & {$[434,435]$} \\
\hline IPF & GLPG1690 & Autotaxin & $\begin{array}{l}\text { Selective autotaxin inhibitor. Enzyme increased in IPF and } \\
\text { involved in cell apoptosis and endothelial cell damage, } \\
\text { and LPA inhibitor }\end{array}$ & Phase 3 & {$[436-438]$} \\
\hline IPF & Tipelukast & Leukotriene antagonists & $\begin{array}{l}\text { Downregulation of genes that promote fibrosis, such as } \\
\text { LOXL2, collagen type 1, and TIMP-1; and genes } \\
\text { responsible for promoting inflammation like CCR2 } \\
\text { and MCP-1. }\end{array}$ & Phase 2 & [441] \\
\hline IPF & KD025 & Selective ROCK2 inhibitor & $\begin{array}{l}\text { Downregulates the ability of T cells to secrete IL-21 and } \\
\text { IL-17 in response to T-cell receptor stimulation in vitro; } \\
\text { restores disrupted immune homeostasis }\end{array}$ & Phase 2 & {$[442,443]$} \\
\hline IPF & CC-90001 & Second-generation JNK inhibitor & $\begin{array}{l}\text { Reduces the development of fibrosis, as evidenced by a } \\
48 \% \text { reduction in collagen and a } 53 \% \text { reduction in } \\
\alpha \text {-smooth muscle actin }\end{array}$ & Phase 2 & [444] \\
\hline IPF & BG00011 & $\begin{array}{l}\text { Humanized monoclonal antibody } \\
\text { targeting the alpha-v beta- } 6(\alpha \mathrm{v} \beta 6) \\
\text { integrin receptor }\end{array}$ & $\begin{array}{l}\text { TGF- } \beta \text { suppression as evidenced by reduction in pSMAD2 } \\
\text { signaling and TGF- } \beta \text { dependent gene expression in } \\
\text { bronchoalveolar lavage (BAL) cells; preclinical models } \\
\text { have shown maximal fibrosis inhibition correlating with } \\
70 \% \text { pSMAD reduction. }\end{array}$ & Phase 2 & [447] \\
\hline IPF & Omipalisib & PI3K/Akt pathway inhibitor & Halts fibrosing processes & Phase 1 & [451] \\
\hline IPF & Sirolimus & mTOR & Reduces the number of circulating fibrocytes & Phase 2 & [452] \\
\hline
\end{tabular}


Table 1. Cont.

\begin{tabular}{|c|c|c|c|c|c|}
\hline Disease & Drug & Target & Biologic Function & Trial & Reference \\
\hline IPF & Rituximab & $\begin{array}{l}\text { CD20 surface molecule of B } \\
\text { lymphocytes }\end{array}$ & $\begin{array}{c}\text { Reduction of autoantibodies, a favorable safety profile and, } \\
\text { possibly, stabilization of lung function. }\end{array}$ & Phase 2 & [453-455] \\
\hline IPF & Cotrimoxazole & Antibiotic & Antibacterial drug & Phase 3 & [456] \\
\hline $\mathrm{CF}$ & Lumacaftor & CFTR corrector $\mathrm{C} 1$ & $\begin{array}{l}\text { Increases the amount of F508del-CFTR that reaches the } \\
\text { cell surface }\end{array}$ & Approved & {$[478,479]$} \\
\hline $\mathrm{CF}$ & Ivacaftor & CFTR potentiator & CF patients possessing a G551D CFTR mutation & Approved & [571] \\
\hline $\mathrm{CF}$ & Orkambi & CFTR corrector $(\mathrm{C} 1)$ & $\begin{array}{l}\text { For patients homozygous for F508del-CFTR; increases the } \\
\text { amount of F508del-CFTR that reaches the cell surface }\end{array}$ & Approved & [480] \\
\hline $\mathrm{CF}$ & Ibuprofen & Cox-1 and Cox-2 & Slows the progression of lung disease in children with $\mathrm{CF}$ & Approved & {$[279,280,496,497]$} \\
\hline $\mathrm{CF}$ & Amelubant & LTB4 receptor antagonist & Eicosanoid modulator; anti-inflammatory activity & Phase 2 & [498] \\
\hline $\mathrm{CF}$ & POL6014 & $\begin{array}{l}\text { Neutrophil elastase function } \\
\text { blocker }\end{array}$ & $\begin{array}{c}\text { Clear inhibition of neutrophil elastase in the sputum of } \\
\text { subjects with CF after single dosing }\end{array}$ & Phase 1 & [502] \\
\hline $\mathrm{CF}$ & CTX-4430 & $\begin{array}{l}\text { Leukotriene A4 hydrolase (LTA4H) } \\
\text { inhibitor. Decreases the production } \\
\text { of LTB4 }\end{array}$ & $\begin{array}{l}\text { LTA4H and LTB4 are strongly associated with the } \\
\text { development of many conditions involving inflammation, } \\
\text { including CF }\end{array}$ & Phase 2 & {$[499,500]$} \\
\hline $\mathrm{CF}$ & JBT-101 & $\begin{array}{l}\text { Selective CB2 agonist. Decreases } \\
\text { neutrophilic inflammation by } \\
\text { inhibiting LTB4 and promotes } \\
\text { resolution of inflammation by } \\
\text { modulation of arachidonic } \\
\text { acid metabolism }\end{array}$ & $\begin{array}{l}\text { Reduction in some sputum inflammatory markers; } \\
\text { reduction of exacerbations in response to lenabasum, with } \\
\text { no serious adverse effects reported }\end{array}$ & $\begin{array}{l}\text { Phase } 2 \text { heading } \\
\text { for Phase } 2 b\end{array}$ & {$[505,507]$} \\
\hline $\mathrm{CF}$ & $\begin{array}{l}\text { Thiazolidinediones } \\
\text { (glitazones) }\end{array}$ & $\begin{array}{l}\text { Inhibition of NF- } \mathrm{KB} \text { activity } \\
\text { through upregulation of } \\
\text { peroxisome proliferator activating } \\
\text { receptor (PPAR) }\end{array}$ & $\begin{array}{l}\text { Reduce systemic inflammation in polymicrobial sepsis by } \\
\text { modulation of signal transduction pathways }\end{array}$ & Approved & [556-558] \\
\hline $\mathrm{CF}$ & $\begin{array}{l}\text { Troglitazone and } \\
\text { ciglitazone }\end{array}$ & PPAR activators & $\begin{array}{c}\text { Reduce production of proinflammatory mediators in } \\
\text { response to P. aeruginosa }\end{array}$ & Approved & [559] \\
\hline $\mathrm{CF}$ & $\alpha 1$-antitrypsin & Serine protease inhibitor & $\begin{array}{c}\text { Suppresses inflammatory markers, including free } \\
\text { neutrophil elastase, proinflammatory cytokines } \\
\text { and neutrophils }\end{array}$ & Phase 2 & [503] \\
\hline $\mathrm{CF}$ & SB-656933 & CXCR2 antagonist & Promising modulator of airway inflammation & Phase 2 & [514] \\
\hline $\mathrm{CF}$ & LAU-7B & Retinoids & $\begin{array}{l}\text { Promotes extracellular matrix homeostasis; safe and } \\
\text { well tolerated. }\end{array}$ & Phase $1 b$ & [527] \\
\hline
\end{tabular}


Table 1. Cont.

\begin{tabular}{|c|c|c|c|c|c|}
\hline Disease & Drug & Target & Biologic Function & Trial & Reference \\
\hline $\mathrm{CF}$ & Lenabasum & Cannabinoid receptor type 2 (CB2) & $\begin{array}{l}\text { CB2 is found primarily on the surfaces of activated } \\
\text { immune cells; upon binding to the CB2 receptors, } \\
\text { lenabasum triggers the production of proinflammatory } \\
\text { mediators, reducing inflammation; reduces the number of } \\
\text { inflammatory cells and inflammatory mediators found in } \\
\text { the sputum; FEV1 was stable throughout the study for } \\
\text { both lenabasum and placebo groups. }\end{array}$ & $\begin{array}{l}\text { Phase } 2 \text {, heading } \\
\text { for } 2 \mathrm{~b}\end{array}$ & [506] \\
\hline CF & GSH & Endogenous antioxidant & Improves lung function and decreases oxidative stress & Phase 2 & [530-533] \\
\hline $\mathrm{CF}$ & $\beta$-carotene & Natural antioxidant & Improves lung function and decreases oxidative stress & Phase 1 & {$[534,535]$} \\
\hline $\mathrm{CF}$ & Deferiprone (L1) & $\begin{array}{l}\text { Chelating drug/pharmaceutical } \\
\text { antioxidant }\end{array}$ & $\begin{array}{l}\text { Used as a main, alternative or adjuvant therapy in many } \\
\text { pathological conditions }\end{array}$ & - & {$[536,537]$} \\
\hline $\mathrm{CF}$ & $\mathrm{N}$-acetyl cysteine & Antioxidant & Inhibits $\mathrm{H}_{2} \mathrm{O}_{2}$ and increases $\mathrm{GSH}$ & Phase $2 b$ & {$[531,538]$} \\
\hline
\end{tabular}


Author Contributions: J.C. wrote and edited the manuscript; J.M.A. wrote and supervised the manuscript. Both authors have read and agree to the published version of the manuscript.

Funding: J.C. is supported by a grant from the "Associació Catalana de Fibrosi Quística". J.M.A. has received support from the Ministerio de Economía y Competitividad (Madrid, Spain) (grants FIS-ISCIII PI13/01490 and PI16/00377, co-funded by FEDER funds/European Regional Development Fund (ERDF)-a way to build Europe-), and from the Generalitat de Catalunya (grant 2017SGR 00291). J.M.A. is sponsored by the "Researchers Consolidation Program" from the SNS-Dpt. Salut Generalitat de Catalunya (Exp. CES06/012).

Conflicts of Interest: The authors report no conflict of interest in this work.

\section{References}

1. Moldoveanu, B.; Otmishi, P.; Jani, P.; Walker, J.; Sarmiento, X.; Guardiola, J.; Saad, M.; Yu, J. Inflammatory mechanisms in the lung. J. Inflamm. Res. 2009, 2, 1-11. [PubMed]

2. García-Bellmunt, L.; Sibilia, O. Mecanismos de defensa pulmonar. Med. Respir. 2013, 6, 15-24.

3. LeMessurier, K.S.; Tiwary, M.; Morin, N.P.; Samarasinghe, A.E. Respiratory Barrier as a Safeguard and Regulator of Defense Against Influenza A Virus and Streptococcus pneumoniae. Front. Immunol. 2020, 11, 3. [CrossRef] [PubMed]

4. Ganesan, S.; Comstock, A.T.; Sajjan, U.S. Barrier function of airway tract epithelium. Tissue Barriers 2013, 1, e24997. [CrossRef] [PubMed]

5. Yuksel, H.; Turkeli, A. Airway epithelial barrier dysfunction in the pathogenesis and prognosis of respiratory tract diseases in childhood and adulthood. Tissue Barriers 2017, 5, e1367458. [CrossRef] [PubMed]

6. Andrani, F.; Aiello, M.; Bertorelli, G.; Crisafulli, E.; Chetta, A. Cough, a vital reflex. Mechanisms, determinants and measurements. Acta Biomed. 2018, 89, 477-480.

7. Nawroth, J.C.; Van Der Does, A.M.; Ryan, A.; Kanso, E. Multiscale mechanics of mucociliary clearance in the lung. Philos. Trans. R. Soc. B Biol. Sci. 2020, 375, 20190160. [CrossRef]

8. Twigg, H.L. Humoral immune defense (antibodies): Recent advances. Proc. Am. Thorac. Soc. 2005, 2, 417-421. [CrossRef]

9. Sheehan, G.; Garvey, A.; Croke, M.; Kavanagh, K. Innate humoral immune defences in mammals and insects: The same, with differences? Virulence 2018, 9, 1625-1639. [CrossRef]

10. Hartl, D.; Tirouvanziam, R.; Laval, J.; Greene, C.M.; Habiel, D.; Sharma, L.; Yildirim, A.Ö.; Dela Cruz, C.S.; Hogaboam, C.M. Innate Immunity of the Lung: From Basic Mechanisms to Translational Medicine. J. Innate Immun. 2018, 10, 487-501. [CrossRef]

11. Hiemstra, P.S.; McCray, P.B.; Bals, R. The innate immune function of airway epithelial cells in inflammatory lung disease. Eur. Respir. J. 2015, 45, 1150-1162. [CrossRef] [PubMed]

12. Aulakh, G.K. Neutrophils in the lung: "The first responders". Cell Tissue Res. 2018, 371, 577-588. [CrossRef]

13. Ramirez, G.A.; Yacoub, M.-R.; Ripa, M.; Mannina, D.; Cariddi, A.; Saporiti, N.; Ciceri, F.; Castagna, A.; Colombo, G.; Dagna, L. Eosinophils from Physiology to Disease: A Comprehensive Review. BioMed Res. Int. 2018, 2018, 9095275. [CrossRef] [PubMed]

14. Chiu, S.; Bharat, A. Role of monocytes and macrophages in regulating immune response following lung transplantation. Curr. Opin. Organ Transplant. 2016, 21, 239-245. [CrossRef] [PubMed]

15. Byrne, A.J.; Mathie, S.A.; Gregory, L.G.; Lloyd, C.M. Pulmonary macrophages: Key players in the innate defence of the airways. Thorax 2015, 70, 1189-1196. [CrossRef] [PubMed]

16. Cong, J.; Wei, H. Natural killer cells in the lungs. Front. Immunol. 2019, 10, 1416. [CrossRef] [PubMed]

17. Erjefält, J.S. Mast cells in human airways: The culprit? Eur. Respir. Rev. 2014, 23, 299-307. [CrossRef] [PubMed]

18. Peters, M.; Peters, K.; Bufe, A. Regulation of lung immunity by dendritic cells: Implications for asthma, chronic obstructive pulmonary disease and infectious disease. Innate Immun. 2019, 25, 326-336. [CrossRef]

19. Kim, H.J.; Kim, C.H.; Kim, M.J.; Ryu, J.H.; Seong, S.Y.; Kim, S.; Lim, S.J.; Holtzman, M.J.; Yoon, J.H. The induction of pattern-recognition receptor expression against influenza a virus through Duox2-derived reactive oxygen species in nasal mucosa. Am. J. Respir. Cell Mol. Biol. 2015, 53, 525-535. [CrossRef]

20. Tengroth, L.; Millrud, C.R.; Kvarnhammar, A.M.; Georén, S.K.; Latif, L.; Cardell, L.O. Functional effects of Toll-Like Receptor (TLR)3, 7, 9, RIG-I and MDA-5 stimulation in nasal epithelial cells. PLoS ONE 2014, 9, e98239. [CrossRef] 
21. El-Zayat, S.R.; Sibaii, H.; Mannaa, F.A. Toll-like receptors activation, signaling, and targeting: An overview. Bull. Natl. Res. Cent. 2019, 43,1-12. [CrossRef]

22. Reynolds, J.M.; Dong, C. Toll-like receptor regulation of effector T lymphocyte function. Trends Immunol. 2013, 34, 511-519. [CrossRef]

23. Taher, T.E.; Bystrom, J.; Ong, V.H.; Isenberg, D.A.; Renaudineau, Y.; Abraham, D.J.; Mageed, R.A. Intracellular B Lymphocyte Signalling and the Regulation of Humoral Immunity and Autoimmunity. Clin. Rev. Allergy Immunol. 2017, 53, 237-264. [CrossRef] [PubMed]

24. Gomes, E.C.; Florida-James, G. Lung Inflammation, Oxidative Stress and Air Pollution. In Lung Inflammation; IntechOpen: London, UK, 2014.

25. Lodovici, M.; Bigagli, E. Oxidative Stress and Air Pollution Exposure. J. Toxicol. 2011, 2011, 487074. [CrossRef] [PubMed]

26. Ozcan, A.; Ogun, M. Biochemistry of Reactive Oxygen and Nitrogen Species. In Basic Principles and Clinical Significance of Oxidative Stress; IntechOpen: London, UK, 2015.

27. Dröse, S.; Brandt, U. Molecular mechanisms of superoxide production by the mitochondrial respiratory chain. Adv. Exp. Med. Biol. 2012, 748, 145-169. [PubMed]

28. Lenaz, G. Mitochondria and reactive oxygen species. Which role in physiology and pathology? Adv. Exp. Med. Biol. 2012, 942, 93-136. [PubMed]

29. Del Río, L.A.; López-Huertas, E. ROS generation in peroxisomes and its role in cell signaling. Plant Cell Physiol. 2016, 57, 1364-1376. [CrossRef]

30. Bae, Y.S.; Oh, H.; Rhee, S.G.; Yoo, Y. Do Regulation of reactive oxygen species generation in cell signaling. Mol. Cells 2011, 32, 491-509. [CrossRef]

31. Tejero, J.; Shiva, S.; Gladwin, M.T. Sources of vascular nitric oxide and reactive oxygen species and their regulation. Physiol. Rev. 2019, 99, 311-379. [CrossRef]

32. Chelombitko, M.A. Role of Reactive Oxygen Species in Inflammation: A Minireview. Mosc. Univ. Biol. Sci. Bull. 2018, 73, 199-202. [CrossRef]

33. Segal, B.H.; Grimm, M.J.; Khan, A.N.H.; Han, W.; Blackwell, T.S. Regulation of innate immunity by NADPH oxidase. Free Radic. Biol. Med. 2012, 53, 72-80. [CrossRef] [PubMed]

34. Mittal, M.; Siddiqui, M.R.; Tran, K.; Reddy, S.P.; Malik, A.B. Reactive oxygen species in inflammation and tissue injury. Antioxid. Redox Signal. 2014, 20, 1126-1167. [CrossRef] [PubMed]

35. van der Vliet, A.; Danyal, K.; Heppner, D.E. Dual oxidase: A novel therapeutic target in allergic disease. Br. J. Pharmacol. 2018, 175, 1401-1418. [CrossRef] [PubMed]

36. Yang, H.T.; Huang, Y.H.; Yang, G.W. Mini review: Immunologic functions of dual oxidases in mucosal systems of vertebrates. Braz. J. Biol. 2019. [CrossRef] [PubMed]

37. Fischer, H. Mechanisms and function of DUOX in epithelia of the lung. Antioxid. Redox Signal. 2009, 11, 2453-2465. [CrossRef]

38. Hu, L.; Zachariae, E.D.; Larsen, U.G.; Vilhardt, F.; Petersen, S.V. The dynamic uptake and release of SOD3 from intracellular stores in macrophages modulates the inflammatory response. Redox Biol. 2019, 26, 101268. [CrossRef]

39. Kinnula, V.L.; Crapo, J.D. Superoxide dismutases in the lung and human lung diseases. Am. J. Respir. Crit. Care Med. 2003, 167, 1600-1619. [CrossRef]

40. Ganguly, K.; Depner, M.; Fattman, C.; Bein, K.; Oury, T.D.; Wesselkamper, S.C.; Borchers, M.T.; Schreiber, M.; Gao, F.; Von Mutius, E.; et al. Superoxide dismutase 3, extracellular (SOD3) variants and lung function. Physiol. Genom. 2009, 37, 260-267. [CrossRef]

41. Petersen, S.V.; Enghild, J.J. Extracellular superoxide dismutase: Structural and functional considerations of a protein shaped by two different disulfide bridge patterns. Biomed. Pharmacother. 2005, 59, 175-182. [CrossRef]

42. Rahman, I.; Biswas, S.K.; Kode, A. Oxidant and antioxidant balance in the airways and airway diseases. Eur. J. Pharmacol. 2006, 533, 222-239. [CrossRef]

43. Han, W.; Fessel, J.P.; Sherrill, T.; Kocurek, E.G.; Yull, F.E.; Blackwell, T.S. Enhanced Expression of Catalase in Mitochondria Modulates NF-kB-Dependent Lung Inflammation through Alteration of Metabolic Activity in Macrophages. J. Immunol. 2020, 205, 1125-1134. [CrossRef] [PubMed] 
44. Yatmaz, S.; Seow, H.J.; Gualano, R.C.; Wong, Z.X.; Stambas, J.; Selemidis, S.; Crack, P.J.; Bozinovski, S.; Anderson, G.P.; Vlahos, R. Glutathione peroxidase-1 reduces influenza A virus-induced lung inflammation. Am. J. Respir. Cell Mol. Biol. 2013, 48, 17-26. [CrossRef] [PubMed]

45. Elko, E.A.; Cunniff, B.; Seward, D.J.; Chia, S.B.; Aboushousha, R.; Van De Wetering, C.; Van Der Velden, J.; Manuel, A.; Shukla, A.; Heintz, N.H.; et al. Peroxiredoxins and Beyond; Redox Systems Regulating Lung Physiology and Disease. Antioxid. Redox Signal. 2019, 31, 1070-1091. [CrossRef] [PubMed]

46. Schremmer, B.; Manevich, Y.; Feinstein, S.I.; Fisher, A.B. Peroxiredoxins in the lung with emphasis on peroxiredoxin VI. Subcell. Biochem. 2007, 44, 317-344.

47. Kinnula, V.L.; Lehtonen, S.; Kaarteenaho-Wiik, R.; Lakari, E.; Pääkkö, P.; Kang, S.W.; Rhee, S.G.; Soini, Y. Cell specific expression of peroxiredoxins in human lung and pulmonary sarcoidosis. Thorax 2002, 57, 157-164. [CrossRef]

48. Park, J.H.; Kim, Y.S.; Lee, H.L.; Shim, J.Y.; Lee, K.S.; Oh, Y.J.; Shin, S.S.; Choi, Y.H.; Park, K.J.; Park, R.W.; et al. Expression of peroxiredoxin and thioredoxin in human lung cancer and paired normal lung. Respirology 2006, 11, 269-275. [CrossRef]

49. Xu, J.; Li, T.; Wu, H.; Xu, T. Role of thioredoxin in lung disease. Pulm. Pharmacol. Ther. 2012, 25, $154-162$. [CrossRef]

50. Netto, L.E.S.; Antunes, F. The Roles of peroxiredoxin and thioredoxin in hydrogen peroxide sensing and in signal transduction. Mol. Cells 2016, 39, 65-71.

51. Nakamura, T.; Nakamura, H.; Hoshino, T.; Ueda, S.; Wada, H.; Yodoi, J. Redox regulation of lung inflammation by thioredoxin. Antioxid. Redox Signal. 2005, 7, 60-71. [CrossRef]

52. Shao, R.; Yang, Y.; Zhang, Y.; Zhao, S.; Zheng, Z.; Chen, G. The expression of thioredoxin-1 and inflammatory cytokines in patients with sepsis. Immunopharmacol. Immunotoxicol. 2020, 42, 280-285. [CrossRef]

53. Janssen-Heininger, Y. Glutathione, Glutaredoxin And S-Glutathionylation In Lung Disease. Free Radic. Biol. Med. 2017, 112, 3. [CrossRef]

54. Chia, S.B.; Elko, E.A.; Aboushousha, R.; Manuel, A.M.; van de Wetering, C.; Druso, J.E.; van der Velden, J.; Seward, D.J.; Anathy, V.; Irvin, C.G.; et al. Dysregulation of the glutaredoxin/S-glutathionylation redox axis in lung diseases. Am. J. Physiol. Cell Physiol. 2020, 318, C304-C327. [CrossRef]

55. Hemilä, H.; Louhiala, P. Vitamin C may affect lung infections. J. R. Soc. Med. 2007, 100, 495-498. [CrossRef] [PubMed]

56. Shaheen, S.O. Antioxidants and respiratory disease: The uric acid paradox. Thorax 2014, 69, 978-979. [CrossRef] [PubMed]

57. Fitzpatrick, A.M.; Jones, D.P.; Brown, L.A.S. Glutathione redox control of asthma: From molecular mechanisms to therapeutic opportunities. Antioxid. Redox Signal. 2012, 17, 375-408. [CrossRef]

58. Gould, N.S.; Min, E.; Gauthier, S.; Martin, R.J.; Day, B.J. Lung glutathione adaptive responses to cigarette smoke exposure. Respir. Res. 2011, 12, 133. [CrossRef] [PubMed]

59. Miyazawa, T.; Burdeos, G.C.; Itaya, M.; Nakagawa, K.; Miyazawa, T. Vitamin E: Regulatory Redox Interactions. IUBMB Life 2019, 71, 430-441. [CrossRef]

60. Cross, C.E.; van der Vliet, A.; O'Neill, C.A.; Louie, S.; Halliwell, B. Oxidants, antioxidants, and respiratory tract lining fluids. Environ. Health Perspect. 1994, 102, 185-191.

61. Behndig, A.F.; Blomberg, A.; Helleday, R.; Duggan, S.T.; Kelly, F.J.; Mudway, I.S. Antioxidant responses to acute ozone challenge in the healthy human airway. Inhal. Toxicol. 2009, 21, 933-942. [CrossRef]

62. Mudway, I.S.; Blomberg, A.; Frew, A.J.; Holgate, S.T.; Sandström, T.; Kelly, F.J. Antioxidant consumption and repletion kinetics in nasal lavage fluid following exposure of healthy human volunteers to ozone. Eur. Respir. J. 1999, 13, 1429-1438. [CrossRef]

63. Barthelemy, J.; Sanchez, K.; Miller, M.R.; Khreis, H. New opportunities to mitigate the burden of disease caused by traffic related air pollution: Antioxidant-rich diets and supplements. Int. J. Environ. Res. Public Health 2020, 17, 630. [CrossRef] [PubMed]

64. Ballinger, C.A.; Cueto, R.; Squadrito, G.; Coffin, J.F.; Velsor, L.W.; Pryor, W.A.; Postlethwait, E.M. Antioxidant-mediated augmentation of ozone-induced membrane oxidation. Free Radic. Biol. Med. 2005, 38, 515-526. [CrossRef] [PubMed]

65. Cho, H.Y.; Reddy, S.P.; Kleeberger, S.R. Nrf2 defends the lung from oxidative stress. Antioxid. Redox Signal. 2006, 8, 76-87. [CrossRef] [PubMed] 
66. Kavian, N.; Mehlal, S.; Jeljeli, M.; Saidu, N.E.B.; Nicco, C.; Cerles, O.; Chouzenoux, S.; Cauvet, A.; Camus, C.; Ait-Djoudi, M.; et al. The Nrf2-antioxidant response element signaling pathway controls fibrosis and autoimmunity in scleroderma. Front. Immunol. 2018, 9, 1896. [CrossRef]

67. Müller, T.; Hengstermann, A. Nrf2: Friend and Foe in preventing cigarette smoking-dependent lung disease. Chem. Res. Toxicol. 2012, 25, 1805-1824. [CrossRef]

68. Osburn, W.O.; Kensler, T.W. Nrf2 signaling: An adaptive response pathway for protection against environmental toxic insults. Mutat. Res. Rev. Mutat. Res. 2008, 659, 31-39. [CrossRef]

69. Aghasafari, P.; George, U.; Pidaparti, R. A review of inflammatory mechanism in airway diseases. Inflamm. Res. 2019, 68, 59-74. [CrossRef]

70. Park, H.S.; Kim, S.R.; Lee, Y.C. Impact of oxidative stress on lung diseases. Respirology 2009, 14, 27-38. [CrossRef]

71. Matthay, M.A.; Zemans, R.L.; Zimmerman, G.A.; Arabi, Y.M.; Beitler, J.R.; Mercat, A.; Herridge, M.; Randolph, A.G.; Calfee, C.S. Acute respiratory distress syndrome. Nat. Rev. Dis. Prim. 2018, 5, 18. [CrossRef]

72. Fernando, S.M.; Cardinal, P.; Brindley, P.G. Hypoxemic Respiratory Failure from Acute Respiratory Distress Syndrome Secondary to Leptospirosis. Case Rep. Crit. Care 2017, 2017, 1-4. [CrossRef]

73. Ashbaugh, D.G.; Bigelow, D.B.; Petty, T.L.; Levine, B.E. Acute respiratory distress in adults. Lancet 1967, 2, 319-323. [CrossRef]

74. Ranieri, V.M.; Rubenfeld, G.D.; Thompson, B.T.; Ferguson, N.D.; Caldwell, E.; Fan, E.; Camporota, L.; Slutsky, A.S. Acute respiratory distress syndrome: The Berlin definition. JAMA J. Am. Med. Assoc. 2012, 307, 2526-2533.

75. Cardinal-Fernandez, P.; Lorente, J.A.; Ballen-Barragan, A.; Matute-Bello, G. Acute respiratory distress syndrome and diffuse alveolar damage new insights on a complex relationship. Ann. Am. Thorac. Soc. 2017, 14, 844-850. [CrossRef]

76. Chiumello, D.; Coppola, S.; Froio, S.; Gotti, M. What's next after ARDS: Long-term outcomes. Respir. Care 2016, 61, 689-699. [CrossRef] [PubMed]

77. Fanelli, V.; Ranieri, V.M. Mechanisms and clinical consequences of acute lung injury. Ann. Am. Thorac. Soc. 2015, 12, S3-S8. [CrossRef] [PubMed]

78. Kellner, M.; Noonepalle, S.; Lu, Q.; Srivastava, A.; Zemskov, E.; Black, S.M. ROS signaling in the pathogenesis of Acute Lung Injury (ALI) and Acute Respiratory Distress Syndrome (ARDS). In Advances in Experimental Medicine and Biology; Springer: New York, NY, USA, 2017; Volume 967, pp. 105-137.

79. Zemans, R.L.; Matthay, M.A. What drives neutrophils to the alveoli in ARDS? Thorax 2017, 72, 1-3. [CrossRef] [PubMed]

80. Potey, P.M.; Rossi, A.G.; Lucas, C.D.; Dorward, D.A. Neutrophils in the initiation and resolution of acute pulmonary inflammation: Understanding biological function and therapeutic potential. J. Pathol. 2019, 247, 672-685. [CrossRef] [PubMed]

81. Allardet-Servent, J.; Forel, J.M.; Roch, A.; Guervilly, C.; Chiche, L.; Castanier, M.; Embriaco, N.; Gainnier, M.; Papazian, L. Fio2 and acute respiratory distress syndrome definition during lung protective ventilation. Crit. Care Med. 2009, 37, 202-207. [CrossRef]

82. Bellani, G.; Laffey, J.G.; Pham, T.; Madotto, F.; Fan, E.; Brochard, L.; Esteban, A.; Gattinoni, L.; Bumbasirevic, V.; Piquilloud, L.; et al. Noninvasive Ventilation of Patients with Acute Respiratory Distress Syndrome: Insights from the LUNG SAFE Study. Am. J. Respir. Crit. Care Med. 2017, 195, 67-77. [CrossRef]

83. Elicker, B.M.; Jones, K.T.; Naeger, D.M.; Frank, J.A. Imaging of Acute Lung Injury. Radiol. Clin. N. Am. 2016, 54, 1119-1132. [CrossRef]

84. Pesenti, A.; Musch, G.; Lichtenstein, D.; Mojoli, F.; Amato, M.B.P.; Cinnella, G.; Gattinoni, L.; Quintel, M. Imaging in acute respiratory distress syndrome. Intensive Care Med. 2016, 42, 686-698. [CrossRef] [PubMed]

85. Rodrigues, R.S.; Bozza, F.A.; Hanrahan, C.J.; Wang, L.M.; Wu, Q.; Hoffman, J.M.; Zimmerman, G.A.; Morton, K.A. 18F-fluoro-2-deoxyglucose PET informs neutrophil accumulation and activation in lipopolysaccharide-induced acute lung injury. Nucl. Med. Biol. 2017, 48, 52-62. [CrossRef] [PubMed]

86. Ma, Y.; Ge, A.; Zhu, W.; Liu, Y.N.; Ji, N.F.; Zha, W.J.; Zhang, J.X.; Zeng, X.N.; Huang, M. Morin attenuates ovalbumin-induced airway inflammation by modulating oxidative stress-responsive MAPK signaling. Oxid. Med. Cell. Longev. 2016, 2016, 5843672. [CrossRef] [PubMed]

87. Lee, K.Y. Pneumonia, acute respiratory distress syndrome, and early immune-modulator therapy. Int. J. Mol. Sci. 2017, 18, 388. [CrossRef] 
88. Keddissi, J.I.; Youness, H.A.; Jones, K.R.; Kinasewitz, G.T. Fluid management in Acute Respiratory Distress Syndrome: A narrative review. Can. J. Respir. Ther. 2019, 50, 1-8. [CrossRef]

89. Quirt, J.; Hildebrand, K.J.; Mazza, J.; Noya, F.; Kim, H. Asthma. Allergy Asthma Clin. Immunol. 2018, 14, 50. [CrossRef]

90. Mims, J.W. Asthma: Definitions and pathophysiology. Int. Forum Allergy Rhinol. 2015, 5, S2-S6. [CrossRef]

91. Bush, A. Pathophysiological mechanisms of asthma. Front. Pediatr. 2019, 7, 68. [CrossRef]

92. Fahy, J.V. Type 2 inflammation in asthma-present in most, absent in many. Nat. Rev. Immunol. 2015, 15, 57-65. [CrossRef]

93. Teran, L.M. CCL chemokines and asthma. Immunol. Today 2000, 21, 235-242. [CrossRef]

94. Xue, L.; Fergusson, J.; Salimi, M.; Panse, I.; Ussher, J.E.; Hegazy, A.N.; Vinall, S.L.; Jackson, D.G.; Hunter, M.G.; Pettipher, R.; et al. Prostaglandin D2 and leukotriene E4 synergize to stimulate diverse TH2 functions and TH2 cell/neutrophil crosstalk. J. Allergy Clin. Immunol. 2015, 135, 1358-1366.e11. [CrossRef] [PubMed]

95. Wu, D.; Zhou, J.; Bi, H.; Li, L.; Gao, W.; Huang, M.; Adcock, I.M.; Barnes, P.J.; Yao, X. CCL11 as a potential diagnostic marker for asthma? J. Asthma 2014, 51, 847-854. [CrossRef] [PubMed]

96. McBrien, C.N.; Menzies-Gow, A. The biology of eosinophils and their role in asthma. Front. Med. $2017,4,93$. [CrossRef] [PubMed]

97. Bowler, R.P.; Crapo, J.D. Oxidative stress in allergic respiratory diseases. J. Allergy Clin. Immunol. 2002, 110, 349-356. [CrossRef]

98. Mishra, V.; Banga, J.; Silveyra, P. Oxidative stress and cellular pathways of asthma and inflammation: Therapeutic strategies and pharmacological targets. Pharmacol. Ther. 2018, 181, 169-182. [CrossRef]

99. Antczak, A.; Kurmanowska, Z.; Kasielski, M.; Nowak, D. Inhaled glucocorticosteroids decrease hydrogen peroxide level in expired air condensate in asthmatic patients. Respir. Med. 2000, 94, 416-421. [CrossRef]

100. Sahiner, U.M.; Birben, E.; Erzurum, S.; Sackesen, C.; Kalayci, O. Oxidative stress in asthma. World Allergy Organ. J. 2011, 4, 151-158. [CrossRef]

101. Gerke, A.K.; Hunninghake, G. The Immunology of Sarcoidosis. Clin. Chest Med. 2008, 29, 379-390. [CrossRef]

102. Lan, N.; Luo, G.; Yang, X.; Cheng, Y.; Zhang, Y.; Wang, X.; Wang, X.; Xie, T.; Li, G.; Liu, Z.; et al. 25-hydroxyvitamin D3-deficiency enhances oxidative stress and corticosteroid resistance in severe asthma exacerbation. PLoS ONE 2014, 9, e111599. [CrossRef] [PubMed]

103. Dworski, R. Oxidant stress in asthma. Thorax 2000, 55, S51-S53. [CrossRef] [PubMed]

104. Arora, P.; Ansari, S.H. Role of Various Mediators in Inflammation of Asthmatic Airways. In Asthma—Biological Evidences; IntechOpen: London, UK, 2019.

105. Qu, J.; Li, Y.; Zhong, W.; Gao, P.; Hu, C. Recent developments in the role of reactive oxygen species in allergic asthma. J. Thorac. Dis. 2017, 9, E32-E43. [CrossRef] [PubMed]

106. Henricks, P.A.J.; Nijkamp, F.P. Reactive oxygen species as mediators in asthma. Pulm. Pharmacol. Ther. 2001, 14, 409-421. [CrossRef] [PubMed]

107. Lambrecht, B.N.; Hammad, H.; Fahy, J.V. The Cytokines of Asthma. Immunity 2019, 50, 975-991. [CrossRef] [PubMed]

108. Rambacher, K.M.; Moniri, N.H. The $\beta 2$-adrenergic receptor-ROS signaling axis: An overlooked component of $\beta 2 A R$ function? Biochem. Pharmacol. 2020, 171, 113690. [CrossRef] [PubMed]

109. Llano-Diez, M.; Sinclair, J.; Yamada, T.; Zong, M.; Fauconnier, J.; Zhang, S.J.; Katz, A.; Jardemark, K.; Westerblad, H.; Andersson, D.C.; et al. The role of reactive oxygen species in $\beta$-adrenergic signaling in cardiomyocytes from mice with the metabolic syndrome. PLoS ONE 2016, 11, e0167090. [CrossRef] [PubMed]

110. Song, X.; Zhao, C.; Dai, C.; Ren, Y.; An, N.; Wen, H.; Pan, L.; Cheng, M.; Zhang, Y. Suppression of the increasing level of acetylcholine-stimulated intracellular $\mathrm{Ca}_{2}{ }^{+}$in guinea pig airway smooth muscle cells by mabuterol. Biomed. Rep. 2015, 3, 778-786. [CrossRef]

111. Tang, W. Role of Airway Smooth Muscle Cells in Asthma Pathology. In Asthma-Biological Evidences; IntechOpen: London, UK, 2019.

112. Jesenak, M.; Zelieskova, M.; Babusikova, E. Oxidative stress and bronchial asthma in children-causes or consequences? Front. Pediatr. 2017, 5, 162. [CrossRef]

113. Cho, Y.S.; Moon, H.B. The role of oxidative stress in the pathogenesis of asthma. Allergy Asthma Immunol. Res. 2010, 2, 183-187. [CrossRef]

114. Rao, R. Oxidative stress-induced disruption of epithelial and endothelial tight junctions. Front. Biosci. 2008, 13, 7210-7226. [CrossRef] 
115. He, P.; Talukder, M.A.H.; Gao, F. Oxidative Stress and Microvessel Barrier Dysfunction. Front. Physiol. 2020, 11, 472. [CrossRef]

116. Wan, W.Y.H.; Hollins, F.; Haste, L.; Woodman, L.; Hirst, R.A.; Bolton, S.; Gomez, E.; Sutcliffe, A.; Desai, D.; Chachi, L.; et al. NADPH Oxidase-4 Overexpression Is Associated with Epithelial Ciliary Dysfunction in Neutrophilic Asthma. Chest 2016, 149, 1445-1459. [CrossRef] [PubMed]

117. Nociari, M.; Ocheretina, O.; Schoggins, J.W.; Falck-Pedersen, E. Sensing Infection by Adenovirus: Toll-Like Receptor-Independent Viral DNA Recognition Signals Activation of the Interferon Regulatory Factor 3 Master Regulator. J. Virol. 2007, 81, 4145-4157. [CrossRef] [PubMed]

118. Guillot, L.; Le Goffic, R.; Bloch, S.; Escriou, N.; Akira, S.; Chignard, M.; Si-Tahar, M. Involvement of Toll-like receptor 3 in the immune response of lung epithelial cells to double-stranded RNA and influenza A virus. J. Biol. Chem. 2005, 280, 5571-5580. [CrossRef]

119. Diebold, S.S.; Kaisho, T.; Hemmi, H.; Akira, S.; Reis E Sousa, C. Innate Antiviral Responses by Means of TLR7-Mediated Recognition of Single-Stranded RNA. Science 2004, 303, 1529-1531. [CrossRef] [PubMed]

120. Kurt-Jones, E.A.; Popova, L.; Kwinn, L.; Haynes, L.M.; Jones, L.P.; Tripp, R.A.; Walsh, E.E.; Freeman, M.W.; Golenbock, D.T.; Anderson, L.J.; et al. Pattern recognition receptors TLR4 and CD14 mediate response to respiratory syncytial virus. Nat. Immunol. 2000, 1, 398-401. [CrossRef]

121. Yao, H.; Yang, S.R.; Kode, A.; Rajendrasozhan, S.; Caito, S.; Adenuga, O.; Henry, R.; Edirisinghe, I.; Rahman, I. Redox regulation of lung inflammation: Role of NADPH oxidase and NF-kB signalling. Biochem. Soc. Trans. 2007, 35, 1151-1155. [CrossRef] [PubMed]

122. Woodland, D.L. Cell-mediated immunity to respiratory virus infections. Curr. Opin. Immunol. 2003, 15, 430-435. [CrossRef]

123. Barrera-Mendoza, C.C.; Ayala-Mata, F.; Cortés-Rojo, C.; García-Pérez, M.E.; Rodríguez-Orozco, A.R. Vitaminas antioxidantes en asma. Rev. Alerg. México 2018, 65, 61. [CrossRef]

124. Comhair, S.; Khan, A.; Erzurum, S. Superoxide dismutase as a longitudinal biomarker of lung function in asthma. Eur. Respir. J. 2011, 38.

125. Janssen-Heininger, Y.; Ckless, K.; Reynaert, N.; Van Der Vliet, A. SOD inactivation in asthma: Bad news or NO news? Am. J. Pathol. 2005, 166, 649-652. [CrossRef]

126. Endaryanto, A.; Hikmah, Z.; Harsono, A. The use of superoxide dismutase in accelerating symptom relief in asthmatic and house dust mite allergic children receiving house dust mite immunotherapy: Double blind randomized controlled clinical trial. Int. J. Integr. Health Sci. 2015, 3, 72-78. [CrossRef]

127. Ghosh, S.; Willard, B.; Comhair, S.A.A.; Dibello, P.; Xu, W.; Shiva, S.; Aulak, K.S.; Kinter, M.; Erzurum, S.C. Disulfide bond as a switch for copper-zinc superoxide dismutase activity in asthma. Antioxid. Redox Signal. 2013, 18, 412-423. [CrossRef] [PubMed]

128. Pittet, J.F.; Griffiths, M.J.D.; Geiser, T.; Kaminski, N.; Dalton, S.L.; Huang, X.; Brown, L.A.S.; Gotwals, P.J.; Koteliansky, V.E.; Matthay, M.A.; et al. TGF- $\beta$ is a critical mediator of acute lung injury. J. Clin. Investig. 2001, 107, 1537-1544. [CrossRef] [PubMed]

129. Comhair, S.A.A.; Xu, W.; Ghosh, S.; Thunnissen, F.B.J.M.; Almasan, A.; Calhoun, W.J.; Janocha, A.J.; Zheng, L.; Hazen, S.L.; Erzurum, S.C. Superoxide dismutase inactivation in pathophysiology of asthmatic airway remodeling and reactivity. Am. J. Pathol. 2005, 166, 663-674. [CrossRef]

130. Comhair, S.A.A.; Erzurum, S.C. Redox control of asthma: Molecular mechanisms and therapeutic opportunities. Antioxid. Redox Signal. 2010, 12, 93-124. [CrossRef] [PubMed]

131. Ghosh, S.; Janocha, A.J.; Aronica, M.A.; Swaidani, S.; Comhair, S.A.A.; Xu, W.; Zheng, L.; Kaveti, S.; Kinter, M.; Hazen, S.L.; et al. Nitrotyrosine Proteome Survey in Asthma Identifies Oxidative Mechanism of Catalase Inactivation. J. Immunol. 2006, 176, 5587-5597. [CrossRef]

132. Bozinovski, S.; Seow, H.J.; Crack, P.J.; Anderson, G.P.; Vlahos, R. Glutathione peroxidase-1 primes pro-inflammatory cytokine production after LPS challenge in vivo. PLoS ONE 2012, 7, e33172. [CrossRef]

133. Won, H.Y.; Sohn, J.H.; Min, H.J.; Lee, K.; Woo, H.A.; Ho, Y.S.; Park, J.W.; Rhee, S.G.; Hwang, E.S. Glutathione peroxidase 1 deficiency attenuates allergen-induced airway inflammation by suppressing th2 and th17 cell development. Antioxid. Redox Signal. 2010, 13, 575-587. [CrossRef]

134. Iorio, A.; Velocci, M.; Graziano, M.E.; Piacentini, S.; Polimanti, R.; Manfellotto, D.; Fuciarelli, M. GPX1*Pro198Leu AND GPX3 rs2070593 as genetic risk markers for Italian asthmatic patients. Clin. Exp. Pharmacol. Physiol. 2016, 43, 277-279. [CrossRef] 
135. Comhair, S.A.A.; Erzurum, S.C. The regulation and role of extracellular glutathione peroxidase. Antioxid. Redox Signal. 2005, 7, 72-79. [CrossRef]

136. Callister, M.E.; Burke-Gaffney, A.; Quinlan, G.J.; Nicholson, A.G.; Florio, R.; Nakamura, H.; Yodoi, J.; Evans, T.W. Extracellular thioredoxin levels are increased in patients with acute lung injury. Thorax 2006, 61, 521-527. [CrossRef]

137. Yamada, Y.; Nakamura, H.; Adachi, T.; Sannohe, S.; Oyamada, H.; Kayaba, H.; Yodoi, J.; Chihara, J. Elevated serum levels of thioredoxin in patients with acute exacerbation of asthma. Immunol. Lett. 2003, 86, 199-205. [CrossRef]

138. Aesif, S.W.; Anathy, V.; Kuipers, I.; Guala, A.S.; Reiss, J.N.; Ho, Y.S.; Janssen-Heininger, Y.M.W. Ablation of glutaredoxin-1 attenuates lipopolysaccharide-induced lung inflammation and alveolar macrophage activation. Am. J. Respir. Cell Mol. Biol. 2011, 44, 491-499. [CrossRef]

139. Kuipers, I.; Louis, R.; Manise, M.; Dentener, M.A.; Irvin, C.G.; Janssen-Heininger, Y.M.W.; Brightling, C.E.; Wouters, E.F.M.; Reynaert, N.L. Increased glutaredoxin-1 and decreased protein S-glutathionylation in sputum of asthmatics. Eur. Respir. J. 2013, 41, 469-472. [CrossRef] [PubMed]

140. Hoffman, S.M.; Tully, J.E.; Lahue, K.G.; Anathy, V.; Nolin, J.D.; Guala, A.S.; van der Velden, J.L.J.; Ho, Y.S.; Aliyeva, M.; Daphtary, N.; et al. Genetic ablation of glutaredoxin-1 causes enhanced resolution of airways hyperresponsiveness and mucus metaplasia in mice with allergic airways disease. Am. J. Physiol. Lung Cell. Mol. Physiol. 2012, 303, L528-L538. [CrossRef] [PubMed]

141. Chung, S.; Sundar, I.K.; Yao, H.; Ho, Y.S.; Rahman, I. Glutaredoxin 1 regulates cigarette smoke-mediated lung inflammation through differential modulation of IKB kinases in mice: Impact on histone acetylation. Am. J. Physiol. Lung Cell. Mol. Physiol. 2010, 299, L192-L203. [CrossRef] [PubMed]

142. Kuipers, I.; Bracke, K.R.; Brusselle, G.G.; Aesif, S.W.; Krijgsman, R.; Arts, I.C.; Wouters, E.F.M.; Reynaert, N.L. Altered cigarette smoke-induced lung inflammation due to Ablation of Grx1. PLoS ONE 2012, 7, e38984. [CrossRef] [PubMed]

143. Hoffman, S.; Nolin, J.; McMillan, D.; Wouters, E.; Janssen-Heininger, Y.; Reynaert, N. Thiol redox chemistry: Role of protein cysteine oxidation and altered redox homeostasis in allergic inflammation and asthma. J. Cell. Biochem. 2015, 116, 884-892. [CrossRef]

144. Fitzpatrick, A.M.; Stephenson, S.T.; Hadley, G.R.; Burwell, L.; Penugonda, M.; Simon, D.M.; Hansen, J.; Jones, D.P.; Brown, L.A.S. Thiol redox disturbances in children with severe asthma are associated with posttranslational modification of the transcription factor nuclear factor (erythroid-derived 2)-like 2. J. Allergy Clin. Immunol. 2011, 127, 1604-1611. [CrossRef]

145. Malhotra, D.; Thimmulappa, R.; Navas-Acien, A.; Sandford, A.; Elliott, M.; Singh, A.; Chen, L.; Zhuang, X.; Hogg, J.; Pare, P.; et al. Decline in NRF2-regulated antioxidants in chronic obstructive pulmonary disease lungs due to loss of its positive regulator, DJ-1. Am. J. Respir. Crit. Care Med. 2008, 178, 592-604. [CrossRef]

146. Liu, Q.; Gao, Y.; Ci, X. Role of Nrf2 and its activators in respiratory diseases. Oxid. Med. Cell. Longev. 2019, 2019. [CrossRef] [PubMed]

147. Fergeson, J.E.; Patel, S.S.; Lockey, R.F.; Fla, T. Acute asthma, prognosis, and treatment. J. Allergy Clin. Immunol. 2017, 139, 438-447. [CrossRef] [PubMed]

148. Castillo, J.R.; Peters, S.P.; Busse, W.W. Asthma Exacerbations: Pathogenesis, Prevention, and Treatment. J. Allergy Clin. Immunol. Pract. 2017, 5, 918-927. [CrossRef] [PubMed]

149. Keskin, O.; Uluca, Ü.; Birben, E.; Coşkun, Y.; Ozkars, M.Y.; Keskin, M.; Kucukosmanoglu, E.; Kalayci, O. Genetic associations of the response to inhaled corticosteroids in children during an asthma exacerbation. Pediatr. Allergy Immunol. 2016, 27, 507-513. [CrossRef] [PubMed]

150. Ökrös, Z.; Endreffy, E.; Novak, Z.; Maroti, Z.; Monostori, P.; Varga, I.S.; Király, A.; Turi, S. Changes in NADPH oxidase mRNA level can be detected in blood at inhaled corticosteroid treated asthmatic children. Life Sci. 2012, 91, 907-911. [CrossRef] [PubMed]

151. Tashkin, D.P.; Lipworth, B.; Brattsand, R. Benefit:Risk Profile of Budesonide in Obstructive Airways Disease. Drugs 2019, 79, 1757-1775. [CrossRef]

152. Gibson, P.G.; Saltos, N.; Borgas, T. Airway mast cells and eosinophils correlate with clinical severity and airway hyperresponsiveness in corticosteroid-treated asthma. J. Allergy Clin. Immunol. 2000, 105, 752-759. [CrossRef]

153. Brightling, C.E.; Green, R.H.; Pavord, I.D. Biomarkers predicting response to corticosteroid therapy in asthma. Treat. Respir. Med. 2005, 4, 309-316. [CrossRef] 
154. Austin, D.; Pouliquen, I.; Keene, O.; Yancey, S. Blood eosinophil dose response to oral corticosteroids in a population of patients with severe asthma. Eur. Respir. J. 2016, 48, PA1110.

155. Domingo, C.; Rello, J.; Sogo, A. As-needed ICS-LABA in Mild Asthma: What Does the Evidence Say? Drugs 2019, 79, 1729-1737. [CrossRef]

156. Johnston, N.W.; Mandhane, P.J.; Dai, J.; Duncan, J.M.; Greene, J.M.; Lambert, K.; Sears, M.R. Attenuation of the September epidemic of asthma exacerbations in children: A randomized, controlled trial of montelukast added to usual therapy. Pediatrics 2007, 120, e702-e712. [CrossRef] [PubMed]

157. Vogelberg, C.; Szefler, S.J.; Vrijlandt, E.J.L.E.; Boner, A.L.; Engel, M.; El Azzi, G.; Vulcu, S.D.; Moroni-Zentgraf, P.M.; Eickmeier, O.; Hamelmann, E.H. Tiotropium add-on therapy is safe and reduces seasonal worsening in paediatric asthma patients. Eur. Respir. J. 2019, 53, 1801824. [CrossRef] [PubMed]

158. Sterling, Y.M. Impact of the Environment on Asthma Control. J. Community Health Nurs. 2012, $29,143-153$. [CrossRef] [PubMed]

159. Donohue, J.F.; Wise, R.; Busse, W.W.; Garfinkel, S.; Zubek, V.B.; Ghafouri, M.; Manuel, R.C.; Schlenker-Herceg, R.; Bleecker, E.R. Efficacy and safety of ipratropium bromide/albuterol compared with albuterol in patients with moderate-to-severe asthma: A randomized controlled trial. BMC Pulm. Med. 2016, 16, 65. [CrossRef] [PubMed]

160. Rodrigo, G.J.; Castro-Rodriguez, J.A. Anticholinergics in the treatment of children and adults with acute asthma: A systematic review with meta-analysis. Thorax 2005, 60, 740-746, Erratum in Thorax 2010, 65, 1118. [CrossRef] [PubMed]

161. Zorc, J.J.; Pusic, M.V.; Ogborn, C.J.; Lebet, R.; Duggan, A.K. Ipratropium bromide added to asthma treatment in the pediatric emergency department. Pediatrics 1999, 103, 748-752. [CrossRef] [PubMed]

162. Rodrigo, G.J. Rapid effects of inhaled corticosteroids in acute asthma: An evidence-based evaluation. Chest 2006, 130, 1301-1311. [CrossRef] [PubMed]

163. Rowe, B.H.; Edmonds, M.L.; Spooner, C.H.; Diner, B.; Camargo, C.A. Corticosteroid therapy for acute asthma. Respir. Med. 2004, 98, 275-284. [CrossRef] [PubMed]

164. Corlateanu, A.; Mendez, Y.; Wang, Y.; de Garnica, R.J.A.; Botnaru, V.; Siafakas, N. Chronic obstructive pulmonary disease and phenotypes: A state-of-the-art. Pulmonology 2020, 26, 95-100. [CrossRef]

165. Rovina, N.; Koutsoukou, A.; Koulouris, N.G. Inflammation and immune response in COPD: Where do we stand? Mediat. Inflamm. 2013, 2013, 413735. [CrossRef]

166. Donnelly, L.E.; Barnes, P.J. Chemokine receptors as therapeutic targets in chronic obstructive pulmonary disease. Trends Pharmacol. Sci. 2006, 27, 546-553. [CrossRef] [PubMed]

167. Barnes, P.J. Cellular and molecular mechanisms of asthma and COPD. Clin. Sci. 2017, 131, 1541-1558. [CrossRef] [PubMed]

168. Traynor, T.R.; Herring, A.C.; Dorf, M.E.; Kuziel, W.A.; Toews, G.B.; Huffnagle, G.B. Differential Roles of CC Chemokine Ligand 2/Monocyte Chemotactic Protein-1 and CCR2 in the Development of T1 Immunity. J. Immunol. 2002, 168, 4659-4666. [CrossRef] [PubMed]

169. Gilowska, I.; Kasper, Ł.; Bogacz, K.; Szczegielniak, J.; Szymasek, T.; Kasper, M.; Czerwinski, M.; Sładek, K.; Majorczyk, E. Impact of Matrix Metalloproteinase 9 on COPD Development in Polish Patients: Genetic Polymorphism, Protein Level, and Their Relationship with Lung Function. BioMed Res. Int. 2018, 2018, 6417415. [CrossRef] [PubMed]

170. Dey, T.; Kalita, J.; Weldon, S.; Taggart, C. Proteases and Their Inhibitors in Chronic Obstructive Pulmonary Disease. J. Clin. Med. 2018, 7, 244. [CrossRef] [PubMed]

171. Ponce-Gallegos, M.A.; Ramírez-Venegas, A.; Falfán-Valencia, R. Th17 profile in COPD exacerbations. Int. J. COPD 2017, 12, 1857-1865. [CrossRef]

172. Lane, N.; Robins, R.A.; Corne, J.; Fairclough, L. Regulation in chronic obstructive pulmonary disease: The role of regulatory T-cells and Th17 cells. Clin. Sci. 2010, 119, 75-86. [CrossRef]

173. Di Stefano, A.; Sangiorgi, C.; Gnemmi, I.; Casolari, P.; Brun, P.; Ricciardolo, F.L.M.; Contoli, M.; Papi, A.; Maniscalco, P.; Ruggeri, P.; et al. TGF- $\beta$ Signaling Pathways in Different Compartments of the Lower Airways of Patients With Stable COPD. Chest 2018, 153, 851-862. [CrossRef]

174. Verhamme, F.M.; Bracke, K.R.; Joos, G.F.; Brusselle, G.G. Transforming growth factor- $\beta$ superfamily in obstructive lung diseases: More suspects than TGF- $\beta$ alone. Am. J. Respir. Cell Mol. Biol. 2015, 52, 653-662. [CrossRef] 
175. Yan, F.; Gao, H.; Zhao, H.; Bhatia, M.; Zeng, Y. Roles of airway smooth muscle dysfunction in chronic obstructive pulmonary disease. J. Transl. Med. 2018, 16, 262. [CrossRef]

176. Zhuan, B.; Yu, Y.; Yang, Z.; Zhao, X.; Li, P. Mechanisms of oxidative stress effects of the NADPH oxidase-ROS-NF- $\mathrm{KB}$ transduction pathway and VPO1 on patients with chronic obstructive pulmonary disease combined with pulmonary hypertension. Eur. Rev. Med. Pharmacol. Sci. 2017, 21, 3459-3464. [PubMed]

177. Meijer, M.; Rijkers, G.T.; Van Overveld, F.J. Neutrophils and emerging targets for treatment in chronic obstructive pulmonary disease. Expert Rev. Clin. Immunol. 2013, 9, 1055-1068. [CrossRef] [PubMed]

178. Klimanov, I.A.; Khaletskaya, A.; Kuznechov, A.; Kontorschikova, K.; Kubysheva, N.; Leonova, D.; Bobkova, A.; Soodaeva, S. Lipid peroxidation in patients with COPD and chronic heart failure. Eur. Respir. J. 2018, 52, PA931.

179. Nicks, M.E.; O'Brien, M.M.; Bowler, R.P. Plasma antioxidants are associated with impaired lung function and COPD exacerbations in smokers. COPD J. Chronic Obstr. Pulm. Dis. 2011, 8, 264-269. [CrossRef] [PubMed]

180. Lomas, D.A. Does protease-antiprotease imbalance explain Chronic obstructive pulmonary disease? Ann. Am. Thorac. Soc. 2016, 13, S130-S137.

181. Fischer, B.M.; Pavlisko, E.; Voynow, J.A. Pathogenic triad in COPD: Oxidative stress, protease-antiprotease imbalance, and inflammation. Int. J. COPD 2011, 6, 413-421. [CrossRef]

182. Turgut, T.; Ilhan, N.; Deveci, F.; Akpolat, N.; Erden, E.S.; Muz, M.H. Glutathione and nitrite levels in induced sputum at COPD patients and healthy smokers. J. Thorac. Dis. 2014, 6, 765-771.

183. Harju, T.; Kaarteenaho-Wiik, R.; Sirviö, R.; Pääkkö, P.; Crapo, J.D.; Oury, T.D.; Soini, Y.; Kinnula, V.L. Manganese superoxide dismutase is increased in the airways of smokers' lungs. Eur. Respir. J. 2004, 24, 765-771. [CrossRef]

184. McGuinness, A.; Sapey, E. Oxidative Stress in COPD: Sources, Markers, and Potential Mechanisms. J. Clin. Med. 2017, 6, 21. [CrossRef]

185. Bentley, A.R.; Emrani, P.; Cassano, P.A. Genetic variation and gene expression in antioxidant related enzymes and risk of COPD: A systematic review. Thorax 2008, 63, 956-961. [CrossRef]

186. Young, R.P.; Hopkins, R.; Black, P.N.; Eddy, C.; Wu, L.; Gamble, G.D.; Mills, G.D.; Garrett, J.E.; Eaton, T.E.; Rees, M.I. Functional variants of antioxidant genes in smokers with COPD and in those with normal lung function. Thorax 2006, 61, 394-399. [CrossRef] [PubMed]

187. Zhou, J.D.; Wang, C.X.; Wu, J.L.; Fukunaga, A.; Cheng, Z.S.; Wang, J.Q.; Yamauchi, A.; Yodoi, J.; Tian, H. Anti-allergic and anti-inflammatory effects and molecular mechanisms of thioredoxin on respiratory system diseases. Antioxid. Redox Signal. 2020, 32, 785-801. [CrossRef] [PubMed]

188. Peltoniemi, M.J.; Rytilä, P.H.; Harju, T.H.; Soini, Y.M.; Salmenkivi, K.M.; Ruddock, L.W.; Kinnula, V.L. Modulation of glutaredoxin in the lung and sputum of cigarette smokers and chronic obstructive pulmonary disease. Respir. Res. 2006, 7, 133. [CrossRef] [PubMed]

189. Estornut, C.; Roger, I.; Ballester, B.; Ribera, P.; Cortijo, J. Activation of nuclear factor erythroid 2-related (Nrf2) system as a novel therapeutic approach in COPD. Eur. Respir. J. 2019, 54, PA4216.

190. Okpechi, S.C.; Ghonim, M.A.; Lammi, M.R. Advances in chronic obstructive pulmonary disease therapy: A vascular-targeted approach. Clin. Med. Insights Ther. 2017, 9, 1179559X1771912. [CrossRef]

191. Vogelmeier, C.F.; Criner, G.J.; Martinez, F.J.; Anzueto, A.; Barnes, P.J.; Bourbeau, J.; Celli, B.R.; Chen, R.; Decramer, M.; Fabbri, L.M.; et al. Global Strategy for the Diagnosis, Management, and Prevention of Chronic Obstructive Lung Disease 2017 Report. GOLD Executive Summary. Am. J. Respir. Crit. Care Med. 2017, 195, 557-582. [CrossRef]

192. Barratt, S.; Creamer, A.; Hayton, C.; Chaudhuri, N. Idiopathic Pulmonary Fibrosis (IPF): An Overview. J. Clin. Med. 2018, 7, 201. [CrossRef]

193. Futosi, K.; Fodor, S.; Mócsai, A. Neutrophil cell surface receptors and their intracellular signal transduction pathways. Int. Immunopharmacol. 2013, 17, 638-650. [CrossRef]

194. Mayadas, T.N.; Cullere, X.; Lowell, C.A. The multifaceted functions of neutrophils. Annu. Rev. Pathol. Mech. Dis. 2014, 9, 181-218. [CrossRef]

195. Mills, C.D. M1 and M2 macrophages: Oracles of health and disease. Crit. Rev. Immunol. 2012, 32, 463-488. [CrossRef]

196. Schupp, J.C.; Binder, H.; Jäger, B.; Cillis, G.; Zissel, G.; Müller-Quernheim, J.; Prasse, A. Macrophage activation in acute exacerbation of idiopathic pulmonary fibrosis. PLoS ONE 2015, 10, e0116775. [CrossRef] [PubMed] 
197. Misharin, A.V.; Morales-Nebreda, L.; Reyfman, P.A.; Cuda, C.M.; Walter, J.M.; McQuattie-Pimentel, A.C.; Chen, C.I.; Anekalla, K.R.; Joshi, N.; Williams, K.J.N.; et al. Monocyte-derived alveolar macrophages drive lung fibrosis and persist in the lung over the life span. J. Exp. Med. 2017, 214, 2387-2404. [CrossRef] [PubMed]

198. Kreuter, M.; Maher, T.M. Can monocytes predict prognosis of idiopathic pulmonary fibrosis? Lancet Respir. Med. 2019, 7, 467-469. [CrossRef]

199. Desai, O.; Winkler, J.; Minasyan, M.; Herzog, E.L. The role of immune and inflammatory cells in idiopathic pulmonary fibrosis. Front. Med. 2018, 5, 43. [CrossRef] [PubMed]

200. Heukels, P.; van Hulst, J.A.C.; van Nimwegen, M.; Boorsma, C.E.; Melgert, B.N.; van den Toorn, L.M.; Boomars, K.A.T.; Wijsenbeek, M.S.; Hoogsteden, H.; von der Thüsen, J.H.; et al. Fibrocytes are increased in lung and peripheral blood of patients with idiopathic pulmonary fibrosis. Respir. Res. 2018, 19, 90. [CrossRef] [PubMed]

201. Maharaj, S.; Shimbori, C.; Kolb, M. Fibrocytes in pulmonary fibrosis: A brief synopsis. Eur. Respir. Rev. 2013, 22, 552-557. [CrossRef]

202. Overed-Sayer, C.; Rapley, L.; Mustelin, T.; Clarke, D.L. Are mast cells instrumental for fibrotic diseases? Front. Pharmacol. 2014, 4, 174. [CrossRef]

203. Komi, D.E.A.; Mortaz, E.; Amani, S.; Tiotiu, A.; Folkerts, G.; Adcock, I.M. The Role of Mast Cells in IgE-Independent Lung Diseases. Clin. Rev. Allergy Immunol. 2020, 58, 377-387. [CrossRef]

204. Marchal-Sommé, J.; Uzunhan, Y.; Marchand-Adam, S.; Valeyre, D.; Soumelis, V.; Crestani, B.; Soler, P. Cutting Edge: Nonproliferating Mature Immune Cells Form a Novel Type of Organized Lymphoid Structure in Idiopathic Pulmonary Fibrosis. J. Immunol. 2006, 176, 5735-5739. [CrossRef]

205. Nuovo, G.J.; Hagood, J.S.; Magro, C.M.; Chin, N.; Kapil, R.; Davis, L.; Marsh, C.B.; Folcik, V.A. The distribution of immunomodulatory cells in the lungs of patients with idiopathic pulmonary fibrosis. Mod. Pathol. 2012, 25, 416-433. [CrossRef]

206. Todd, N.W.; Scheraga, R.G.; Galvin, J.R.; Iacono, A.T.; James Britt, E.; Luzina, I.G.; Burke, A.P.; Atamas, S.P. Lymphocyte aggregates persist and accumulate in the lungs of patients with idiopathic pulmonary fibrosis. J. Inflamm. Res. 2013, 6, 63-70. [CrossRef] [PubMed]

207. Wynn, T.A. Fibrotic disease and the TH1/TH2 paradigm. Nat. Rev. Immunol. 2004, 4, 583-594. [CrossRef] [PubMed]

208. Walker, J.A.; McKenzie, A.N.J. TH2 cell development and function. Nat. Rev. Immunol. 2018, 18, $121-133$. [CrossRef]

209. Saito, A.; Okazaki, H.; Sugawara, I.; Yamamoto, K.; Takizawa, H. Potential action of IL-4 and IL-13 as fibrogenic factors on lung fibroblasts in vitro. Int. Arch. Allergy Immunol. 2003, 132, 168-176. [CrossRef] [PubMed]

210. Keane, M.P.; Belperio, J.A.; Burdick, M.D.; Strieter, R.M. IL-12 attenuates bleomycin-induced pulmonary fibrosis. Am. J. Physiol. Lung Cell. Mol. Physiol. 2001, 281, L92-L97. [CrossRef] [PubMed]

211. Rottoli, P.; Magi, B.; Perari, M.G.; Liberatori, S.; Nikiforakis, N.; Bargagli, E.; Cianti, R.; Bini, L.; Pallini, V. Cytokine profile and proteome analysis in bronchoalveolar lavage of patients with sarcoidosis, pulmonary fibrosis associated with systematic sclerosis and idiopathic pulmonary fibrosis. Proteomics 2005, 5, 1423-1430. [CrossRef]

212. Moore, M.W.; Herzog, E.L. Regulatory T Cells in Idiopathic Pulmonary Fibrosis: Too Much of a Good Thing? Am. J. Pathol. 2016, 186, 1978-1981. [CrossRef]

213. Cheresh, P.; Kim, S.J.; Tulasiram, S.; Kamp, D.W. Oxidative stress and pulmonary fibrosis. Biochim. Biophys. Acta Mol. Basis Dis. 2013, 1832, 1028-1040. [CrossRef]

214. Richter, K.; Kietzmann, T. Reactive oxygen species and fibrosis: Further evidence of a significant liaison. Cell Tissue Res. 2016, 365, 591-605. [CrossRef]

215. Yue, X.; Shan, B.; Lasky, J.A. TGF- $\beta$ : Titan of Lung Fibrogenesis. Curr. Enzym. Inhib. 2010, 6, 1-20. [CrossRef]

216. Liu, R.M.; Desai, L.P. Reciprocal regulation of TGF- $\beta$ and reactive oxygen species: A perverse cycle for fibrosis. Redox Biol. 2015, 6, 565-577. [CrossRef] [PubMed]

217. Kim, Y.M.; Cho, M. Activation of NADPH oxidase subunit NCF4 induces ROS-mediated EMT signaling in HeLa cells. Cell. Signal. 2014, 26, 784-796. [CrossRef] [PubMed] 
218. Amara, N.; Goven, D.; Prost, F.; Muloway, R.; Crestani, B.; Boczkowski, J. NOX4/NADPH oxidase expression is increased in pulmonary fibroblasts from patients with idiopathic pulmonary fibrosis and mediates TGF $\beta 1$-induced fibroblast differentiation into myofibroblasts. Thorax 2010, 65, 733-738. [CrossRef] [PubMed]

219. Hecker, L.; Vittal, R.; Jones, T.; Jagirdar, R.; Luckhardt, T.R.; Horowitz, J.C.; Pennathur, S.; Martinez, F.J.; Thannickal, V.J. NADPH oxidase-4 mediates myofibroblast activation and fibrogenic responses to lung injury. Nat. Med. 2009, 15, 1077-1081. [CrossRef]

220. Sturrock, A.; Cahill, B.; Norman, K.; Huecksteadt, T.P.; Hill, K.; Sanders, K.; Karwande, S.V.; Stringham, J.C.; Bull, D.A.; Gleich, M.; et al. Transforming growth factor- $\beta 1$ induces Nox4 NAD(P)H oxidase and reactive oxygen species-dependent proliferation in human pulmonary artery smooth muscle cells. Am. J. Physiol. Lung Cell. Mol. Physiol. 2006, 290, L661-L673. [CrossRef]

221. Waghray, M.; Cui, Z.; Horowitz, J.C.; Subramanian, I.M.; Martinez, F.J.; Toews, G.B.; Thannickal, V.J. Hydrogen peroxide is a diffusible paracrine signal for the induction of epithelial cell death by activated myofibroblasts. FASEB J. 2005, 19, 1-16. [CrossRef]

222. Koli, K.; Myllärniemi, M.; Keski-Oja, J.; Kinnula, V.L. Transforming growth factor- $\beta$ activation in the lung: Focus on fibrosis and reactive oxygen species. Antioxid. Redox Signal. 2008, 10, 333-342. [CrossRef]

223. Herrera, B.; Murillo, M.M.; Álvarez-Barrientos, A.; Beltrán, J.; Fernández, M.; Fabregat, I. Source of early reactive oxygen species in the apoptosis induced by transforming growth factor- $\beta$ in fetal rat hepatocytes. Free Radic. Biol. Med. 2004, 36, 16-26. [CrossRef]

224. Fois, A.G.; Paliogiannis, P.; Sotgia, S.; Mangoni, A.A.; Zinellu, E.; Pirina, P.; Carru, C.; Zinellu, A. Evaluation of oxidative stress biomarkers in idiopathic pulmonary fibrosis and therapeutic applications: A systematic review. Respir. Res. 2018, 19, 51. [CrossRef]

225. Muramatsu, Y.; Sugino, K.; Ishida, F.; Tatebe, J.; Morita, T.; Homma, S. Effect of inhaled N-acetylcysteine monotherapy on lung function and redox balance in idiopathic pulmonary fibrosis. Respir. Investig. 2016, 54, 170-178. [CrossRef]

226. Bowler, R.P.; Nicks, M.; Warnick, K.; Crapo, J.D. Role of extracellular superoxide dismutase in bleomycin-induced pulmonary fibrosis. Am. J. Physiol. Lung Cell. Mol. Physiol. 2002, 282, L719-L726. [CrossRef] [PubMed]

227. Fattman, C.L.; Chang, L.Y.; Termin, T.A.; Petersen, L.; Enghild, J.J.; Oury, T.D. Enhanced bleomycin-induced pulmonary damage in mice lacking extracellular superoxide dismutase. Free Radic. Biol. Med. 2003, 35, 763-771. [CrossRef]

228. Zelko, I.N.; Zhu, J.; Roman, J. Role of SOD3 in silica-related lung fibrosis and pulmonary vascular remodeling. Respir. Res. 2018, 19, 221. [CrossRef] [PubMed]

229. Mouradian, G.C.; Gaurav, R.; Pugliese, S.; El Kasmi, K.; Hartman, B.; Hernandez-Lagunas, L.; Stenmark, K.R.; Bowler, R.P.; Nozik-Grayck, E. Superoxide dismutase 3 R213G single-nucleotide polymorphism blocks murine bleomycin-induced fibrosis and promotes resolution of inflammation. Am. J. Respir. Cell Mol. Biol. 2017, 56, 362-371. [CrossRef]

230. Kinnula, V.L.; Hodgson, U.A.; Lakari, E.K.; Tan, R.J.; Sormunen, R.T.; Soini, Y.M.; Kakko, S.J.; Laitinen, T.H.; Oury, T.D.; Pääkkö, P.K. Extracellular superoxide dismutase has a highly specific localization in idiopathic pulmonary fibrosis/usual interstitial pneumonia. Histopathology 2006, 49, 66-74. [CrossRef]

231. Tiitto, L.; Kaarteenaho-Wiik, R.; Sormunen, R.; Holmgren, A.; Pääkkö, P.; Soini, Y.; Kinnula, V.L. Expression of the thioredoxin system in interstitial lung disease. J. Pathol. 2003, 201, 363-370. [CrossRef]

232. Iwata, Y.; Okamoto, M.; Hoshino, T.; Kitasato, Y.; Sakazaki, Y.; Tajiri, M.; Matsunaga, K.; Azuma, K.; Kawayama, T.; Kinoshita, T.; et al. Elevated levels of thioredoxin 1 in the lungs and sera of idiopathic pulmonary fibrosis, non-specific interstitial pneumonia and cryptogenic organizing pneumonia. Intern. Med. 2010, 49, 2393-2400. [CrossRef]

233. Richeldi, L.; Davies, H.R.H.R.; Spagnolo, P.; Luppi, F. Corticosteroids for idiopathic pulmonary fibrosis. Cochrane Database Syst. Rev. 2003, CD002880. [CrossRef]

234. Martinez, F.J.; De Andrade, J.A.; Anstrom, K.J.; King, T.E.; Raghu, G. Randomized trial of acetylcysteine in idiopathic pulmonary fibrosis. N. Engl. J. Med. 2014, 370, 2093-2101.

235. Raghu, G.; Anstrom, K.J.; King, T.E.; Lasky, J.A.; Martinez, F.J. Prednisone, azathioprine, and N-acetylcysteine for pulmonary fibrosis. N. Engl. J. Med. 2012, 366, 1968-1977. 
236. Richeldi, L.; Du Bois, R.M.; Raghu, G.; Azuma, A.; Brown, K.K.; Costabel, U.; Cottin, V.; Flaherty, K.R.; Hansell, D.M.; Inoue, Y.; et al. Efficacy and safety of nintedanib in idiopathic pulmonary fibrosis. N. Engl. J. Med. 2014, 370, 2071-2082. [CrossRef] [PubMed]

237. King, T.E.; Bradford, W.Z.; Castro-Bernardini, S.; Fagan, E.A.; Glaspole, I.; Glassberg, M.K.; Gorina, E.; Hopkins, P.M.; Kardatzke, D.; Lancaster, L.; et al. A phase 3 trial of pirfenidone in patients with idiopathic pulmonary fibrosis. N. Engl. J. Med. 2014, 370, 2083-2092. [CrossRef] [PubMed]

238. Yoon, H.Y.; Park, S.; Kim, D.S.; Song, J.W. Efficacy and safety of nintedanib in advanced idiopathic pulmonary fibrosis. Respir. Res. 2018, 19, 203. [CrossRef] [PubMed]

239. Kistler, K.D.; Nalysnyk, L.; Rotella, P.; Esser, D. Lung transplantation in idiopathic pulmonary fibrosis: A systematic review of the literature. BMC Pulm. Med. 2014, 14, 139. [CrossRef] [PubMed]

240. Heukels, P.; Moor, C.C.; von der Thüsen, J.H.; Wijsenbeek, M.S.; Kool, M. Inflammation and immunity in IPF pathogenesis and treatment. Respir. Med. 2019, 147, 79-91. [CrossRef]

241. Vianello, A.; Arcaro, G.; Molena, B.; Turato, C.; Braccioni, F.; Paladini, L.; Vio, S.; Ferrarese, S.; Peditto, P.; Gallan, F.; et al. High-flow nasal cannula oxygen therapy to treat acute respiratory failure in patients with acute exacerbation of idiopathic pulmonary fibrosis. Ther. Adv. Respir. Dis. 2019, 13, 1753466619847130. [CrossRef]

242. Galli, F.; Battistoni, A.; Gambari, R.; Pompella, A.; Bragonzi, A.; Pilolli, F.; Iuliano, L.; Piroddi, M.; Dechecchi, M.C.; Cabrini, G. Oxidative stress and antioxidant therapy in cystic fibrosis. Biochim. Biophys. Acta Mol. Basis Dis. 2012, 1822, 690-713. [CrossRef]

243. Chatterjee, S. Oxidative Stress, Inflammation, and Disease. In Oxidative Stress and Biomaterials; Elsevier: Amsterdam, The Netherlands, 2016; pp. 35-58, ISBN 9780128032701.

244. Koch, C.; Hoiby, N. Pathogenesis of cystic fibrosis. Lancet 1993, 341, 1065-1069. [CrossRef]

245. Cantin, A.M.; Hartl, D.; Konstan, M.W.; Chmiel, J.F. Inflammation in cystic fibrosis lung disease: Pathogenesis and therapy. J. Cyst. Fibros. 2015, 14, 419-430. [CrossRef]

246. Parkins, M.D.; Somayaji, R.; Waters, V.J. Epidemiology, Biology, and Impact of Clonal Pseudomonas aeruginosa Infections in Cystic Fibrosis. Clin. Microbiol. Rev. 2018, 31, e0019-18. [CrossRef]

247. Huang, Y.J.; LiPuma, J.J. The Microbiome in Cystic Fibrosis. Clin. Chest Med. 2016, 37, 59-67. [CrossRef] [PubMed]

248. Turkovic, L.; Caudri, D.; Rosenow, T.; Hall, G.; Stick, S. Presence of mucus plugging is predictive of long term lung function in children with cystic fibrosis. Eur. Respir. J. 2017, 50, OA4401.

249. Rieber, N.; Hector, A.; Carevic, M.; Hartl, D. Current concepts of immune dysregulation in cystic fibrosis. Int. J. Biochem. Cell Biol. 2014, 52, 108-112. [CrossRef] [PubMed]

250. Nichols, D.P.; Chmiel, J.F. Inflammation and its genesis in cystic fibrosis. Pediatr. Pulmonol. 2015, 50, S39-S56. [CrossRef] [PubMed]

251. Sarr, D.; Tóth, E.; Gingerich, A.; Rada, B. Antimicrobial actions of dual oxidases and lactoperoxidase. J. Microbiol. 2018, 56, 373-386. [CrossRef]

252. Rada, B.; Leto, T. Oxidative innate immune defenses by Nox/Duox Family NADPH oxidases. Contrib. Microbiol. 2008, 15, 164-187.

253. Moreau-Marquis, S.; Coutermarsh, B.; Stanton, B.A. Combination of hypothiocyanite and lactoferrin (ALX-109) enhances the ability of tobramycin and aztreonam to eliminate Pseudomonas aeruginosa biofilms growing on cystic fibrosis airway epithelial cells. J. Antimicrob. Chemother. 2015, 70, 160-166. [CrossRef]

254. El-Fakharany, E.M.; Uversky, V.N.; Redwan, E.M. Comparative Analysis of the Antiviral Activity of Camel, Bovine, and Human Lactoperoxidases Against Herpes Simplex Virus Type 1. Appl. Biochem. Biotechnol. 2017, 182, 294-310. [CrossRef]

255. Moskwa, P.; Lorentzen, D.; Excoffon, K.J.D.A.; Zabner, J.; McCray, P.B.; Nauseef, W.M.; Dupuy, C.; Bánfi, B. A novel host defense system of airways is defective in cystic fibrosis. Am. J. Respir. Crit. Care Med. 2007, 175, 174-183. [CrossRef]

256. de Winter-de Groot, K.M.; van der Ent, C.K. Nitric oxide in cystic fibrosis. J. Cyst. Fibros. 2005, 4, 25-29. [CrossRef]

257. Grasemann, H.; Michler, E.; Wallot, M.; Ratjen, F. Decreased concentration of exhaled nitric oxide (NO) in patients with cystic fibrosis. Pediatr. Pulmonol. 1997, 24, 173-177. [CrossRef] 
258. Causer, A.J.; Shute, J.K.; Cummings, M.H.; Shepherd, A.I.; Gruet, M.; Costello, J.T.; Bailey, S.; Lindley, M.; Pearson, C.; Connett, G.; et al. Circulating biomarkers of antioxidant status and oxidative stress in people with cystic fibrosis: A systematic review and meta-analysis. Redox Biol. 2020, 101436. [CrossRef] [PubMed]

259. Fomenko, D.E.; Koc, A.; Agisheva, N.; Jacobsen, M.; Kaya, A.; Malinouski, M.; Rutherford, J.C.; Siu, K.L.; Jin, D.Y.; Winge, D.R.; et al. Thiol peroxidases mediate specific genome-wide regulation of gene expression in response to hydrogen peroxide. Proc. Natl. Acad. Sci. USA 2011, 108, 2729-2734. [CrossRef] [PubMed]

260. Rahman, I. Antioxidant therapies in COPD. Int. J. Chron. Obstruct. Pulmon. Dis. 2006, 1, 15-29. [CrossRef] [PubMed]

261. Zhang, Z.; Leir, S.H.; Harris, A. Oxidative stress regulates CFTR gene expression in human airway epithelial cells through a distal antioxidant response element. Am. J. Respir. Cell Mol. Biol. 2015, 52, 387-396. [CrossRef]

262. Chen, J.; Kinter, M.; Shank, S.; Cotton, C.; Kelley, T.J.; Ziady, A.G. Dysfunction of Nrf-2 in CF epithelia leads to excess intracellular $\mathrm{H} 2 \mathrm{O} 2$ and inflammatory cytokine production. PLoS ONE 2008, 3, e3367. [CrossRef]

263. Hudson, V.M. Rethinking cystic fibrosis pathology: The critical role of abnormal reduced glutathione (GSH) transport caused by CFTR mutation. Free Radic. Biol. Med. 2001, 30, 1440-1461. [CrossRef]

264. Ghezzi, P. Role of glutathione in immunity and inflammation in the lung. Int. J. Gen. Med. 2011, 4, 105-113. [CrossRef]

265. de Bari, L.; Favia, M.; Bobba, A.; Lassandro, R.; Guerra, L.; Atlante, A. Aberrant GSH reductase and NOX activities concur with defective CFTR to pro-oxidative imbalance in cystic fibrosis airways. J. Bioenerg. Biomembr. 2018, 50, 117-129. [CrossRef]

266. Kettle, A.J.; Turner, R.; Gangell, C.L.; Harwood, D.T.; Khalilova, I.S.; Chapman, A.L.; Winterbourn, C.C.; Sly, P.D. Oxidation contributes to low glutathione in the airways of children with cystic fibrosis. Eur. Respir. J. 2014, 44, 122-129. [CrossRef]

267. Sathe, M.N.; Patel, A.S. Update in pediatrics: Focus on fat-soluble vitamins. Nutr. Clin. Pract. 2010, 25, 340-346. [CrossRef] [PubMed]

268. Traber, M.G. The ABCs of vitamin E and $\beta$-carotene absorption. Am. J. Clin. Nutr. 2004, 80, 3-4. [CrossRef]

269. Back, E.I.; Frindt, C.; Nohr, D.; Frank, J.; Ziebach, R.; Stern, M.; Ranke, M.; Biesalski, H.K. Antioxidant deficiency in cystic fibrosis: When is the right time to take action? Am. J. Clin. Nutr. 2004, 80, 374-384. [CrossRef] [PubMed]

270. Wood, Z.A.; Schröder, E.; Harris, J.R.; Poole, L.B. Structure, mechanism and regulation of peroxiredoxins. Trends Biochem. Sci. 2003, 28, 32-40. [CrossRef]

271. Iuliano, L.; Monticolo, R.; Straface, G.; Zullo, S.; Galli, F.; Boaz, M.; Quattrucci, S. Association of cholesterol oxidation and abnormalities in fatty acid metabolism in cystic fibrosis. Am. J. Clin. Nutr. 2009, 90, 477-484. [CrossRef]

272. Gunasekara, L.; Al-Saiedy, M.; Green, F.; Pratt, R.; Bjornson, C.; Yang, A.; Michael Schoel, W.; Mitchell, I.; Brindle, M.; Montgomery, M.; et al. Pulmonary surfactant dysfunction in pediatric cystic fibrosis: Mechanisms and reversal with a lipid-sequestering drug. J. Cyst. Fibros. 2017, 16, 565-572. [CrossRef]

273. Cheer, S.M.; Waugh, J.; Noble, S. Inhaled Tobramycin $\left(\mathrm{TOBI}^{\circledR}\right)$ : A Review of its Use in the Management of Pseudomonas aeruginosa Infections in Patients with Cystic Fibrosis. Drugs 2003, 63, 2501-2520. [CrossRef]

274. Chmiel, J.F.; Konstan, M.W.; Elborn, J.S. Antibiotic and anti-inflammatory therapies for cystic fibrosis. Cold Spring Harb. Perspect. Med. 2013, 3, a009779. [CrossRef]

275. Nichols, D.P.; Durmowicz, A.G.; Field, A.; Flume, P.A.; VanDevanter, D.R.; Mayer-Hamblett, N. Developing inhaled antibiotics in cystic fibrosis: Current challenges and opportunities. Ann. Am. Thorac. Soc. 2019, 16, 534-539. [CrossRef]

276. Moss, R.B. Long-term benefits of inhaled tobramycin in adolescent patients with cystic fibrosis. Chest 2002, 121, 55-63. [CrossRef]

277. Konstan, M.W.; Flume, P.A.; Kappler, M.; Chiron, R.; Higgins, M.; Brockhaus, F.; Zhang, J.; Angyalosi, G.; He, E.; Geller, D.E. Safety, efficacy and convenience of tobramycin inhalation powder in cystic fibrosis patients: The EAGER trial. J. Cyst. Fibros. 2011, 10, 54-61. [CrossRef] [PubMed]

278. Hengzhuang, W.; Green, K.; Pressler, T.; Skov, M.; Katzenstein, T.L.; Wu, X.; Høiby, N. Optimization of colistin dosing regimen for cystic fibrosis patients with chronic Pseudomonas aeruginosa biofilm lung infections. Pediatr. Pulmonol. 2019, 54, 575-580. [CrossRef] [PubMed]

279. Konstan, M.W. Ibuprofen therapy for cystic fibrosis lung disease: Revisited. Curr. Opin. Pulm. Med. 2008, 14, 567-573. [CrossRef] [PubMed] 
280. Lands, L.C.; Stanojevic, S. Oral non-steroidal anti-inflammatory drug therapy for cystic fibrosis. Cochrane Database Syst. Rev. 1999, CD001505. [CrossRef]

281. Köhler, E.; Sollich, V.; Schuster-Wonka, R.; Jorch, G. Lung deposition after electronically breath-controlled inhalation and manually triggered conventional inhalation in cystic fibrosis patients. J. Aerosol Med. Depos. Clear. Eff. Lung 2005, 18, 386-395. [CrossRef]

282. Salvatore, D.; D'Andria, M. Effects of salmeterol on arterial oxyhemoglobin saturations in patients with cystic fibrosis. Pediatr. Pulmonol. 2002, 34, 11-15. [CrossRef]

283. Robinson, M.; Regnis, J.A.; Bailey, D.L.; King, M.; Bautovich, G.J.; Bye, P.T.P. Effect of hypertonic saline, amiloride, and cough on mucociliary clearance in patients with cystic fibrosis. Am. J. Respir. Crit. Care Med. 1996, 153, 1503-1509. [CrossRef]

284. Quan, J.M.; Tiddens, H.A.W.M.; Sy, J.P.; McKenzie, S.G.; Montgomery, M.D.; Robinson, P.J.; Wohl, M.E.B.; Konstan, M.W. A two-year randomized, placebo-controlled trial of dornase alfa in young patients with cystic fibrosis with mild lung function abnormalities. J. Pediatr. 2001, 139, 813-820. [CrossRef]

285. Yang, C.; Montgomery, M. Dornase alfa for cystic fibrosis. Cochrane Database Syst. Rev. 2018, 2018, CD001127. [CrossRef]

286. Shak, S.; Capon, D.J.; Hellmiss, R.; Marsters, S.A.; Baker, C.L. Recombinant human DNase I reduces the viscosity of cystic fibrosis sputum. Proc. Natl. Acad. Sci. USA 1990, 87, 9188-9192. [CrossRef]

287. Aitken, M.L.; Burke, W.; McDonald, G.; Shak, S.; Montgomery, A.B.; Smith, A. Recombinant human DNase inhalation in normal subjects and patients with cystic fibrosis. A phase 1 study. JAMA 1992, 267, 1947-1951. [CrossRef] [PubMed]

288. Hubbard, R.C.; Mcelvaney, N.G.; Birrer, P.; Robinson, W.W.; Jolley, C.; Crystal, R.G.; Shak, S.; Wu, M.; Chernick, M.S. A preliminary study of aerosolized recombinant human deoxyribonuclease $i$ in the treatment of cystic fibrosis. N. Engl. J. Med. 1992, 326, 812-815. [CrossRef] [PubMed]

289. Radtke, T.; Nevitt, S.J.; Hebestreit, H.; Kriemler, S. Physical exercise training for cystic fibrosis. Cochrane Database Syst. Rev. 2017, 2017, CD002768. [CrossRef] [PubMed]

290. Morrison, L.; Milroy, S. Oscillating devices for airway clearance in people with cystic fibrosis. Cochrane Database Syst. Rev. 2020, 2020, CD006842.

291. Shaw, T.D.; McAuley, D.F.; O'Kane, C.M. Emerging drugs for treating the acute respiratory distress syndrome. Expert Opin. Emerg. Drugs 2019, 24, 29-41. [CrossRef] [PubMed]

292. Villar, J.; Ferrando, C.; Martínez, D.; Ambrós, A.; Muñoz, T.; Soler, J.A.; Aguilar, G.; Alba, F.; González-Higueras, E.; Conesa, L.A.; et al. Dexamethasone treatment for the acute respiratory distress syndrome: A multicentre, randomised controlled trial. Lancet Respir. Med. 2020, 8, 267-276. [CrossRef]

293. Villar, J.; Belda, J.; Añón, J.M.; Blanco, J.; Pérez-Méndez, L.; Ferrando, C.; Martínez, D.; Soler, J.A.; Ambrós, A.; Muñoz, T.; et al. Evaluating the efficacy of dexamethasone in the treatment of patients with persistent acute respiratory distress syndrome: Study protocol for a randomized controlled trial. Trials 2016, 17, 342. [CrossRef]

294. Festic, E.; Carr, G.E.; Cartin-Ceba, R.; Hinds, R.F.; Banner-Goodspeed, V.; Bansal, V.; Asuni, A.T.; Talmor, D.; Rajagopalan, G.; Frank, R.D.; et al. Randomized clinical trial of a combination of an inhaled corticosteroid and beta agonist in patients at risk of developing the acute respiratory distress syndrome. Crit. Care Med. 2017, 45, 798-805. [CrossRef]

295. Matthay, M.A.; McAuley, D.F.; Ware, L.B. Clinical trials in acute respiratory distress syndrome: Challenges and opportunities. Lancet Respir. Med. 2017, 5, 524-534. [CrossRef]

296. NCT03096314 Vitamin D to Improve Outcomes by Leveraging Early Treatment. 2017. Available online: https://clinicaltrials.gov/show/NCT03096314 (accessed on 2 May 2020).

297. Parekh, D.; Dancer, R.C.A.; Scott, A.; D’Souza, V.K.; Howells, P.A.; Mahida, R.Y.; Tang, J.C.Y.; Cooper, M.S.; Fraser, W.D.; Tan, L.C.; et al. Vitamin D to Prevent Lung Injury Following Esophagectomy-A Randomized, Placebo-Controlled Trial. Crit. Care Med. 2018, 46, e1128-e1135. [CrossRef]

298. Ginde, A.A.; Brower, R.G.; Caterino, J.M.; Finck, L.; Banner-Goodspeed, V.M.; Grissom, C.K.; Hayden, D.; Hough, C.L.; Hyzy, R.C.; Khan, A.; et al. Early high-dose Vitamin D3 for critically ill, Vitamin D-deficient patients. N. Engl. J. Med. 2019, 381, 2529-2540. [PubMed]

299. Toner, P.; McAuley, D.F.; Shyamsundar, M. Aspirin as a potential treatment in sepsis or acute respiratory distress syndrome. Crit. Care 2015, 19, 374. [CrossRef] [PubMed] 
300. Harr, J.N.; Moore, E.E.; Johnson, J.; Chin, T.L.; Wohlauer, M.V.; Maier, R.; Cuschieri, J.; Sperry, J.; Banerjee, A.; Silliman, C.C.; et al. Antiplatelet therapy is associated with decreased transfusion-associated risk of lung dysfunction, multiple organ failure, and mortality in trauma patients. Crit. Care Med. 2013, 41, 399-404. [CrossRef] [PubMed]

301. Hamid, U.; Krasnodembskaya, A.; Fitzgerald, M.; Shyamsundar, M.; Kissenpfennig, A.; Scott, C.; Lefrancais, E.; Looney, M.R.; Verghis, R.; Scott, J.; et al. Aspirin reduces lipopolysaccharide-induced pulmonary inflammation in human models of ARDS. Thorax 2017, 72, 971-980. [CrossRef] [PubMed]

302. Matthay, M.A.; Calfee, C.S.; Zhuo, H.; Thompson, B.T.; Wilson, J.G.; Levitt, J.E.; Rogers, A.J.; Gotts, J.E.; Wiener-Kronish, J.P.; Bajwa, E.K.; et al. Treatment with allogeneic mesenchymal stromal cells for moderate to severe acute respiratory distress syndrome (START study): A randomised phase 2a safety trial. Lancet Respir. Med. 2019, 7, 154-162. [CrossRef]

303. Fisher, B.J.; Kraskauskas, D.; Martin, E.J.; Farkas, D.; Wegelin, J.A.; Brophy, D.; Ward, K.R.; Voelkel, N.F.; Fowler, A.A.; Natarajan, R. Mechanisms of attenuation of abdominal sepsis induced acute lung injury by ascorbic acid. Am. J. Physiol. Lung Cell. Mol. Physiol. 2012, 303, L20-L32. [CrossRef] [PubMed]

304. NCT02106975 Vitamin C Infusion for Treatment in Sepsis Induced Acute Lung Injury-Full Text View-ClinicalTrials.gov. 2019. Available online: https://clinicaltrials.gov/show/NCT02106975 (accessed on 20 September 2020).

305. Fowler, A.A.; Truwit, J.D.; Hite, R.D.; Morris, P.E.; Dewilde, C.; Priday, A.; Fisher, B.; Thacker, L.R.; Natarajan, R.; Brophy, D.F.; et al. Effect of Vitamin C Infusion on Organ Failure and Biomarkers of Inflammation and Vascular Injury in Patients with Sepsis and Severe Acute Respiratory Failure: The CITRIS-ALI Randomized Clinical Trial. JAMA J. Am. Med. Assoc. 2019, 322, 1261-1270. [CrossRef]

306. Dixon, B.; Schultz, M.J.; Smith, R.; Fink, J.B.; Santamaria, J.D.; Campbell, D.J. Nebulized heparin is associated with fewer days of mechanical ventilation in critically ill patients: A randomized controlled trial. Crit. Care 2010, 14, R180. [CrossRef]

307. ACTRN12612000418875 A Multi-Centre Randomised, Placebo Controlled Trial of Nebulised Heparin in Patients with or at Risk of Developing Acute Respiratory Distress Syndrome, to Determine if Nebulised Heparin Improves Long Term Physical Function. Australian New Zealand Clinical Trials Registry. 2012. Available online: https://www.anzctr.org.au/Trial/Registration/TrialReview.aspx?id=362354 (accessed on 25 September 2020).

308. Morris, P.E.; Steingrub, J.S.; Huang, B.Y.; Tang, S.; Liu, P.M.; Rhode, P.R.; Wong, H.C. A phase I study evaluating the pharmacokinetics, safety and tolerability of an antibody-based tissue factor antagonist in subjects with acute lung injury or acute respiratory distress syndrome. BMC Pulm. Med. 2012, 12, 5. [CrossRef]

309. NCT00879606 Anti-TF Antibody (ALT-836) to Treat Septic Patients With Acute Lung Injury or Acute Respiratory Distress Syndrome-Full Text View—ClinicalTrials.gov. 2015. Available online: https://clinicaltrials.gov/sho w/NCT00879606 (accessed on 2 May 2020).

310. Denham, W.; Yang, J.; Norman, J.; Wang, H.; Botchkina, G.; Tracey, K.J. Inhibition of p38 mitogen activate kinase attenuates the severity of pancreatitis-induced adult respiratory distress syndrome. Crit. Care Med. 2000, 28, 2567-2572. [CrossRef]

311. Christie, J.D.; Vaslef, S.; Chang, P.K.; May, A.K.; Gunn, S.R.; Yang, S.; Hardes, K.; Kahl, L.; Powley, W.M.; Lipson, D.A.; et al. A Randomized Dose-Escalation Study of the Safety and Anti-Inflammatory Activity of the p38 Mitogen-Activated Protein Kinase Inhibitor Dilmapimod in Severe Trauma Subjects at Risk for Acute Respiratory Distress Syndrome. Crit. Care Med. 2015, 43, 1859-1869. [CrossRef] [PubMed]

312. Tagami, T.; Tosa, R.; Omura, M.; Fukushima, H.; Kaneko, T.; Endo, T.; Rinka, H.; Murai, A.; Yamaguchi, J.; Yoshikawa, K.; et al. Effect of a selective neutrophil elastase inhibitor on mortality and ventilator-free days in patients with increased extravascular lung water: A post hoc analysis of the PiCCO Pulmonary Edema Study. J. Intensive Care 2014, 2, 67. [CrossRef] [PubMed]

313. Kido, T.; Muramatsu, K.; Yatera, K.; Asakawa, T.; Otsubo, H.; Kubo, T.; Fujino, Y.; Matsuda, S.; Mayumi, T.; Mukae, H. Efficacy of early sivelestat administration on acute lung injury and acute respiratory distress syndrome. Respirology 2017, 22, 708-713. [CrossRef] [PubMed]

314. Pu, S.; Wang, D.; Liu, D.; Zhao, Y.; Qi, D.; He, J.; Zhou, G. Effect of sivelestat sodium in patients with acute lung injury or acute respiratory distress syndrome: A meta-analysis of randomized controlled trials. BMC Pulm. Med. 2017, 17, 148. [CrossRef] [PubMed] 
315. Cao, Y.Z.; Tu, Y.Y.; Chen, X.; Wang, B.L.; Zhong, Y.X.; Liu, M.H. Protective effect of Ulinastatin against murine models of sepsis: Inhibition of TNF- $\alpha$ and IL-6 and augmentation of IL-10 and IL-13. Exp. Toxicol. Pathol. 2012, 64, 543-547. [CrossRef] [PubMed]

316. Leng, Y.-X. Ulinastatin for acute lung injury and acute respiratory distress syndrome: A systematic review and meta-analysis. World J. Crit. Care Med. 2014, 3, 34. [CrossRef]

317. NCT02895191 The Safety and Dose Response Relationship of Ulinastatin for Acute Respiratory Distress Syndrome(ARDS)—Full Text View-ClinicalTrials.gov. 2018. Available online: https://clinicaltrials.gov/sho w/NCT02895191 (accessed on 2 May 2020).

318. Paine, R.; Standiford, T.J.; Dechert, R.E.; Moss, M.; Martin, G.S.; Rosenberg, A.L.; Thannickal, V.J.; Burnham, E.L.; Brown, M.B.; Hyzy, R.C. A randomized Trial of recombinant human granulocyte-macrophage colony stimulating factor for Patients with acute lung injury. Crit. Care Med. 2012, 40, 90-97. [CrossRef]

319. Frevert, C.W.; Matute-Bello, G.; Skerrett, S.J.; Goodman, R.B.; Kajikawa, O.; Sittipunt, C.; Martin, T.R. Effect of CD14 Blockade in Rabbits with Escherichia coli Pneumonia and Sepsis. J. Immunol. 2000, 164, 5439-5445. [CrossRef]

320. NCT03017547 A Phase 2 Study of IC14 in Acute Respiratory Distress Syndrome-Full Text View-ClinicalTrials.gov. 2019. Available online: https://clinicaltrials.gov/show/NCT03017547 (accessed on 2 May 2020).

321. Fuller, B.M.; Mohr, N.M.; Skrupky, L.; Fowler, S.; Kollef, M.H.; Carpenter, C.R. The use of inhaled prostaglandins in patients with ARDS: A systematic review and meta-analysis. Chest 2015, 147, 1510-1522. [CrossRef]

322. Bosmann, M.; Grailer, J.J.; Ruemmler, R.; Russkamp, N.F.; Zetoune, F.S.; Sarma, J.V.; Standiford, T.J.; Ward, P.A. Extracellular histones are essential effectors of C5aR- and C5L2-mediated tissue damage and inflammation in acute lung injury. FASEB J. 2013, 27, 5010-5021. [CrossRef]

323. Wildhagen, K.C.A.A.; De Frutos, P.G.; Reutelingsperger, C.P.; Schrijver, R.; Aresté, C.; Ortega-Gómez, A.; Deckers, N.M.; Hemker, H.C.; Soehnlein, O.; Nicolaes, G.A.F. Nonanticoagulant heparin prevents histone-mediated cytotoxicity in vitro and improves survival in sepsis. Blood 2014, 123, 1098-1101. [CrossRef] [PubMed]

324. Kalliolias, G.D.; Liossis, S.N.C. The future of the IL-1 receptor antagonist anakinra: From rheumatoid arthritis to adult-onset still's disease and systemic-onset juvenile idiopathic arthritis. Expert Opin. Investig. Drugs 2008, 17, 349-359. [CrossRef] [PubMed]

325. Liu, D.; Lon, H.K.; DuBois, D.C.; Almon, R.R.; Jusko, W.J. Population pharmacokinetic-pharmacodynamic-disease progression model for effects of anakinra in Lewis rats with collagen-induced arthritis. J. Pharmacokinet. Pharmacodyn. 2011, 38, 769-786. [CrossRef] [PubMed]

326. Patel, V.J.; Biswas Roy, S.; Mehta, H.J.; Joo, M.; Sadikot, R.T. Alternative and Natural Therapies for Acute Lung Injury and Acute Respiratory Distress Syndrome. Biomed Res. Int. 2018, 2018, 2476824. [CrossRef]

327. Wechsler, M.E. Current and emerging biologic therapies for asthma and copd. Respir. Care 2018, 63, 699-707. [CrossRef] [PubMed]

328. Calhoun, K.H. Asthma treatments: New and emerging therapies. Int. Forum Allergy Rhinol. 2015, 5, S76-S81. [CrossRef]

329. Durham, A.L.; Caramori, G.; Chung, K.F.; Adcock, I.M. Targeted anti-inflammatory therapeutics in asthma and chronic obstructive lung disease. Transl. Res. 2016, 167, 192-203. [CrossRef]

330. Tashkin, D.P.; Wechsler, M.E. Role of eosinophils in airway inflammation of chronic obstructive pulmonary disease. Int. J. COPD 2018, 13, 335-349. [CrossRef]

331. Corren, J.; Casale, T.; Deniz, Y.; Ashby, M. Omalizumab, a recombinant humanized anti-IgE antibody, reduces asthma-related emergency room visits and hospitalizations in patients with allergic asthma. J. Allergy Clin. Immunol. 2003, 111, 87-90. [CrossRef]

332. Cowan, D.C.; Taylor, D.R.; Peterson, L.E.; Cowan, J.O.; Palmay, R.; Williamson, A.; Hammel, J.; Erzurum, S.C.; Hazen, S.L.; Comhair, S.A.A. Biomarker-based asthma phenotypes of corticosteroid response. J. Allergy Clin. Immunol. 2015, 135, 877-883.e1. [CrossRef]

333. Fajt, M.L.; Wenzel, S.E. Biologic therapy in asthma: Entering the new age of personalized medicine. J. Asthma 2014, 51, 669-676. [CrossRef] [PubMed]

334. Apter, A.J. Advances in adult asthma diagnosis and treatment in 2014. J. Allergy Clin. Immunol. 2015, 135, 46-53. [CrossRef] [PubMed] 
335. Ortega, H.G.; Liu, M.C.; Pavord, I.D.; Brusselle, G.G.; FitzGerald, J.M.; Chetta, A.; Humbert, M.; Katz, L.E.; Keene, O.N.; Yancey, S.W.; et al. Mepolizumab treatment in patients with severe eosinophilic asthma. N. Engl. J. Med. 2014, 371, 1198-1207. [CrossRef] [PubMed]

336. Albers, F.C.; Hozawa, S.; Bratton, D.J.; Yancey, S.W.; Prazma, C.M.; Humbert, M.; Liu, M.C. Update: Mepolizumab treatment in patients with severe eosinophilic asthma and prior omalizumab use. Allergy Eur. J. Allergy Clin. Immunol. 2020, 75, 942-946. [CrossRef] [PubMed]

337. Flood-Page, P.T.; Menzies-Gow, A.N.; Kay, A.B.; Robinson, D.S. Eosinophil's role remains uncertain as anti-interleukin-5 only partially depletes numbers in asthmatic airway. Am. J. Respir. Crit. Care Med. 2003, 167, 199-204. [CrossRef]

338. Haldar, P.; Brightling, C.E.; Singapuri, A.; Hargadon, B.; Gupta, S.; Monteiro, W.; Bradding, P.; Green, R.H.; Wardlaw, A.J.; Ortega, H.; et al. Outcomes after cessation of mepolizumab therapy in severe eosinophilic asthma: A 12-month follow-up analysis. J. Allergy Clin. Immunol. 2014, 133, 921-923. [CrossRef] [PubMed]

339. Castro, M.; Zangrilli, J.; Wechsler, M.E.; Bateman, E.D.; Brusselle, G.G.; Bardin, P.; Murphy, K.; Maspero, J.F.; O'Brien, C.; Korn, S. Reslizumab for inadequately controlled asthma with elevated blood eosinophil counts: Results from two multicentre, parallel, double-blind, randomised, placebo-controlled, phase 3 trials. Lancet Respir. Med. 2015, 3, 355-366. [CrossRef]

340. Castro, M.; King, T.S.; Kunselman, S.J.; Cabana, M.D.; Denlinger, L.; Holguin, F.; Kazani, S.D.; Moore, W.C.; Moy, J.; Sorkness, C.A.; et al. Effect of vitamin D3 on asthma treatment failures in adults with symptomatic asthma and lower vitamin D levels: The VIDA randomized clinical trial. JAMA J. Am. Med. Assoc. 2014, 311, 2083-2091. [CrossRef]

341. Ibrahim, H.; O'Sullivan, R.; Casey, D.; Murphy, J.; MacSharry, J.; Plant, B.J.; Murphy, D.M. The effectiveness of Reslizumab in severe asthma treatment: A real-world experience. Respir. Res. 2019, 20, 289. [CrossRef]

342. Christian Virchow, J.; McDonald, M.; Garin, M.; Korn, S. Reslizumab as add-on therapy in patients with refractory asthma. BMJ Open Respir. Res. 2020, 7, e000494. [CrossRef]

343. Markham, A. Benralizumab: First Global Approval. Drugs 2018, 78, 505-511. [CrossRef] [PubMed]

344. Saco, T.V.; Pepper, A.N.; Lockey, R.F. Benralizumab for the treatment of asthma. Expert Rev. Clin. Immunol. 2017, 13, 405-413. [CrossRef] [PubMed]

345. Bleecker, E.R.; FitzGerald, J.M.; Chanez, P.; Papi, A.; Weinstein, S.F.; Barker, P.; Sproule, S.; Gilmartin, G.; Aurivillius, M.; Werkström, V.; et al. Efficacy and safety of benralizumab for patients with severe asthma uncontrolled with high-dosage inhaled corticosteroids and long-acting $\beta 2$-agonists (SIROCCO): A randomised, multicentre, placebo-controlled phase 3 trial. Lancet 2016, 388, 2115-2127. [CrossRef]

346. Nair, P.; Wenzel, S.; Rabe, K.F.; Bourdin, A.; Lugogo, N.L.; Kuna, P.; Barker, P.; Sproule, S.; Ponnarambil, S.; Goldman, M. Oral glucocorticoid-sparing effect of benralizumab in severe asthma. N. Engl. J. Med. 2017, 376, 2448-2458. [CrossRef] [PubMed]

347. Shirley, M. Dupilumab: First Global Approval. Drugs 2017, 77, 1115-1121. [CrossRef] [PubMed]

348. Rabe, K.F.; Nair, P.; Brusselle, G.; Maspero, J.F.; Castro, M.; Sher, L.; Zhu, H.; Hamilton, J.D.; Swanson, B.N.; Khan, A.; et al. Efficacy and safety of dupilumab in glucocorticoid-dependent severe asthma. N. Engl. J. Med. 2018, 378, 2475-2485. [CrossRef]

349. Castro, M.; Corren, J.; Pavord, I.D.; Maspero, J.; Wenzel, S.; Rabe, K.F.; Busse, W.W.; Ford, L.; Sher, L.; FitzGerald, J.M.; et al. Dupilumab Efficacy and Safety in Moderate-to-Severe Uncontrolled Asthma. N. Engl. J. Med. 2018, 378, 2486-2496. [CrossRef]

350. Hanania, N.A.; Korenblat, P.; Chapman, K.R.; Bateman, E.D.; Kopecky, P.; Paggiaro, P.; Yokoyama, A.; Olsson, J.; Gray, S.; Holweg, C.T.J.; et al. Efficacy and safety of lebrikizumab in patients with uncontrolled asthma (LAVOLTA I and LAVOLTA II): Replicate, phase 3, randomised, double-blind, placebo-controlled trials. Lancet Respir. Med. 2016, 4, 781-796. [CrossRef]

351. Brightling, C.E.; Chanez, P.; Leigh, R.; O’Byrne, P.M.; Korn, S.; She, D.; May, R.D.; Streicher, K.; Ranade, K.; Piper, E. Efficacy and safety of tralokinumab in patients with severe uncontrolled asthma: A randomised, double-blind, placebo-controlled, phase $2 \mathrm{~b}$ trial. Lancet Respir. Med. 2015, 3, 692-701. [CrossRef]

352. Korenblat, P.; Kerwin, E.; Leshchenko, I.; Yen, K.; Holweg, C.T.J.; Anzures-Cabrera, J.; Martin, C.; Putnam, W.S.; Governale, L.; Olsson, J.; et al. Efficacy and safety of lebrikizumab in adult patients with mild-to-moderate asthma not receiving inhaled corticosteroids. Respir. Med. 2018, 134, 143-149. [CrossRef] 
353. Busse, W.W.; Brusselle, G.G.; Korn, S.; Kuna, P.; Magnan, A.; Cohen, D.; Bowen, K.; Piechowiak, T.; Wang, M.M.; Colice, G. Tralokinumab did not demonstrate oral corticosteroid-sparing effects in severe asthma. Eur. Respir. J. 2019, 53, 1800948. [CrossRef] [PubMed]

354. NCT03927157 Study to Evaluate Tezepelumab in Adults With Severe Uncontrolled Asthma-Full Text View-ClinicalTrials.gov. 2020. Available online: https://clinicaltrials.gov/show/NCT03927157 (accessed on 2 May 2020).

355. Marone, G.; Spadaro, G.; Braile, M.; Poto, R.; Criscuolo, G.; Pahima, H.; Loffredo, S.; Levi-Schaffer, F.; Varricchi, G. Tezepelumab: A novel biological therapy for the treatment of severe uncontrolled asthma. Expert Opin. Investig. Drugs 2019, 28, 931-940. [CrossRef] [PubMed]

356. Ding, W.; Zou, G.L.; Zhang, W.; Lai, X.N.; Chen, H.W.; Xiong, L.X. Interleukin-33: Its emerging role in allergic diseases. Molecules 2018, 23, 1665. [CrossRef] [PubMed]

357. Busse, W.W.; Holgate, S.; Kerwin, E.; Chon, Y.; Feng, J.; Lin, J.; Lin, S. Study of Brodalumab, a Human Anti IL-17 Receptor Monoclonal Antibody, in Moderate to Severe Asthma. Am. J. Respir. Crit. Care Med. 2013, 188, 1294-1302. [CrossRef] [PubMed]

358. Nair, P.; Gaga, M.; Zervas, E.; Alagha, K.; Hargreave, F.E.; O’Byrne, P.M.; Stryszak, P.; Gann, L.; Sadeh, J.; Chanez, P. Safety and efficacy of a CXCR2 antagonist in patients with severe asthma and sputum neutrophils: A randomized, placebo-controlled clinical trial. Clin. Exp. Allergy 2012, 42, 1097-1103. [CrossRef] [PubMed]

359. NCT00632502 Neutrophilic Asthma Study With Navarixin(MK-7123, SCH527123) (MK-7123-017)(COMPLETED)— Full Text View-ClinicalTrials.gov. 2019. Available online: https://clinicaltrials.gov/show/NCT00632502 (accessed on 2 May 2020).

360. Imaoka, H.; Campbell, H.; Babirad, I.; Watson, R.M.; Mistry, M.; Sehmi, R.; Gauvreau, G.M. TPI ASM8 reduces eosinophil progenitors in sputum after allergen challenge. Clin. Exp. Allergy 2011, 41, 1740-1746. [CrossRef]

361. Cahill, K.N.; Katz, H.R.; Cui, J.; Lai, J.; Kazani, S.; Crosby-Thompson, A.; Garofalo, D.; Castro, M.; Jarjour, N.; DiMango, E.; et al. KIT inhibition by imatinib in patients with severe refractory asthma. N. Engl. J. Med. 2017, 376, 1911-1920. [CrossRef]

362. Howarth, P.H.; Babu, K.S.; Arshad, H.S.; Lau, L.; Buckley, M.; McConnell, W.; Beckett, P.; Al Ali, M.; Chauhan, A.; Wilson, S.J.; et al. Tumour necrosis factor $(\mathrm{TNF} \alpha)$ as a novel therapeutic target in symptomatic corticosteroid dependent asthma. Thorax 2005, 60, 1012-1018. [CrossRef]

363. Oliveri, C.; Polosa, R. Etanercept in chronic severe asthma. Thorax 2006, 61, 640.

364. Holgate, S.T.; Noonan, M.; Chanez, P.; Busse, W.; Dupont, L.; Pavord, I.; Hakulinen, A.; Paolozzi, L.; Wajdula, J.; Zang, C.; et al. Efficacy and safety of etanercept in moderate-to-severe asthma: A randomised, controlled trial. Eur. Respir. J. 2011, 37, 1352-1359. [CrossRef]

365. Morjaria, J.B.; Chauhan, A.J.; Babu, K.S.; Polosa, R.; Davies, D.E.; Holgate, S.T. The role of a soluble $\mathrm{TNF} \alpha$ receptor fusion protein (etanercept) in corticosteroid refractory asthma: A double blind, randomised, placebo controlled trial. Thorax 2008, 63, 584-591. [CrossRef]

366. Zhu, L.-Y.; Ni, Z.-H.; Luo, X.-M.; Wang, X.-B. Advance of antioxidants in asthma treatment. World J. Respirol. 2017, 7, 17. [CrossRef]

367. Bray, T.M.; Bettger, W.J. The physiological role of zinc as an antioxidant. Free Radic. Biol. Med. 1990, 8, 281-291. [CrossRef]

368. Machlin, L.J.; Bendich, A. Free radical tissue damage: Protective role of antioxidant nutrients. FASEB J. 1987, 1, 441-445. [CrossRef] [PubMed]

369. Wood, L.G.; Garg, M.L.; Smart, J.M.; Scott, H.A.; Barker, D.; Gibson, P.G. Manipulating antioxidant intake in asthma: A randomized controlled trial1-3. Am. J. Clin. Nutr. 2012, 96, 534-543. [CrossRef]

370. Kurti, S.P.; Rosenkranz, S.K.; Chapes, S.K.; Teeman, C.S.; Cull, B.J.; Emerson, S.R.; Levitt, M.H.; Smith, J.R.; Harms, C.A. Does chronic physical activity level modify the airway inflammatory response to an acute bout of exercise in the postprandial period? Appl. Physiol. Nutr. Metab. 2017, 42, 173-180. [CrossRef]

371. Eftekhari, P.; Hajizadeh, S.; Reza Raoufy, M.; Reza Masjedi, M.; Yang, M.; Hansbro, N.; Li, J.J.; Foster, P.S. Preventive effect of $\mathrm{N}$-acetylcysteine in a mouse model of steroid resistant acute exacerbation of asthma. EXCLI J. 2013, 12, 184-192.

372. NCT02605824 Clinical Trial of NAC in Asthma-Full Text View-ClinicalTrials.gov. 2019. Available online: https://clinicaltrials.gov/show/NCT02605824 (accessed on 2 May 2020). 
373. Sakoda, C.P.P.; de Toledo, A.C.; Perini, A.; Pinheiro, N.M.; Hiyane, M.I.; dos Grecco, S.S.; de Fátima Lopes Calvo Tibério, I.; Câmara, N.O.S.; de Arruda Martins, M.; Lago, J.H.G.; et al. Sakuranetin reverses vascular peribronchial and lung parenchyma remodeling in a murine model of chronic allergic pulmonary inflammation. Acta Histochem. 2016, 118, 615-624. [CrossRef]

374. Toledo, A.C.; Sakoda, C.P.P.; Perini, A.; Pinheiro, N.M.; Magalhães, R.M.; Grecco, S.; Tibério, I.F.L.C.; Câmara, N.O.; Martins, M.A.; Lago, J.H.G.; et al. Flavonone treatment reverses airway inflammation and remodelling in an asthma murine model. Br. J. Pharmacol. 2013, 168, 1736-1749. [CrossRef]

375. Cho, I.H.; Choi, Y.J.; Gong, J.H.; Shin, D.; Kang, M.K.; Kang, Y.H. Astragalin inhibits autophagy-associated airway epithelial fibrosis. Respir. Res. 2015, 16, 51. [CrossRef]

376. Cho, I.H.; Gong, J.H.; Kang, M.K.; Lee, E.J.; Park, J.H.Y.; Park, S.J.; Kang, Y.H. Astragalin inhibits airway eotaxin-1 induction and epithelial apoptosis through modulating oxidative stress-responsive MAPK signaling. BMC Pulm. Med. 2014, 14, 122. [CrossRef] [PubMed]

377. André, D.M.; Calixto, M.C.; Sollon, C.; Alexandre, E.C.; Leiria, L.O.; Tobar, N.; Anhê, G.F.; Antunes, E. Therapy with resveratrol attenuates obesity-associated allergic airway inflammation in mice. Int. Immunopharmacol. 2016, 38, 298-305. [CrossRef] [PubMed]

378. André, D.M.; Calixto, M.C.; Sollon, C.; Alexandre, E.C.; Tavares, E.B.G.; Naime, A.C.A.; Anhê, G.F.; Antunes, E. High-fat diet-induced obesity impairs insulin signaling in lungs of allergen-challenged mice: Improvement by resveratrol. Sci. Rep. 2017, 7, 17296. [CrossRef] [PubMed]

379. Kandhare, A.D.; Liu, Z.; Mukherjee, A.A.; Bodhankar, S.L. Therapeutic Potential of Morin in Ovalbumin-induced Allergic Asthma Via Modulation of SUMF2/IL-13 and BLT2/NF-kB Signaling Pathway. Curr. Mol. Pharmacol. 2019, 12, 122-138. [CrossRef]

380. Bokhari, J.; Khan, M.R. Evaluation of anti-asthmatic and antioxidant potential of Boerhavia procumbens in toluene diisocyanate (TDI) treated rats. J. Ethnopharmacol. 2015, 172, 377-385. [CrossRef]

381. Wang, L.; Xu, M.L.; Liu, J.; Wang, Y.; Hu, J.H.; Wang, M.H. Sonchus asper extract inhibits LPS-induced oxidative stress and pro-inflammatory cytokine production in RAW264.7 macrophages. Nutr. Res. Pract. 2015, 9, 579-585. [CrossRef]

382. Ci, X.; Zhong, W.; Ren, H.; Wen, Z.; Li, D.; Peng, L. Esculentoside a attenuates allergic airway inflammation via activation of the Nrf-2 pathway. Int. Arch. Allergy Immunol. 2015, 167, 280-290. [CrossRef]

383. Jang, H.Y.; Kim, S.M.; Yuk, J.E.; Kwon, O.K.; Oh, S.R.; Lee, H.K.; Jeong, H.; Ahn, K.S. Capsicum annuum L. methanolic extract inhibits ovalbumin-induced airway inflammation and oxidative stress in a mouse model of asthma. J. Med. Food 2011, 14, 1144-1151. [CrossRef]

384. Sahreen, S.; Khan, M.R.; Khan, R.A.; Alkreathy, H.M. Cardioprotective role of leaves extracts of Carissa opaca against $\mathrm{CCl} 4$ induced toxicity in rats. BMC Res. Notes 2014, 7, 224. [CrossRef]

385. Bouch, S.; Harding, R.; O'Reilly, M.; Wood, L.G.; Sozo, F. Impact of dietary tomato juice on changes in pulmonary oxidative stress, inflammation and structure induced by neonatal hyperoxia in mice (Mus musculus). PLoS ONE 2016, 11, e0159633. [CrossRef]

386. Pigati, P.A.; Righetti, R.F.; Possa, S.S.; Romanholo, B.S.; Rodrigues, A.P.D.; dos Santos, A.S.A.; Xisto, D.G.; Antunes, M.A.; Prado, C.M.; Leick, E.A.; et al. Y-27632 is associated with corticosteroid-potentiated control of pulmonary remodeling and inflammation in guinea pigs with chronic allergic inflammation. BMC Pulm. Med. 2015, 15, 85. [CrossRef] [PubMed]

387. Righetti, R.F.; da Pigati, P.A.S.; Possa, S.S.; Habrum, F.C.; Xisto, D.G.; Antunes, M.A.; Leick, E.A.; Prado, C.M.; de Martins, M.A.; Rocco, P.R.M.; et al. Effects of Rho-kinase inhibition in lung tissue with chronic inflammation. Respir. Physiol. Neurobiol. 2014, 192, 134-146. [CrossRef] [PubMed]

388. Aristoteles, L.R.C.R.B.; Righetti, R.F.; Pinheiro, N.M.; Franco, R.B.; Starling, C.M.; da Silva, J.C.P.; Pigati, P.A.; Caperuto, L.C.; Prado, C.M.; Dolhnikoff, M.; et al. Modulation of the oscillatory mechanics of lung tissue and the oxidative stress response induced by arginase inhibition in a chronic allergic inflammation model. BMC Pulm. Med. 2013, 13, 1-13. [CrossRef] [PubMed]

389. Campos, D.; Ravagnani, F.G.; Gurgueira, S.A.; Vercesi, A.E.; Teixeira, S.A.; Costa, S.K.P.; Muscará, M.N.; Ferreira, H.H.A. Increased glutathione levels contribute to the beneficial effects of hydrogen sulfide and inducible nitric oxide inhibition in allergic lung inflammation. Int. Immunopharmacol. 2016, 39, 57-62. [CrossRef] [PubMed] 
390. Lucarini, L.; Pini, A.; Gerace, E.; Pellicciari, R.; Masini, E.; Moroni, F. Poly(ADP-ribose) polymerase inhibition with HYDAMTIQ reduces allergen-induced asthma-like reaction, bronchial hyper-reactivity and airway remodelling. J. Cell. Mol. Med. 2014, 18, 468-479. [CrossRef]

391. Dhawale, V.S.; Amara, V.R.; Karpe, P.A.; Malek, V.; Patel, D.; Tikoo, K. Activation of angiotensin-converting enzyme 2 (ACE2) attenuates allergic airway inflammation in rat asthma model. Toxicol. Appl. Pharmacol. 2016, 306, 17-26. [CrossRef]

392. Ho, C.Y.; Lu, C.C.; Weng, C.J.; Yen, G.C. Protective Effects of Diallyl Sulfide on Ovalbumin-Induced Pulmonary Inflammation of Allergic Asthma Mice by MicroRNA-144, -34a, and -34b/c-Modulated Nrf2 Activation. J. Agric. Food Chem. 2016, 64, 151-160. [CrossRef]

393. Yoon, S.Y.; Hong, G.H.; Kwon, H.S.; Park, S.; Park, S.Y.; Shin, B.; Kim, T.B.; Moon, H.B.; Cho, Y.S. S-adenosylmethionine reduces airway inflammation and fibrosis in a murine model of chronic severe asthma via suppression of oxidative stress. Exp. Mol. Med. 2016, 48, e236. [CrossRef]

394. Tlili, M.; Rouatbi, S.; Sriha, B.; Ben Rhouma, K.; Sakly, M.; Vaudry, D.; Wurtz, O.; Tebourbi, O. Pituitary Adenylate Cyclase-Activating Polypeptide Reverses Ammonium Metavanadate-Induced Airway Hyperresponsiveness in Rats. Oxid. Med. Cell. Longev. 2015, 2015, 787561. [CrossRef]

395. Gong, J.H.; Shin, D.; Han, S.Y.; Park, S.H.; Kang, M.K.; Kim, J.L.; Kang, Y.H. Blockade of airway inflammation by kaempferol via disturbing Tyk-STAT signaling in airway epithelial cells and in asthmatic mice. Evid. Based Complement. Altern. Med. 2013, 2013, 250725. [CrossRef]

396. Liu, H.; Xue, J.X.; Li, X.; Ao, R.; Lu, Y. Quercetin liposomes protect against radiation-induced pulmonary injury in a murine model. Oncol. Lett. 2013, 6, 453-459. [CrossRef] [PubMed]

397. Huang, R.; Zhong, T.; Wu, H. Quercetin protects against lipopolysaccharide-induced acute lung injury in rats through suppression of inflammation and oxidative stress. Arch. Med. Sci. 2015, 11, 427-432. [CrossRef] [PubMed]

398. Yasui, M.; Matsushima, M.; Omura, A.; Mori, K.; Ogasawara, N.; Kodera, Y.; Shiga, M.; Ito, K.; Kojima, S.; Kawabe, T. The Suppressive Effect of Quercetin on Toll-Like Receptor 7-Mediated Activation in Alveolar Macrophages. Pharmacology 2015, 96, 201-209. [CrossRef] [PubMed]

399. Zhang, M.; Lin, J.M.; Li, X.S.; Li, J. Quercetin ameliorates LPS-induced inflammation in human peripheral blood mononuclear cells by inhibition of the TLR2-NF-KB pathway. Genet. Mol. Res. 2016, 15, 15028297. [CrossRef]

400. Takeda, K.; Miyahara, N.; Matsubara, S.; Taube, C.; Kitamura, K.; Hirano, A.; Tanimoto, M.; Gelfand, E.W. Immunomodulatory effects of ambroxol on airway hyperresponsiveness and inflammation. Immune Netw. 2016, 16, 165-175. [CrossRef]

401. Raju, K.R.S.; Kumar, M.N.S.; Gupta, S.; Naga, S.T.; Shankar, J.K.; Murthy, V.; Madhunapanthula, S.R.V.; Mulukutla, S.; Ambhore, N.S.; Tummala, S.; et al. 5-Aminosalicylic Acid attenuates allergen-induced airway inflammation and oxidative stress in asthma. Pulm. Pharmacol. Ther. 2014, 29, 209-216. [CrossRef]

402. Nader, M.A. Inhibition of airway inflammation and remodeling by sitagliptin in murine chronic asthma. Int. Immunopharmacol. 2015, 29, 761-769. [CrossRef]

403. Abdel-Fattah, M.M.; Messiha, B.A.S.; Salama, A.A.A. Assessment of the Mechanistic Role of Cinnarizine in Modulating Experimentally-Induced Bronchial Asthma in Rats. Pharmacology 2015, 96, 167-174. [CrossRef]

404. Pavord, I.D.; Chanez, P.; Criner, G.J.; Kerstjens, H.A.M.; Korn, S.; Lugogo, N.; Martinot, J.B.; Sagara, H.; Albers, F.C.; Bradford, E.S.; et al. Mepolizumab for eosinophilic chronic obstructive pulmonary disease. N. Engl. J. Med. 2017, 377, 1613-1629. [CrossRef]

405. Fernandez Romero, G.A.; Beros, J.; Criner, G. Mepolizumab for the prevention of chronic obstructive pulmonary disease exacerbations. Expert Rev. Respir. Med. 2019, 13, 125-132. [CrossRef]

406. Criner, G.J.; Celli, B.R.; Brightling, C.E.; Agusti, A.; Papi, A.; Singh, D.; Sin, D.D.; Vogelmeier, C.F.; Sciurba, F.C.; Bafadhel, M.; et al. Benralizumab for the prevention of COPD exacerbations. N. Engl. J. Med. 2019, 381, 1023-1034. [CrossRef] [PubMed]

407. Brightling, C.E.; Bleecker, E.R.; Panettieri, R.A.; Bafadhel, M.; She, D.; Ward, C.K.; Xu, X.; Birrell, C.; van der Merwe, R. Benralizumab for chronic obstructive pulmonary disease and sputum eosinophilia: A randomised, double-blind, placebo-controlled, phase 2a study. Lancet Respir. Med. 2014, 2, 891-901. [CrossRef]

408. NCT02138916 Benralizumab Efficacy in Moderate to Very Severe Chronic Obstructive Pulmonary Disease (COPD) With Exacerbation History-Full Text View—ClinicalTrials.gov. 2019. Available online: https: //clinicaltrials.gov/show/NCT02138916 (accessed on 2 May 2020). 
409. Barnes, P.J. New anti-inflammatory targets for chronic obstructive pulmonary disease. Nat. Rev. Drug Discov. 2013, 12, 543-559. [CrossRef] [PubMed]

410. Global Initiative for Chronic Obstructive Lung Disease: Pocket Guide To COPD Diagnosis, Management, and Prevention, A Guide for Health Care Professionals. 2017 Report. Available online: https://goldcopd.org /wp-content/uploads/2016/12/wms-GOLD-2017-Pocket-Guide.pdf (accessed on 25 September 2020).

411. Yang, I.A.; Clarke, M.S.; Sim, E.H.; Fong, K.M. Inhaled corticosteroids for stable chronic obstructive pulmonary disease. Cochrane Database Syst. Rev. 2012, 2012, CD002991. [CrossRef]

412. Nannini, L.J.; Poole, P.; Milan, S.J.; Holmes, R.; Normansell, R. Combined corticosteroid and long-acting beta2-agonist in one inhaler versus placebo for chronic obstructive pulmonary disease. Cochrane Database Syst. Rev. 2013, 2017, CD003794. [CrossRef]

413. Calzetta, L.; Di Marco, F.; Blasi, F.; Cazzola, M.; Centanni, S.; Micheletto, C.; Rossi, A.; Rogliani, P. Impact of ICS/LABA and LABA/LAMA FDCs on functional and clinical outcomes in COPD: A network meta-analysis. Pulm. Pharmacol. Ther. 2019, 59, 101855. [CrossRef]

414. Barnes, P.J. Corticosteroid resistance in patients with asthma and chronic obstructive pulmonary disease. J. Allergy Clin. Immunol. 2013, 131, 636-645. [CrossRef]

415. Rennard, S.I.; Dale, D.C.; Donohue, J.F.; Kanniess, F.; Magnussen, H.; Sutherland, E.R.; Watz, H.; Lu, S.; Stryszak, P.; Rosenberg, E.; et al. CXCR2 antagonist MK-7123 a phase 2 proof-of-concept trial for chronic obstructive pulmonary disease. Am. J. Respir. Crit. Care Med. 2015, 191, 1001-1011. [CrossRef]

416. Barreiro, E.; Wang, X.; Tang, J. COPD: Preclinical models and emerging therapeutic targets. Expert Opin. Ther. Targets 2019, 23, 829-838. [CrossRef]

417. Paul, T.; Salazar-Degracia, A.; Peinado, V.I.; Tura-Ceide, O.; Blanco, I.; Barreiro, E.; Barberà, J.A. Soluble guanylate cyclase stimulation reduces oxidative stress in experimental Chronic Obstructive Pulmonary Disease. PLoS ONE 2018, 13, e0190628. [CrossRef]

418. Barreiro, E.; Puig-Vilanova, E.; Marin-Corral, J.; Chacón-Cabrera, A.; Salazar-Degracia, A.; Mateu, X.; Puente-Maestu, L.; García-Arumí, E.; Andreu, A.L.; Molina, L. Therapeutic Approaches in Mitochondrial Dysfunction, Proteolysis, and Structural Alterations of Diaphragm and Gastrocnemius in Rats With Chronic Heart Failure. J. Cell. Physiol. 2016, 231, 1495-1513. [CrossRef]

419. Brasier, A.R. Therapeutic targets for inflammation-mediated airway remodeling in chronic lung disease. Expert Rev. Respir. Med. 2018, 12, 931-939. [CrossRef] [PubMed]

420. Liu, Z.; Tian, B.; Chen, H.; Wang, P.; Brasier, A.R.; Zhou, J. Discovery of potent and selective BRD4 inhibitors capable of blocking TLR3-induced acute airway inflammation. Eur. J. Med. Chem. 2018, 151, 450-461. [CrossRef]

421. Liu, Z.; Wang, P.; Chen, H.; Wold, E.A.; Tian, B.; Brasier, A.R.; Zhou, J. Drug Discovery Targeting Bromodomain-Containing Protein 4. J. Med. Chem. 2017, 60, 4533-4558. [CrossRef] [PubMed]

422. Broekman, W.; Khedoe, P.P.S.J.; Schepers, K.; Roelofs, H.; Stolk, J.; Hiemstra, P.S. Mesenchymal stromal cells: A novel therapy for the treatment of chronic obstructive pulmonary disease? Thorax 2018, 73, 565-574. [CrossRef] [PubMed]

423. Raghu, G. Pharmacotherapy for idiopathic pulmonary fibrosis: Current landscape and future potential. Eur. Respir. Rev. 2017, 26, 170071. [CrossRef] [PubMed]

424. Margaritopoulos, G.A.; Trachalaki, A.; Wells, A.U.; Vasarmidi, E.; Bibaki, E.; Papastratigakis, G.; Detorakis, S.; Tzanakis, N.; Antoniou, K.M. Pirfenidone improves survival in IPF: Results from a real-life study. BMC Pulm. Med. 2018, 18, 177. [CrossRef]

425. Somogyi, V.; Chaudhuri, N.; Torrisi, S.E.; Kahn, N.; Müller, V.; Kreuter, M. The therapy of idiopathic pulmonary fibrosis: What is next? Eur. Respir. Rev. 2019, 28, 190021. [CrossRef]

426. Lederer, D.J.; Martinez, F.J. Idiopathic Pulmonary Fibrosis. N. Engl. J. Med. 2018, 378, 1811-1823. [CrossRef]

427. Murray, L.A.; Rosada, R.; Moreira, A.P.; Joshi, A.; Kramer, M.S.; Hesson, D.P.; Argentieri, R.L.; Mathai, S.; Gulati, M.; Herzog, E.L.; et al. Serum amyloid P therapeutically attenuates murine bleomycin-induced pulmonary fibrosis via its effects on macrophages. PLoS ONE 2010, 5, e9683. [CrossRef]

428. Santhiago, M.R.; Singh, V.; Barbosa, F.L.; Agrawal, V.; Wilson, S.E. Monocyte development inhibitor PRM-151 decreases corneal myofibroblast generation in rabbits. Exp. Eye Res. 2011, 93, 786-789. [CrossRef] [PubMed] 
429. Van Den Blink, B.; Dillingh, M.R.; Ginns, L.C.; Morrison, L.D.; Moerland, M.; Wijsenbeek, M.; Trehu, E.G.; Bartholmai, B.J.; Burggraaf, J. Recombinant human pentraxin-2 therapy in patients with idiopathic pulmonary fibrosis: Safety, pharmacokinetics and exploratory efficacy. Eur. Respir. J. 2016, 47, 889-897. [CrossRef] [PubMed]

430. Raghu, G.; Van Den Blink, B.; Hamblin, M.J.; Whitney Brown, A.; Golden, J.A.; Ho, L.A.; Wijsenbeek, M.S.; Vasakova, M.; Pesci, A.; Antin-Ozerkis, D.E.; et al. Effect of recombinant human pentraxin 2 vs placebo on change in forced vital capacity in patients with idiopathic pulmonary fibrosis a randomized clinical trial. JAMA J. Am. Med. Assoc. 2018, 319, 2299-2307. [CrossRef] [PubMed]

431. Raghu, G.; van den Blink, B.; Hamblin, M.J.; Brown, A.W.; Golden, J.A.; Ho, L.A.; Wijsenbeek, M.S.; Vasakova, M.; Pesci, A.; Antin-Ozerkis, D.E.; et al. Long-term treatment with recombinant human pentraxin 2 protein in patients with idiopathic pulmonary fibrosis: An open-label extension study. Lancet Respir. Med. 2019, 7, 657-664. [CrossRef]

432. NCT01890265 Evaluate the Safety and Efficacy of FG-3019 (Pamrevlumab) in Participants With Idiopathic Pulmonary Fibrosis (IPF)—Full Text View_ClinicalTrials.gov. 2020. Available online: https://clinicaltrials.g ov/show/NCT01890265 (accessed on 20 September 2020).

433. Gorina, E.; Richeldi, L.; Raghu, G.; Fernandez Perez, E.; Costabel, U.; Albera, C.; Lederer, D.; Flaherty, K.; Ettinger, N.; Bercz, P.; et al. PRAISE, a randomized, placebo-controlled, double-blind Phase 2 clinical trial of pamrevlumab (FG-3019) in IPF patients. Eur. Respir. J. 2017, 50, OA3400.

434. Gagnon, L.; Leduc, M.; Thibodeau, J.F.; Zhang, M.Z.; Grouix, B.; Sarra-Bournet, F.; Gagnon, W.; Hince, K.; Tremblay, M.; Geerts, L.; et al. A Newly Discovered Antifibrotic Pathway Regulated by Two Fatty Acid Receptors: GPR40 and GPR84. Am. J. Pathol. 2018, 188, 1132-1148. [CrossRef]

435. Khalil, N.; Manganas, H.; Ryerson, C.J.; Shapera, S.; Cantin, A.M.; Hernandez, P.; Turcotte, E.E.; Parker, J.M.; Moran, J.E.; Albert, G.R.; et al. Phase 2 clinical trial of PBI-4050 in patients with idiopathic pulmonary fibrosis. Eur. Respir. J. 2019, 53, 1800663. [CrossRef]

436. NCT02738801 Study to Assess Safety, Tolerability, Pharmacokinetic and Pharmacodynamic Properties of GLPG1690. 2017. Available online: https:/clinicaltrials.gov/show/NCT02738801 (accessed on 20 September 2020).

437. Maher, T.M.; van der Aar, E.M.; Van de Steen, O.; Allamassey, L.; Desrivot, J.; Dupont, S.; Fagard, L.; Ford, P.; Fieuw, A.; Wuyts, W. Safety, tolerability, pharmacokinetics, and pharmacodynamics of GLPG1690, a novel autotaxin inhibitor, to treat idiopathic pulmonary fibrosis (FLORA): A phase 2a randomised placebo-controlled trial. Lancet Respir. Med. 2018, 6, 627-635. [CrossRef]

438. Maher, T.M.; Kreuter, M.; Lederer, D.J.; Brown, K.K.; Wuyts, W.; Verbruggen, N.; Stutvoet, S.; Fieuw, A.; Ford, P.; Abi-Saab, W.; et al. Rationale, design and objectives of two phase III, randomised, placebo-controlled studies of GLPG1690, a novel autotaxin inhibitor, in idiopathic pulmonary fibrosis (ISABELA 1 and 2). BMJ Open Respir. Res. 2019, 6, e000422. [CrossRef]

439. Peters-Golden, M.; Henderson, W.R. University of Michigan Health Sys-tem, 6301 MSRB III, 1150 W. Medical Cen-ter Dr. N. Engl. J. Med. 2007, 357, 1841-1854. [CrossRef]

440. Izumo, T.; Kondo, M.; Nagai, A. Effects of a leukotriene B4 receptor antagonist on bleomycin-induced pulmonary fibrosis. Eur. Respir. J. 2009, 34, 1444-1451. [CrossRef] [PubMed]

441. NCT02503657 Safety and Tolerability Study in Subjects With Idiopathic Pulmonary Fibrosis (IPF)—Full Text View-ClinicalTrials.gov. 2020. Available online: https://clinicaltrials.gov/show/NCT02503657 (accessed on 20 September 2020).

442. NCT02688647 A Study to Evaluate the Safety, Tolerability, and Activity of KD025 in Subjects With Idiopathic Pulmonary Fibrosis. 2019. Available online: https://linicaltrials.gov/show/NCT02688647 (accessed on 20 September 2020).

443. Zanin-Zhorov, A.; Weiss, J.M.; Nyuydzefe, M.S.; Chen, W.; Scher, J.U.; Mo, R.; Depoil, D.; Rao, N.; Liu, B.; Wei, J.; et al. Selective oral ROCK2 inhibitor down-regulates IL-21 and IL-17 secretion in human T cells via STAT3-dependent mechanism. Proc. Natl. Acad. Sci. USA 2014, 111, 16814-16819. [CrossRef] [PubMed]

444. NCT03142191 A Study to Evaluate the Efficacy and Safety of CC-90001 in Subjects With Idiopathic Pulmonary Fibrosis-Full Text View-ClinicalTrials.gov. 2020. Available online: https://clinicaltrials.gov/show/NCT031 42191 (accessed on 20 September 2020).

445. van der Velden, J.L.J.; Ye, Y.; Nolin, J.D.; Hoffman, S.M.; Chapman, D.G.; Lahue, K.G.; Abdalla, S.; Chen, P.; Liu, Y.; Bennett, B.; et al. JNK inhibition reduces lung remodeling and pulmonary fibrotic systemic markers. Clin. Transl. Med. 2016, 5, 36. [CrossRef] [PubMed] 
446. Horan, G.S.; Wood, S.; Ona, V.; Dan, J.L.; Lukashev, M.E.; Weinreb, P.H.; Simon, K.J.; Hahm, K.; Allaire, N.E.; Rinaldi, N.J.; et al. Partial inhibition of integrin $\alpha \mathrm{v} \beta 6$ prevents pulmonary fibrosis without exacerbating inflammation. Am. J. Respir. Crit. Care Med. 2008, 177, 56-65. [CrossRef] [PubMed]

447. NCT01371305 STX-100 in Patients With Idiopathic Pulmonary Fibrosis (IPF)—Full Text View-ClinicalTrials.gov. 2020. Available online: https://clinicaltrials.gov/show/NCT01371305 (accessed on 20 September 2020).

448. Zhang, X.L.; Xing, R.G.; Chen, L.; Liu, C.R.; Miao, Z.G. PI3K/Akt signaling is involved in the pathogenesis of bleomycin-induced pulmonary fibrosis via regulation of epithelial-mesenchymal transition. Mol. Med. Rep. 2016, 14, 5699-5706. [CrossRef] [PubMed]

449. NCT01725139 A Proof of Mechanism Study With GSK2126458 in Patients With Idiopathic Pulmonary Fibrosis (IPF)—Full Text View—ClinicalTrials.gov. 2019. Available online: https://clinicaltrials.gov/show/NCT01725 139 (accessed on 20 September 2020).

450. Mercer, P.F.; Woodcock, H.V.; Eley, J.D.; Platé, M.; Sulikowski, M.G.; Durrenberger, P.F.; Franklin, L.; Nanthakumar, C.B.; Man, Y.; Genovese, F.; et al. Exploration of a potent PI3 kinase/mTOR inhibitor as a novel anti-fibrotic agent in IPF. Thorax 2016, 71, 701-711. [CrossRef]

451. Lukey, P.T.; Harrison, S.A.; Yang, S.; Man, Y.; Holman, B.F.; Rashidnasab, A.; Azzopardi, G.; Grayer, M.; Simpson, J.K.; Bareille, P.; et al. A randomised, placebo-controlled study of omipalisib (PI3K/mTOR) in idiopathic pulmonary fibrosis. Eur. Respir. J. 2019, 53, 1801992. [CrossRef]

452. NCT01462006 Double-blind Placebo-controlled Pilot Study of Sirolimus in Idiopathic Pulmonary Fibrosis (IPF). 2018. Available online: https://clinicaltrials.gov/show/NCT01462006 (accessed on 20 September 2020).

453. NCT01969409 Autoantibody Reduction Therapy in Patients With Idiopathic Pulmonary Fibrosis. 2020. Available online: https://clinicaltrials.gov/show/NCT01969409 (accessed on 20 September 2020).

454. NCT01266317 Combined PEX, Rituximab and Steroids in Acute Idiopathic Pulmonary Fibrosis Exacerbations—Full Text View—ClinicalTrials.gov. 2018. Available online: https://clinicaltrials.gov/show/NC T01266317 (accessed on 20 September 2020).

455. Donahoe, M.; Valentine, V.G.; Chien, N.; Gibson, K.F.; Raval, J.S.; Saul, M.; Xue, J.; Zhang, Y.; Duncan, S.R. Autoantibody-targeted treatments for acute exacerbations of idiopathic pulmonary fibrosis. PLoS ONE 2015, 10, e0127771.

456. NCT01777737 Study to Test the Validity of the Treatment of Idiopathic Pulmonary Fibrosis With Cotrimoxazole. 2017. Available online: https://clinicaltrials.gov/show/nct01777737 (accessed on 20 September 2020).

457. NCT01872689 A Study of Lebrikizumab in Patients With Idiopathic Pulmonary Fibrosis-Full Text View-ClinicalTrials.gov. 2018; pp. 5-7. Available online: https://clinicaltrials.gov/show/NCT01872689 (accessed on 20 September 2020).

458. NCT01629667 A Phase 2, Randomized Dose-ranging Study to Evaluate the Efficacy of Tralokinumab in Adults With Idiopathic Pulmonary Fibrosis-Full Text View-ClinicalTrials.gov. 2017. Available online: https://clinicaltrials.gov/show/NCT01629667 (accessed on 20 September 2020).

459. NCT02173145 Azithromycin in Idiopathic Pulmonary Fibrosis_Full Text View_ClinicalTrials.gov. 2019. Available online: https://clinicaltrials.gov/show/NCT02173145 (accessed on 20 September 2020).

460. Cazzola, M.; Matera, M.G.; Rogliani, P.; Calzetta, L. Senolytic drugs in respiratory medicine: Is it an appropriate therapeutic approach? Expert Opin. Investig. Drugs 2018, 27, 573-581. [CrossRef]

461. Malayeri, A.R.; Hemmati, A.A.; Arzi, A.; Rezaie, A.; Ghafurian-Boroojerdnia, M.; Khalili, H.R. A comparison of the effects of quercetin hydrate with those of vitamin E on the levels of IL-13, PDGF, TNF- $\alpha$, and INF- $\gamma$ in bleomycin-induced pulmonary fibrosis in rats. Jundishapur J. Nat. Pharm. Prod. 2016, 11. [CrossRef]

462. Schafer, M.J.; White, T.A.; Iijima, K.; Haak, A.J.; Ligresti, G.; Atkinson, E.J.; Oberg, A.L.; Birch, J.; Salmonowicz, H.; Zhu, Y.; et al. Cellular senescence mediates fibrotic pulmonary disease. Nat. Commun. 2017, 8, 14532. [CrossRef]

463. Lehmann, M.; Korfei, M.; Mutze, K.; Klee, S.; Skronska-Wasek, W.; Alsafadi, H.N.; Ota, C.; Costa, R.; Schiller, H.B.; Lindner, M.; et al. Senolytic drugs target alveolar epithelial cell function and attenuate experimental lung fibrosis ex vivo. Eur. Respir. J. 2017, 50, 1602367. [CrossRef] [PubMed]

464. Barkauskas, C.E.; Cronce, M.J.; Rackley, C.R.; Bowie, E.J.; Keene, D.R.; Stripp, B.R.; Randell, S.H.; Noble, P.W.; Hogan, B.L.M. Type 2 alveolar cells are stem cells in adult lung. J. Clin. Investig. 2013, 123, 3025-3036. [CrossRef] [PubMed] 
465. Sisson, T.H.; Mendez, M.; Choi, K.; Subbotina, N.; Courey, A.; Cunningham, A.; Dave, A.; Engelhardt, J.F.; Liu, X.; White, E.S.; et al. Targeted injury of type II alveolar epithelial cells induces pulmonary fibrosis. Am. J. Respir. Crit. Care Med. 2010, 181, 254-263. [CrossRef] [PubMed]

466. Martyanov, V.; Kim, G.H.J.; Hayes, W.; Du, S.; Ganguly, B.J.; Sy, O.; Lee, S.K.; Bogatkevich, G.S.; Schieven, G.L.; Schiopu, E.; et al. Novel lung imaging biomarkers and skin gene expression subsetting in dasatinib treatment of systemic sclerosis-associated interstitial lung disease. PLoS ONE 2017, 12, e0187580. [CrossRef] [PubMed]

467. Guignabert, C.; Phan, C.; Seferian, A.; Huertas, A.; Tu, L.; Thuillet, R.; Sattler, C.; Le Hiress, M.; Tamura, Y.; Jutant, E.M.; et al. Dasatinib induces lung vascular toxicity and predisposes to pulmonary hypertension. J. Clin. Investig. 2016, 126, 3207-3218. [CrossRef]

468. Mailleux, A.A.; Crestani, B. Licence to kill senescent cells in idiopathic pulmonary fibrosis? Eur. Respir. J. 2017, 50, 1701360. [CrossRef]

469. Banerjee, E.R.; Kar, S.; Konsam, S.; Hore, G.; Mitra, S.; Biswas, S.; Sinha, A.; Jana, N.R. Therapeutic use of fisetin, curcumin, and mesoporous carbon nanoparticle loaded fisetin in bleomycin-induced idiopathic pulmonary fibrosis. Biomed. Res. Ther. 2015, 2, 250-262. [CrossRef]

470. Pan, J.; Li, D.; Xu, Y.; Zhang, J.; Wang, Y.; Chen, M.; Lin, S.; Huang, L.; Chung, E.J.; Citrin, D.E.; et al. Inhibition of Bcl-2/xl With ABT-263 Selectively Kills Senescent Type II Pneumocytes and Reverses Persistent Pulmonary Fibrosis Induced by Ionizing Radiation in Mice. Int. J. Radiat. Oncol. Biol. Phys. 2017, 99, 353-361. [CrossRef]

471. Justice, J.N.; Nambiar, A.M.; Tchkonia, T.; LeBrasseur, N.K.; Pascual, R.; Hashmi, S.K.; Prata, L.; Masternak, M.M.; Kritchevsky, S.B.; Musi, N.; et al. Senolytics in idiopathic pulmonary fibrosis: Results from a first-in-human, open-label, pilot study. EBioMedicine 2019, 40, 554-563. [CrossRef]

472. Habib, A.R.R.; Kajbafzadeh, M.; Desai, S.; Yang, C.L.; Skolnik, K.; Quon, B.S. A Systematic Review of the Clinical Efficacy and Safety of CFTR Modulators in Cystic Fibrosis. Sci. Rep. 2019, 9, 7234. [CrossRef] [PubMed]

473. Clancy, J.P.; Cotton, C.U.; Donaldson, S.H.; Solomon, G.M.; VanDevanter, D.R.; Boyle, M.P.; Gentzsch, M.; Nick, J.A.; Illek, B.; Wallenburg, J.C.; et al. CFTR modulator theratyping: Current status, gaps and future directions. J. Cyst. Fibros. 2019, 18, 22-34. [CrossRef] [PubMed]

474. Lopes-Pacheco, M. CFTR Modulators: The Changing Face of Cystic Fibrosis in the Era of Precision Medicine. Front. Pharmacol. 2020, 10, 1662. [CrossRef] [PubMed]

475. Lopes-Pacheco, M. CFTR modulators: Shedding light on precision medicine for cystic fibrosis. Front. Pharmacol. 2016, 7, 275. [CrossRef]

476. Li, H.; Pesce, E.; Sheppard, D.N.; Singh, A.K.; Pedemonte, N. Therapeutic approaches to CFTR dysfunction: From discovery to drug development. J. Cyst. Fibros. 2018, 17, S14-S21. [CrossRef]

477. Van Goor, F.; Hadida, S.; Grootenhuis, P.D.J.; Burton, B.; Stack, J.H.; Straley, K.S.; Decker, C.J.; Miller, M.; McCartney, J.; Olson, E.R.; et al. Correction of the F508del-CFTR protein processing defect in vitro by the investigational drug VX-809. Proc. Natl. Acad. Sci. USA 2011, 108, 18843-18848. [CrossRef]

478. Ratjen, F.; Hug, C.; Marigowda, G.; Tian, S.; Huang, X.; Stanojevic, S.; Milla, C.E.; Robinson, P.D.; Waltz, D.; Davies, J.C.; et al. Efficacy and safety of lumacaftor and ivacaftor in patients aged 6-11 years with cystic fibrosis homozygous for F508del-CFTR: A randomised, placebo-controlled phase 3 trial. Lancet Respir. Med. 2017, 5, 557-567. [CrossRef]

479. Konstan, M.W.; McKone, E.F.; Moss, R.B.; Marigowda, G.; Tian, S.; Waltz, D.; Huang, X.; Lubarsky, B.; Rubin, J.; Millar, S.J.; et al. Assessment of safety and efficacy of long-term treatment with combination lumacaftor and ivacaftor therapy in patients with cystic fibrosis homozygous for the F508del-CFTR mutation (PROGRESS): A phase 3, extension study. Lancet Respir. Med. 2017, 5, 107-118. [CrossRef]

480. Wainwright, C.E.; Elborn, J.S.; Ramsey, B.W.; Marigowda, G.; Huang, X.; Cipolli, M.; Colombo, C.; Davies, J.C.; De Boeck, K.; Flume, P.A.; et al. Lumacaftor-ivacaftor in patients with cystic fibrosis homozygous for phe508del CFTR. N. Engl. J. Med. 2015, 373, 220-231. [CrossRef]

481. McElvaney, O.J.; Gunaratnam, C.; McElvaney, O.F.; Bagwe, I.; Reeves, E.P.; McElvaney, N.G. Emerging pharmacotherapies in cystic fibrosis. Expert Rev. Respir. Med. 2018, 12, 843-855. [CrossRef]

482. Pedemonte, N.; Lukacs, G.L.; Du, K.; Caci, E.; Zegarra-Moran, O.; Galietta, L.J.V.; Verkman, A.S. Small-molecule correctors of defective $\triangle$ F508-CFTR cellular processing identified by high-throughput screening. J. Clin. Investig. 2005, 115, 2564-2571. [CrossRef] 
483. Phuan, P.W.; Veit, G.; Tan, J.A.; Finkbeiner, W.E.; Lukacs, G.L.; Verkman, A.S. Potentiators of defective DF508-CFTR gating that do not interfere with corrector action. Mol. Pharmacol. 2015, 88, 791-799. [CrossRef] [PubMed]

484. Liang, F.; Shang, H.; Jordan, N.J.; Wong, E.; Mercadante, D.; Saltz, J.; Mahiou, J.; Bihler, H.J.; Mense, M. High-Throughput Screening for Readthrough Modulators of CFTR PTC Mutations. SLAS Technol. 2017, 22, 315-324. [CrossRef]

485. Giuliano, K.A.; Wachi, S.; Drew, L.; Dukovski, D.; Green, O.; Bastos, C.; Cullen, M.D.; Hauck, S.; Tait, B.D.; Munoz, B.; et al. Use of a High-Throughput Phenotypic Screening Strategy to Identify Amplifiers, a Novel Pharmacological Class of Small Molecules That Exhibit Functional Synergy with Potentiators and Correctors. SLAS Discov. 2018, 23, 111-121. [CrossRef]

486. Van Der Plas, S.E.; Kelgtermans, H.; De Munck, T.; Martina, S.L.X.; Dropsit, S.; Quinton, E.; De Blieck, A.; Joannesse, C.; Tomaskovic, L.; Jans, M.; et al. Discovery of N-(3-Carbamoyl-5,5,7,7-tetramethyl-5,7-dihydro-4H-thieno[2,3-c]pyran-2-yl)-1H-pyrazole-5-carboxamide (GLPG1837), a Novel Potentiator Which Can Open Class III Mutant Cystic Fibrosis Transmembrane Conductance Regulator (CFTR) Channels to a High. J. Med. Chem. 2018, 61, 1425-1435. [CrossRef]

487. Veit, G.; Xu, H.; Dreano, E.; Avramescu, R.G.; Bagdany, M.; Beitel, L.K.; Roldan, A.; Hancock, M.A.; Lay, C.; Li, W.; et al. Structure-guided combination therapy to potently improve the function of mutant CFTRs. Nat. Med. 2018, 24, 1732-1742. [CrossRef]

488. Wang, X.; Liu, B.; Searle, X.; Yeung, C.; Bogdan, A.; Greszler, S.; Singh, A.; Fan, Y.; Swensen, A.M.; Vortherms, T.; et al. Discovery of 4-[(2R,4R)-4-(\{[1-(2,2-Difluoro-1,3-benzodioxol-5-yl)cyclopropyl]carbonyl\}amino)-7-(difluoromethoxy)-3,4 -dihydro-2H-chromen-2-yl]benzoic Acid (ABBV/GLPG-2222), a Potent Cystic Fibrosis Transmembrane Conductance Regulator (CFTR) Corrector for. J. Med. Chem. 2018, 61, 1436-1449. [CrossRef] [PubMed]

489. Berg, A.; Hallowell, S.; Tibbetts, M.; Beasley, C.; Brown-Phillips, T.; Healy, A.; Pustilnik, L.; Doyonnas, R.; Pregel, M. High-Throughput Surface Liquid Absorption and Secretion Assays to Identify F508del CFTR Correctors Using Patient Primary Airway Epithelial Cultures. SLAS Discov. 2019, 24, 724-737. [CrossRef] [PubMed]

490. De Wilde, G.; Gees, M.; Musch, S.; Verdonck, K.; Jans, M.; Wesse, A.S.; Singh, A.K.; Hwang, T.C.; Christophe, T.; Pizzonero, M.; et al. Identification of GLPG/ABBV-2737, a novel class of corrector, which exerts functional synergy with other CFTR modulators. Front. Pharmacol. 2019, 10, 514. [CrossRef] [PubMed]

491. Merkert, S.; Schubert, M.; Olmer, R.; Engels, L.; Radetzki, S.; Veltman, M.; Scholte, B.J.; Zöllner, J.; Pedemonte, N.; Galietta, L.J.V.; et al. High-Throughput Screening for Modulators of CFTR Activity Based on Genetically Engineered Cystic Fibrosis Disease-Specific iPSCs. Stem Cell Rep. 2019, 12, 1389-1403. [CrossRef]

492. Rafeeq, M.M.; Murad, H.A.S. Cystic fibrosis: Current therapeutic targets and future approaches. J. Transl. Med. 2017, 15, 84. [CrossRef]

493. Cheng, K.; Ashby, D.; Smyth, R.L. Oral steroids for long-term use in cystic fibrosis. Cochrane Database Syst. Rev. 2015, 2015, CD000407. [CrossRef]

494. Balfour-Lynn, I.M.; Welch, K.; Smith, S. Inhaled corticosteroids for cystic fibrosis. Cochrane Database Syst. Rev. 2019, 2019, CD001915. [CrossRef] [PubMed]

495. Ross, K.R.; Chmiel, J.F.; Konstan, M.W. The role of inhaled corticosteroids in the management of cystic fibrosis. Pediatr. Drugs 2009, 11, 101-113. [CrossRef] [PubMed]

496. Lands, L.C.; Stanojevic, S. Oral non-steroidal anti-inflammatory drug therapy for lung disease in cystic fibrosis. Cochrane Database Syst. Rev. 2019, 2019, CD001505. [CrossRef] [PubMed]

497. Konstan, M.W.; VanDevanter, D.R.; Sawicki, G.S.; Pasta, D.J.; Foreman, A.J.; Neiman, E.A.; Morgan, W.J. Association of high-dose ibuprofen use, lung function decline, and long-term survival in children with cystic fibrosis. Ann. Am. Thorac. Soc. 2018, 15, 485-493. [CrossRef] [PubMed]

498. Konstan, M.W.; Döring, G.; Heltshe, S.L.; Lands, L.C.; Hilliard, K.A.; Koker, P.; Bhattacharya, S.; Staab, A.; Hamilton, A. A randomized double blind, placebo controlled phase 2 trial of BIIL 284 BS (an LTB4 receptor antagonist) for the treatment of lung disease in children and adults with cystic fibrosis. J. Cyst. Fibros. 2014, 13, 148-155. [CrossRef]

499. Elborn, J.S.; Bhatt, L.; Grosswald, R.; Ahuja, S.; Springman, E.B. Phase I Studies of Acebilustat: Pharmacokinetics, Pharmacodynamics, Food Effect, and CYP3A Induction. Clin. Transl. Sci. 2017, 10, 20-27. [CrossRef] 
500. Elborn, J.S.; Ahuja, S.; Springman, E.; Mershon, J.; Grosswald, R.; Rowe, S.M. EMPIRE-CF: A phase II randomized placebo-controlled trial of once-daily, oral acebilustat in adult patients with cystic fibrosis-Study design and patient demographics. Contemp. Clin. Trials 2018, 72, 86-94. [CrossRef]

501. NCT02759562 Effect of Andecaliximab on FEV1 in Adults With Cystic Fibrosis-Full Text View-ClinicalTrials.gov. 2018. Available online: https://clinicaltrials.gov/show/NCT02759562 (accessed on 3 May 2020).

502. NCT03748199 Clinical Study to Investigate Safety, Tolerability, Pharmacokinetics and Pharmacodynamics of POL6014 in Patients with CF-Full Text View-ClinicalTrials.gov. 2018. Available online: https://clinicaltrials .gov/show/NCT03748199 (accessed on 3 May 2020).

503. McElvaney, N.G. Alpha-1 antitrypsin therapy in cystic fibrosis and the lung disease associated with alpha-1 antitrypsin deficiency. Ann. Am. Thorac. Soc. 2016, 13, S191-S196. [PubMed]

504. Elborn, J.S.; Perrett, J.; Forsman-Semb, K.; Marks-Konczalik, J.; Gunawardena, K.; Entwistle, N. Efficacy, safety and effect on biomarkers of AZD9668 in cystic fibrosis. Eur. Respir. J. 2012, 40, 969-976. [CrossRef] [PubMed]

505. Motwani, M.; Bennett, F.; Tepper, M.; White, B.; Norris, P.; MacAllister, R.; Serhan, C.; Gilroy, D. Anabasum (JBT-101) enhances resolution of inflammation in humans. Arthritis Rheumatol. 2017, 69 (Suppl. 10). Available online: https:/acrabstracts.org/abstract/anabasum-jbt-101-enhances-resolution-of-inflammationin-humans/ (accessed on 7 December 2020).

506. NCT02465450 Safety, Tolerability, Pharmacokinetics, and Efficacy of JBT-101 (Lenabasum) in Cystic Fibrosis-Full Text View-ClinicalTrials.gov. Available online: https://clinicaltrials.gov/ct2/show/NCT02465 450 (accessed on 20 September 2020).

507. Burstein, S.H. Ajulemic acid: Potential treatment for chronic inflammation. Pharmacol. Res. Perspect. 2018, 6, e00394. [CrossRef] [PubMed]

508. Pertwee, R.G. Endocannabinoids and their pharmacological actions. In Handbook of Experimental Pharmacology; Springer: New York, NY, USA, 2015; Volume 231, pp. 1-37.

509. Gkoumassi, E.; Dekkers, B.G.J.; Dröge, M.J.; Elzinga, C.R.S.; Schmidt, M.; Meurs, H.; Zaagsma, J.; Nelemans, S.A. Virodhamine and CP55,940 modulate cAMP production and IL-8 release in human bronchial epithelial cells. Br. J. Pharmacol. 2007, 151, 1041-1048. [CrossRef] [PubMed]

510. McElvaney, N.G.; Hubbard, R.C.; Birrer, P.; Crystal, R.G.; Chernick, M.S.; Frank, M.M.; Caplan, D.B. Aerosol $\alpha 1$ -antitrypsin treatment for cystic fibrosis. Lancet 1991, 337, 392-394. [CrossRef]

511. Griese, M.; Latzin, P.; Kappler, M.; Weckerle, K.; Heinzimaier, T.; Bernhardt, T.; Hartl, D. $\alpha 1$-Antitrypsin inhalation reduces airway inflammation in cystic fibrosis patients. Eur. Respir. J. 2007, 29, 240-250. [CrossRef]

512. Grimbert, D.; Vecellio, L.; Delépine, P.; Attucci, S.; Boissinot, E.; Poncin, A.; Gauthier, F.; Valat, C.; Saudubray, F.; Antonioz, P.; et al. Characteristics of EPI-hNE4 aerosol: A new elastase inhibitor for treatment of cystic fibrosis. J. Aerosol Med. Depos. Clear. Eff. Lung 2003, 16, 121-129. [CrossRef]

513. Williams, B.; Robinette, M.; Slovis, B.; Deretci, V.; Perkett, E. Hydroxychloroquine-Pilot study of anti-inflammatory effects in cystic fibrosis. Pediatr. Pulmonol. 2008, 43, 314.

514. Moss, R.B.; Mistry, S.J.; Konstan, M.W.; Pilewski, J.M.; Kerem, E.; Tal-Singer, R.; Lazaar, A.L. Safety and early treatment effects of the CXCR2 antagonist SB-656933 in patients with cystic fibrosis. J. Cyst. Fibros. 2013, 12, 241-248. [CrossRef]

515. Ballmann, M.; Junge, S.; von der Hardt, H. Low-dose methotrexate for advanced pulmonary disease in patients with cystic fibrosis. Respir. Med. 2003, 97, 498-500. [CrossRef]

516. McElvaney, O.J.; McElvaney, N.G. Targeting IL-8 in cystic fibrosis: Enough but not too much. Am. J. Respir. Cell Mol. Biol. 2018, 59, 401-402. [CrossRef] [PubMed]

517. McElvaney, O.J.; O’Reilly, N.; White, M.; Lacey, N.; Pohl, K.; Gerlza, T.; Bergin, D.A.; Kerr, H.; McCarthy, C.; O'Brien, M.E.; et al. The effect of the decoy molecule PA401 on CXCL8 levels in bronchoalveolar lavage fluid of patients with cystic fibrosis. Mol. Immunol. 2015, 63, 550-558. [CrossRef] [PubMed]

518. Karp, C.L.; Flick, L.M.; Park, K.W.; Softic, S.; Greer, T.M.; Keledjian, R.; Yang, R.; Uddin, J.; Guggino, W.B.; Atabani, S.F.; et al. Defective lipoxin-mediated anti-inflammatory activity in the cystic fibrosis airway. Nat. Immunol. 2004, 5, 388-392. [CrossRef] [PubMed]

519. József, L.; Zouki, C.; Petasis, N.A.; Serhan, C.N.; Filep, J.G. Lipoxin A4 and aspirin-triggered 15-epi-lipoxin A4 inhibit peroxynitrite formation, NF- $\mathrm{KB}$ and AP-1 activation, and IL-8 gene expression in human leukocytes. Proc. Natl. Acad. Sci. USA 2002, 99, 13266-13271. [CrossRef] [PubMed] 
520. Nagaoka, I.; Tamura, H.; Hirata, M. An Antimicrobial Cathelicidin Peptide, Human CAP18/LL-37, Suppresses Neutrophil Apoptosis via the Activation of Formyl-Peptide Receptor-Like 1 and P2X 7. J. Immunol. 2006, 176, 3044-3052. [CrossRef]

521. Herrera, B.S.; Hasturk, H.; Kantarci, A.; Freire, M.O.; Nguyen, O.; Kansal, S.; van Dyke, T.E. Impact of resolvin $\mathrm{E} 1$ on murine neutrophil phagocytosis in type 2 diabetes. Infect. Immun. 2015, 83, 792-801. [CrossRef]

522. Freire, M.O.; Dalli, J.; Serhan, C.N.; Van Dyke, T.E. Neutrophil Resolvin E1 Receptor Expression and Function in Type 2 Diabetes. J. Immunol. 2017, 198, 718-728. [CrossRef]

523. Kurihara, T.; Jones, C.N.; Yu, Y.M.; Fischman, A.J.; Watada, S.; Tompkins, R.G.; Fagan, S.P.; Irimia, D. Resolvin D2 restores neutrophil directionality and improves survival after burns. FASEB J. 2013, 27, 2270-2281. [CrossRef]

524. Schwab, J.M.; Chiang, N.; Arita, M.; Serhan, C.N. Resolvin E1 and protectin D1 activate inflammation-resolution programmes. Nature 2007, 447, 869-874. [CrossRef]

525. Hsiao, H.-M.; Thatcher, T.H.; Levy, E.P.; Fulton, R.A.; Owens, K.M.; Phipps, R.P.; Sime, P.J. Resolvin D1 Attenuates Polyinosinic-Polycytidylic Acid-Induced Inflammatory Signaling in Human Airway Epithelial Cells via TAK1. J. Immunol. 2014, 193, 4980-4987. [CrossRef]

526. Ringholz, F.C.; Higgins, G.; Hatton, A.; Sassi, A.; Moukachar, A.; Fustero-Torre, C.; Hollenhorst, M.; Sermet-Gaudelus, I.; Harvey, B.J.; McNally, P.; et al. Resolvin D1 regulates epithelial ion transport and inflammation in cystic fibrosis airways. J. Cyst. Fibros. 2018, 17, 607-615. [CrossRef] [PubMed]

527. NCT03265288 Study of LAU-7b in the Treatment of Cystic Fibrosis in Adults-Full Text View-ClinicalTrials.gov. 2020. Available online: https://clinicaltrials.gov/show/NCT03265288 (accessed on 3 May 2020).

528. Kontoghiorghes, G.J.; Kontoghiorghe, C.N. Prospects for the introduction of targeted antioxidant drugs for the prevention and treatment of diseases related to free radical pathology. Expert Opin. Investig. Drugs 2019, 28, 593-603. [CrossRef]

529. Cantin, A.M. Low-hanging fruit and antioxidant therapy in cystic fibrosis. Am. J. Respir. Crit. Care Med. 2018, 198, 555-557. [CrossRef]

530. Calabrese, C.; Tosco, A.; Abete, P.; Carnovale, V.; Basile, C.; Magliocca, A.; Quattrucci, S.; De Sanctis, S.; Alatri, F.; Mazzarella, G.; et al. Randomized, single blind, controlled trial of inhaled glutathione vs placebo in patients with cystic fibrosis. J. Cyst. Fibros. 2015, 14, 203-210. [CrossRef] [PubMed]

531. Skov, M.; Pressler, T.; Lykkesfeldt, J.; Poulsen, H.E.; Jensen, P.Ø.; Johansen, H.K.; Qvist, T.; Kræmer, D.; Høiby, N.; Ciofu, O. The effect of short-term, high-dose oral $\mathrm{N}$-acetylcysteine treatment on oxidative stress markers in cystic fibrosis patients with chronic P. aeruginosa infection-A pilot study. J. Cyst. Fibros. 2015, 14, 211-218. [CrossRef] [PubMed]

532. Hector, A.; Griese, M.; Hartl, D. Oxidative stress in cystic fibrosis lung disease: An early event, but worth targeting? Eur. Respir. J. 2014, 44, 17-19. [CrossRef]

533. Griese, M.; Kappler, M.; Eismann, C.; Ballmann, M.; Junge, S.; Rietschel, E.; Van Koningsbruggen-Rietschel, S.; Staab, D.; Rolinck-Werninghaus, C.; Mellies, U.; et al. Inhalation treatment with glutathione in patients with cystic fibrosis: A randomized clinical trial. Am. J. Respir. Crit. Care Med. 2013, 188, 83-89. [CrossRef]

534. de Vries, J.J.V.; Chang, A.B.; Bonifant, C.M.; Shevill, E.; Marchant, J.M. Vitamin A and beta ( $\beta$ )-carotene supplementation for cystic fibrosis. Cochrane Database Syst. Rev. 2018, 2018, CD006751. [CrossRef]

535. González Jiménez, D.; Díaz Martín, J.J.; Arias Llorente, R.P.; Bousoño García, C. Oxidative Stress in Cystic Fibrosis. In Cystic Fibrosis in the Light of New Research; IntechOpen: London, UK, 2015.

536. Kontoghiorghe, C.N.; Kolnagou, A.; Kontoghiorghes, G.J. Antioxidant targeting by deferiprone in diseases related to oxidative damage. Front. Biosci. Landmark 2014, 19, 862-885. [CrossRef]

537. Kontoghiorghes, G.J. Prospects for introducing deferiprone as potent pharmaceutical antioxidant. Front. Biosci. Elit. 2009, 1, 161-178.

538. Conrad, C.; Lymp, J.; Thompson, V.; Dunn, C.; Davies, Z.; Chatfield, B.; Nichols, D.; Clancy, J.; Vender, R.; Egan, M.E.; et al. Long-term treatment with oral N-acetylcysteine: Affects lung function but not sputum inflammation in cystic fibrosis subjects. A phase II randomized placebo-controlled trial. J. Cyst. Fibros. 2015, 14, 219-227. [CrossRef] [PubMed]

539. Peters, S.A.; Kelly, F.J. Vitamin E supplementation in cystic fibrosis. J. Pediatr. Gastroenterol. Nutr. 1996, 22, 341-345. [CrossRef] [PubMed] 
540. Maqbool, A.; Stallings, V.A. Update on fat-soluble vitamins in cystic fibrosis. Curr. Opin. Pulm. Med. 2008, 14, 574-581. [CrossRef] [PubMed]

541. Galli, F.; Azzi, A. Present trends in vitamin E research. BioFactors 2010, 36, 33-42. [CrossRef]

542. Hamahata, A.; Enkhbaatar, P.; Kraft, E.R.; Lange, M.; Leonard, S.W.; Traber, M.G.; Cox, R.A.; Schmalstieg, F.C.; Hawkins, H.K.; Whorton, E.B.; et al. $\gamma$-Tocopherol nebulization by a lipid aerosolization device improves pulmonary function in sheep with burn and smoke inhalation injury. Free Radic. Biol. Med. 2008, 45, 425-433. [CrossRef]

543. Anais, J.P.; Razzouq, N.; Carvalho, M.; Fernandez, C.; Astier, A.; Paul, M.; Astier, A.; Fessi, H.; Lorino, A.M. Development of $\alpha$-tocopherol acetate nanoparticles: Influence of preparative processes. Drug Dev. Ind. Pharm. 2009, 35, 216-223. [CrossRef]

544. Rust, P.; Eichler, I.; Renner, S.; Elmadfa, I. Long-term oral $\beta$-carotene supplementation in patients with cystic fibrosis-Effects on antioxidative status and pulmonary function. Ann. Nutr. Metab. 2000, 44, 30-37. [CrossRef]

545. Sagel, S.D.; Sontag, M.K.; Anthony, M.M.; Emmett, P.; Papas, K.A. Effect of an antioxidant-rich multivitamin supplement in cystic fibrosis. J. Cyst. Fibros. 2011, 10, 31-36. [CrossRef]

546. Papas, K.A.; Sontag, M.K.; Pardee, C.; Sokol, R.J.; Sagel, S.D.; Accurso, F.J.; Wagener, J.S. A pilot study on the safety and efficacy of a novel antioxidant rich formulation in patients with cystic fibrosis. J. Cyst. Fibros. 2008, 7, 60-67. [CrossRef]

547. Sagel, S.D.; Khan, U.; Jain, R.; Graff, G.; Daines, C.L.; Dunitz, J.M.; Borowitz, D.; Orenstein, D.M.; Abdulhamid, I.; Noe, J.; et al. Effects of an antioxidant-enriched multivitamin in cystic fibrosis. Am. J. Respir. Crit. Care Med. 2018, 198, 639-647. [CrossRef]

548. Foucaud, P.; Therond, P.; Marchand, M.; Brion, F.; Demelier, J.F.; Navarro, J. Selenium and vitamin E in cystic fibrosis. Arch. Fr. Pediatr. 1988, 45, 383-386. [PubMed]

549. Tsavachidou, D.; McDonnell, T.J.; Wen, S.; Wang, X.; Vakar-Lopez, F.; Pisters, L.L.; Pettaway, C.A.; Wood, C.G.; Do, K.A.; Thall, P.F.; et al. Selenium and vitamin E: Cell type- and intervention-specific tissue effects in prostate cancer. J. Natl. Cancer Inst. 2009, 101, 306-320. [CrossRef] [PubMed]

550. Winklhofer-Roob, B.M.; Ellemunter, H.; Frühwirth, M.; Schlegel-Haueter, S.E.; Khoschsorur, G.; Van't Hof, M.A.; Shmerling, D.H. Plasma vitamin C concentrations in patients with cystic fibrosis: Evidence of associations with lung inflammation. Am. J. Clin. Nutr. 1997, 65, 1858-1866. [CrossRef] [PubMed]

551. Van Biervliet, S.; Vande Velde, S.; Van Biervliet, J.P.; Robberecht, E. The effect of zinc supplements in cystic fibrosis patients. Ann. Nutr. Metab. 2008, 52, 152-156. [CrossRef]

552. De Castro-Silva, C.; De Bruin, V.M.S.; Cunha, G.M.A.; Nunes, D.M.; Medeiros, C.A.M.; De Bruin, P.F.C. Melatonin improves sleep and reduces nitrite in the exhaled breath condensate in cystic fibrosis-A randomized, double-blind placebo-controlled study. J. Pineal Res. 2010, 48, 65-71. [CrossRef]

553. Moss, R.B.; Mayer-Hamblett, N.; Wagener, J.; Daines, C.; Hale, K.; Ahrens, R.; Gibson, R.L.; Anderson, P.; Retsch-Bogart, G.; Nasr, S.Z.; et al. Randomized, double-blind, placebo-controlled, dose-escalating study of aerosolized interferon gamma- $1 \mathrm{~b}$ in patients with mild to moderate cystic fibrosis lung disease. Pediatr. Pulmonol. 2005, 39, 209-218. [CrossRef]

554. Matsuse, T.; Teramoto, S.; Katayama, H.; Sudo, E.; Ekimoto, H.; Mitsuhashi, H.; Uejima, Y.; Fukuchi, Y.; Ouchi, Y. ICAM-1 mediates lung leukocyte recruitment but not pulmonary fibrosis in a murine model of bleomycin-induced lung injury. Eur. Respir. J. 1999, 13, 71-77. [CrossRef]

555. Ferretti, S.; Bonneau, O.; Dubois, G.R.; Jones, C.E.; Trifilieff, A. IL-17, Produced by Lymphocytes and Neutrophils, Is Necessary for Lipopolysaccharide-Induced Airway Neutrophilia: IL-15 as a Possible Trigger. J. Immunol. 2003, 170, 2106-2112. [CrossRef]

556. Ruan, H.; Pownall, H.J.; Lodish, H.F. Troglitazone antagonizes tumor necrosis factor- $\alpha$-induced reprogramming of adipocyte gene expression by inhibiting the transcriptional regulatory functions of NF-кB. J. Biol. Chem. 2003, 278, 28181-28192. [CrossRef]

557. Vanden Berghe, W.; Vermeulen, L.; Delerive, P.; De Bosscher, K.; Staels, B.; Haegeman, G. A paradigm for gene regulation: Inflammation, NF-кB and PPAR. Adv. Exp. Med. Biol. 2003, 544, 181-196.

558. Zingarelli, B.; Sheehan, M.; Hake, P.W.; O'Connor, M.; Denenberg, A.; Cook, J.A. Peroxisome Proliferator Activator Receptor- $\gamma$ Ligands, 15-Deoxy- $\Delta$ 12,14 -Prostaglandin J 2 and Ciglitazone, Reduce Systemic Inflammation in Polymicrobial Sepsis by Modulation of Signal Transduction Pathways. J. Immunol. 2003, 171, 6827-6837. [CrossRef] [PubMed] 
559. Perez, A.; Van Heeckeren, A.M.; Nichols, D.; Gupta, S.; Eastman, J.F.; Davis, P.B. Peroxisome proliferator-activated receptor- $\gamma$ in cystic fibrosis lung epithelium. Am. J. Physiol. Lung Cell. Mol. Physiol. 2008, 295, L303-L313. [CrossRef] [PubMed]

560. Dunzendorfer, S.; Rothbucher, D.; Schratzberger, P.; Reinisch, N.; Kähler, C.M.; Wiedermann, C.J. Mevalonate-dependent inhibition of transendothelial migration and chemotaxis of human peripheral blood neutrophils by pravastatin. Circ. Res. 1997, 81, 963-969. [CrossRef] [PubMed]

561. Rezaie-Majd, A.; Maca, T.; Bucek, R.A.; Valent, P.; Müller, M.R.; Husslein, P.; Kashanipour, A.; Minar, E.; Baghestanian, M. Simvastatin reduces expression of cytokines interleukin-6, interleukin- 8 , and monocyte chemoattractant protein-1 in circulating monocytes from hypercholesterolemic patients. Arterioscler. Thromb. Vasc. Biol. 2002, 22, 1194-1199. [CrossRef] [PubMed]

562. Zelvyte, I.; Dominaitiene, R.; Crisby, M.; Janciauskiene, S. Modulation of inflammatory mediators and PPAR $\gamma$ and NFKB expression by pravastatin in response to lipoproteins in human monocytes in vitro. Pharmacol. Res. 2002, 45, 147-154. [CrossRef] [PubMed]

563. Hopkins, N.; Gunning, Y.; O'Croinin, D.F.; Laffey, J.G.; McLoughlin, P. Anti-inflammatory effect of augmented nitric oxide production in chronic lung infection. J. Pathol. 2006, 209, 198-205. [CrossRef]

564. Watson, H.; Stackhouse, C. Omega-3 fatty acid supplementation for cystic fibrosis. Cochrane Database Syst. Rev. 2020, 2020, CD002201. [CrossRef]

565. Lee, M.; Kim, S.; Kwon, O.K.; Oh, S.R.; Lee, H.K.; Ahn, K. Anti-inflammatory and anti-asthmatic effects of resveratrol, a polyphenolic stilbene, in a mouse model of allergic asthma. Int. Immunopharmacol. 2009, 9, 418-424. [CrossRef]

566. Wood, L.G.; Wark, P.A.B.; Garg, M.L. Antioxidant and anti-inflammatory effects of resveratrol in airway disease. Antioxidants Redox Signal. 2010, 13, 1535-1548. [CrossRef]

567. Georgi, E.; Le Guellec, S.; Vecellio, L.; Fichant, E.; Stordeur, P.; Bordeau, P.; Perraudin, J. 68* Feasibility study of OSCN- and lactoferrin (Meveol $\left.{ }^{\circledR}\right)$ nebulization for cystic fibrosis patients. J. Cyst. Fibros. 2011, 10, S18. [CrossRef]

568. Chandler, J.D.; Min, E.; Huang, J.; McElroy, C.S.; Dickerhof, N.; Mocatta, T.; Fletcher, A.A.; Evans, C.M.; Liang, L.; Patel, M.; et al. Antiinflammatory and antimicrobial effects of thiocyanate in a cystic fibrosis mouse model. Am. J. Respir. Cell Mol. Biol. 2015, 53, 193-205. [CrossRef] [PubMed]

569. Xiao, H.; Parkin, K.L. Induction of phase II enzyme activity by various selenium compounds. Nutr. Cancer 2006, 55, 210-223. [CrossRef] [PubMed]

570. Galli, F. Interactions of Polyphenolic Compounds with Drug Disposition and Metabolism. Curr. Drug Metab. 2007, 8, 830-838. [CrossRef] [PubMed]

571. Van Goor, F.; Hadida, S.; Grootenhuis, P.D.J.; Burton, B.; Cao, D.; Neuberger, T.; Turnbull, A.; Singh, A.; Joubran, J.; Hazlewood, A.; et al. Rescue of CF airway epithelial cell function in vitro by a CFTR potentiator, VX-770. Proc. Natl. Acad. Sci. USA 2009, 106, 18825-18830. [CrossRef] [PubMed]

Publisher's Note: MDPI stays neutral with regard to jurisdictional claims in published maps and institutional affiliations.

(C) 2020 by the authors. Licensee MDPI, Basel, Switzerland. This article is an open access article distributed under the terms and conditions of the Creative Commons Attribution (CC BY) license (http://creativecommons.org/licenses/by/4.0/). 